UNIVERSIDADE DE SÃO PAULO

ESCOLA DE ENGENHARIA DE LORENA

BIANCA OLIVA

Expressão heteróloga, caracterização bioquímica e avaliação da suplementação da enzima oxidativa Celobiose Desidrogenase na sacarificação da biomassa 

BIANCA OLIVA

Expressão heteróloga, caracterização bioquímica e avaliação da suplementação da enzima oxidativa Celobiose Desidrogenase na sacarificação da biomassa

Dissertação apresentada à Escola de Engenharia de Lorena da Universidade de São Paulo para a obtenção do título de Mestre em Ciências do Programa de Pós-Graduação em Biotecnologia Industrial na área de Microbiologia Aplicada

Orientador: Prof. Dr. Fernando Segato

Versão Corrigida

Lorena

2019 
AUTORIZO A REPRODUÇÃO E DIVULGAÇÃO TOTAL OU PARCIAL DESTE TRABALHO, POR QUALQUER MEIO CONVENCIONAL OU ELETRÔNICO, PARA FINS DE ESTUDO E PESQUISA, DESDE QUE CITADA A FONTE

Ficha catalográfica elaborada pelo Sistema Automatizado da Escola de Engenharia de Lorena, com os dados fornecidos pelo(a) autor(a)

\section{Oliva, Bianca}

Expressão heteróloga, caracterização bioquímica e avaliação da suplementação da enzima oxidativa Celobiose Desidrogenase na sacarificação da biomassa / Bianca Oliva; orientador Fernando Segato - Versão Corrigida. - Lorena, 2019.

$93 \mathrm{p}$.

Dissertação (Mestrado em Ciências - Programa de Pós Graduação em Biotecnologia Industrial na Área de Microbiologia Aplicada) - Escola de Engenharia de Lorena da Universidade de São Paulo. 2019

1. Celobiose desidrogenase. 2. Myceliophthora thermophila. 3. Expressão heteróloga. 4.

Sacarificação. 5. Biomassa. I. Título. II. Segato, Fernando, orient. 
Dedico este trabalho à Deus e a minha família, por todo amor e carinho que recebi durante a elaboração desse trabalho. 



\section{AGRADECIMENTOS}

À Deus por ser essencial em minha vida.

Ao orientador Prof. Dr. Fernando Segato, por todo o empenho dedicado à elaboração deste trabalho, por todas as palavras de incentivo e minha gratidão por compartilhar sua sabedoria, o seu tempo e sua experiência.

Aos meus pais Robson e Silvia e a minha irmã Vanessa, pelo amor, incentivo, apoio incondicional, amizade, paciência e por serem meus modelos de coragem e dedicação.

Ao meu grande amor, Augusto, por estar comigo todos os dias, me apoiando, me fortalecendo e fazendo meus dias ficarem ainda melhores e mais cheios de amor.

Meus agradecimentos aos meus amigos Josman, Awana, Gislene, Aline, Bruno e a todos os companheiros de laboratório pela amizade e companheirismo e por fazerem parte da minha formação.

A Universidade de São Paulo e ao Departamento de Biotecnologia Industrial, pela oportunidade de realizar o curso.

Às Agências de fomento CAPES, CNPq, FAPESP por financiarem o meu trabalho e incentivarem a oportunidade de eu poder fazer o que amo. 



\section{RESUMO}

OLIVA, B. Expressão heteróloga, caracterização bioquímica e avaliação da suplementação da enzima oxidativa Celobiose Desidrogenase na sacarificação da biomassa. 2019. 93 p. Dissertação (Mestrado em Ciências) - Escola de Engenharia de Lorena, Universidade de São Paulo, Lorena, 2019.

A produção de biocombustíveis e a obtenção de alguns compostos químicos a partir de materiais renováveis, como a biomassa lignocelulósica, ainda não são processos triviais, principalmente devido a recalcitrância destes materiais. Estudos recentes reconheceram as enzimas acessórias, como xilanases e enzimas com Atividade Auxiliar, como potencializadores da atividade de celulases no processo de despolimerização da lignocelulose. A prospecção de enzimas com características termoestáveis é vantajosa para este tipo de aplicação e além disso, estudos sobre o secretoma de diversos fungos cultivados em biomassa como fonte de carbono, tem encontrado enzimas com mecanismo oxidativo, dentre eles, o fungo termofílico Myceliophthora thermophila M77. Porém, estas enzimas tem sido pouco estudadas quanto a sua aplicação na sacarificação da biomassa. Sendo assim, este trabalho visou a expressão heteróloga, a caracterização bioquímica e a ação da enzima oxidativa celobiose desidrogenase do fungo M. thermophila (M77CDH) em conjunto com outras celulases no processo de sacarificação da biomassa. Pela análise filogenética a M77CDH prospectada foi classificada como pertencente a Classe IIB das CDHs. O gene que codifica esta enzima foi clonado no vetor pEXPYR e heterólogamente expresso em $A$. nidulans. A proteína recombinante $\mathrm{M} 77 \mathrm{CDH}$ foi purificada e teve sua identidade confirmada por espectrometria de massas. Nas análises bioquímicas, apresentou atividade ótima a $65^{\circ} \mathrm{C}$ e reteve mais de $80 \%$ da sua atividade a $50{ }^{\circ} \mathrm{C}$ por 2 horas e pela análise de dicroísmo circular apresentou um desenovelamento da sua estrutura na temperatura de transição de $62,8{ }^{\circ} \mathrm{C}$. Apresentou mais de $80 \%$ de atividade em uma faixa ampla de $\mathrm{pH}$ (4,5 - 9), em que o domínio citocromo mostrou maior afinidade em $\mathrm{pHs}$ alcalinos, característica incomum entre as CDHs descritas na literatura. A atividade da $\mathrm{M} 77 \mathrm{CDH}$ foi ligeiramente aumentada pela adição de $\mathrm{MgCl}_{2}$ e $\mathrm{Na}_{2} \mathrm{MoO}_{4}$ e altamente afetada por $\mathrm{CuSO}_{4}$ e $\mathrm{FeCl}_{3}$. A eficiência catalítica $\left(\mathrm{k}_{\mathrm{cat}} / \mathrm{k}_{\mathrm{m}}=266 \mathrm{mM}^{-1} \mathrm{~s}^{-1}\right)$ utilizando celobiose foi bastante similar aos valores indicados por CDHs da Classe IIA. O envelope da M77CDH gerado por SAXS foi satisfatório e conveniente com a literatura. $\mathrm{Na}$ sacarificação de bagaço de cana pré-tratado hidrotermicamente, utilizando coquetel de A. niveus suplementado com M77CDH, foi possível observar que a adição de $\mathrm{M} 77 \mathrm{CDH}$ modificou o perfil de produtos liberados na desconstrução da biomassa. Por fim, na sacarificação do PASC observou-se a sacarificação e produção de ácido celobiônico.

Palavras-chave: Celobiose Desidrogenase. Myceliophthora thermophila. Expressão heteróloga. Caracterização. Sacarificação. Biomassa. 


\begin{abstract}
OLIVA, B. Heterologous production, biochemical characterization and evaluation of oxidative enzyme Cellobiose Dehydrogenase in saccharification of biomass. 2019. 93p. Dissertation (Master of Science) - Escola de Engenharia de Lorena, Universidade de São Paulo, Lorena, 2019.
\end{abstract}

The production of biofuels and chemicals from renewable materials such as lignocellulosic biomass are non-trivial processes mainly due to the recalcitrance of the material. Recent studies have recognized accessory enzymes such as xylanases and Auxiliary Activity enzymes as potentiators in cellulase activity during the depolymerization of lignocellulose. The prospection of thermostable enzymes can be an advantage the improve the depolymerization of these materials. In addition, several enzymes showing oxidative mode of action were found in the secretoma of the thermophilic fungus Myceliophthora thermophila strain M77. However, these enzymes are poor studied regarding their application in biomass saccharification. Therefore, this project aimed the heterologous expression and biochemical characterization of the oxidative enzyme cellobiose dehydrogenase of the fungus $M$. thermophila $(\mathrm{M} 77 \mathrm{CDH})$. By phylogenetic analysis the M77CDH was classified as belonging to Class IIB of CDHs. The gene encoding this enzyme was cloned and heterologously expressed in A. nidulans, the M77CDH was purified and had its identity confirmed by mass spectrometry. In the biochemical analyzes the M77CDH showed an optimum activity at $65^{\circ} \mathrm{C}$ and retained more than $80 \%$ of its activity at $50{ }^{\circ} \mathrm{C}$ for 2 hours. The circular dichroism analysis showed a denaturation of its structure at the transition temperature of $62.8^{\circ} \mathrm{C}$. M77CDH also kept more than $80 \%$ of its activity in a wide $\mathrm{pH}$ range (4.5 - 9), in which the cytochrome domain showed higher affinity at alkaline $\mathrm{pH}$, an unusual behavior compared with other CDHs described in the literature. The activity of $\mathrm{M} 77 \mathrm{CDH}$ was increased slightly in the presence of $\mathrm{MgCl}_{2}$ and $\mathrm{Na}_{2} \mathrm{MoO}_{4}$ and was highly affected by $\mathrm{CuSO}_{4}$ and $\mathrm{FeCl}_{3}$. The catalytic efficiency $\left(\mathrm{k}_{\mathrm{cat}} / \mathrm{k}_{\mathrm{m}}=266 \mathrm{mM}^{-1} \mathrm{~s}^{-1}\right)$ in cellobiose was quite similar to the values indicated by CDHs from Class IIA. The envelope of M77CDH generated by SAXS was satisfactory and convenient with the literature. In saccharification of sugarcane bagasse hydrothermally pretreated using $A$. niveus cocktail supplemented with M77CDH was possible to observe the addition of M77CDH modified the profile of released products in the deconstruction of the biomass. Finally, in the action on PASC was observed the saccharification and production of cellobionic acid.

Keywords: Cellobiose Dehydrogenase. Myceliophthora thermophila. Heterologous expression. Characterization. Saccharification. Biomass. 


\section{LISTA DE FIGURAS}

Figura 1 - Esquema dos tipos de enzimas envolvidas na hidrólise da celulose.

Figura 2 - Oxidação do substrato pela ação da $\mathrm{CDH}$.

Figura 3 - Estrutura tridimensional da $\mathrm{CDH}$ em suas diferentes conformações.

Figura 4 - Esquema da ação catalítica da CDH na oxidação do substrato e da interação da $\mathrm{CDH}$ com os diferentes tipos de aceptores de elétrons e os estados de oxidação de cada cofator flavina e heme $b$.

Figura 5 - Esquema das possíveis funções da $\mathrm{CDH}$ durante a despolimerização da lignocelulose.

Figura 6 - Esquematização das reações típicas na lignina realizadas pelo radical hidroxila.

Figura 7 - Mecanismo da reação da LPMO (PMO) em celulose e função da CDH em cooperação com LPMO.

Figura 8 - Ciclo catalítico da lignina peroxidase utilizando peróxido de hidrogênio como insumo para oxidar e formar radical de seu substrato, no caso representado pelo álcool veratrílico.

Figura 9 - Funções da CDH in vivo auxiliando a ação da MnP.

Figura 10 - Esquema representando regiões do vetor pEXPYR 42

Figura 11 - Esquema identificando as regiões de peptídeo sinal (sp), linker e os domínios CYT e DH da M77CDH.

Figura 12 - Alinhamento entre as sequências de aminoácidos da $\mathrm{M} 77 \mathrm{CDH}$ e $M t \mathrm{CDH}(M$. thermophilum).

Figura 13 - Análise filogenética de 34 sequências de CDHs de vários fungos, incluindo basidiomicetos e ascomicetos. 56

Figura 14 - Géis referentes às etapas de clonagem e expressão da M77CDH. 57

Figura 15 - Resultado do espectrômetro de massas da banda excisada do gel referente a $\mathrm{M} 77 \mathrm{CDH}$.

Figura 16 - Géis de SDS-PAGE e cromatogramas referentes às etapas de troca iônica e gel filtração de purificação da proteína $\mathrm{M} 77 \mathrm{CDH}$.

Figura 17 - Géis de SDS-PAGE do teste de desglicosilação. 
Figura 18 - Espectro UV-Visível da forma oxidada e reduzida da M77CDH.

Figura 19 - Influência do pH na atividade e na estabilidade da M77CDH. .62

Figura 20 - Influência da temperatura na atividade e na estabilidade da M77CDH. .64

Figura 21 - Dicroísmo circular e espectro da desnaturação térmica da M77CDH. .65

Figura 22 - Efeito dos compostos $\mathrm{MgCl}_{2}$ e $\mathrm{Na}_{2} \mathrm{MoO}_{4}$ em diferentes concentrações na atividade enzimática da M77CDH.

Figura 23 - Efeito dos compostos $\mathrm{CuSO}_{4}$ e $\mathrm{FeCl}_{3}$ em diferentes concentrações na atividade enzimática da M77CDH.

Figura 24 - Consumo de celobiose e produção de ácido celobiônico ao longo do tempo de reação. .70

Figura 25 - Atividade relativa nos diferentes tipos de celooligossacarídeos. .71

Figura 26 - Análise do envelope da M77CDH por SAXS. .72

Figura 27 - Análise do total de açúcares redutores liberados com a hidrólise do bagaço de cana pré-tratado. 74

Figura 28 - Via hidrolítica ou oxidativa para a clivagem da celobiose. .74

Figura 29 - Sacarificação do PASC pelo coquetel comercial Celluclast ${ }^{\circledR}$ suplementado com LPMO bacteriana e M77CDH. .76

Figura 30 - Alinhamento das sequências de aminoácidos das CDHs que apresentaram maior similaridade com a M77CDH. 87

Figura 31 - Curvas de cinética enzimática da M77CDH utilizando celobiose como substrato e DCIP. .88

Figura 32 - Curvas exemplificando a metodologia utilizada para calcular a atividade enzimática da M77CDH. .90

Figura 33 - Curvas padrão utilizadas no trabalho. .91

Figura 34 - Estrutura do FAD e heme b (ou haem b) e suas respectivas localizações nos domínios DH e CYT. 


\section{LISTA DE TABELAS}

Tabela 1 - CDHs de vários fungos clonadas até o momento, indicando o organismo de

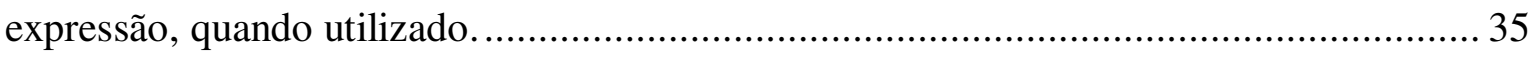

Tabela 2 - Parâmetros utilizados na reação de PCR para amplificação gênica. ................. 42

Tabela 3 - Efeito de vários íons e solventes na atividade enzimática da M77CDH. ......... 66

Tabela 4 - Parâmetros cinéticos aparentes para DCIP e cyt c como aceptores de elétrons. 68

Tabela 5 - Constantes cinéticas aparentes para carboidratos, como doadores de elétrons,

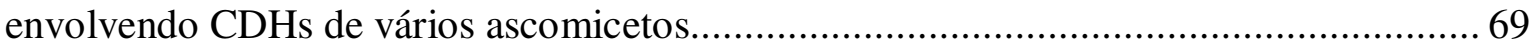

Tabela 6 - Dados das sequências de aminoácidos codificando diversas CDHs utilizadas na

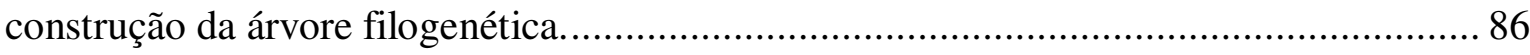





\section{LISTA DE ABREVIATURAS E SIGLAS}

\begin{tabular}{|c|c|}
\hline AA & Atividade Auxiliar \\
\hline BLAST & Basic Local Alignment Tool \\
\hline $\mathrm{BG}$ & Beta-glicosidase \\
\hline CAZy & Carbohydrate-Active Enzymes \\
\hline $\mathrm{CBM}$ & Carbohydrate-binding module \\
\hline $\mathrm{CDH}$ & Celobiose desidrogenase \\
\hline $\mathrm{CBH}$ & Celobiohidrolase \\
\hline DNA & Deoxyribonucleic acid \\
\hline DNS & Ácido dinitrosalicílico \\
\hline DSPS & Double strength protoplasting solution \\
\hline $\mathrm{EC}$ & Enzyme comission \\
\hline EDTA & Ethylenediamine tetraacetic acid \\
\hline EG & Endoglucanase \\
\hline $\mathrm{g}$ & Grama \\
\hline GH & Glicosil Hidrolase \\
\hline HPLC & High Performance Liquid Chromatography \\
\hline HPAEC & High-Performance Anion-Exchange Chromatography \\
\hline${ }^{\circ} \mathrm{C}$ & Graus centígrados \\
\hline ID & Identification number \\
\hline $\mathrm{kb}$ & Kilobases \\
\hline $\mathrm{k}_{\text {cat }}$ & Turn over number \\
\hline $\mathrm{Kg}$ & Kilogramas \\
\hline $\mathrm{kDa}$ & Kilodalton \\
\hline $\mathrm{k}_{\mathrm{m}}$ & Constante de Michaelis-Menten \\
\hline 1 & Litros \\
\hline LB & Luria-Bertani \\
\hline UV & Ultravioleta \\
\hline $\mathrm{MPa}$ & Megapascal \\
\hline MM & Meio Mínimo \\
\hline $\mathrm{ml}$ & Mililitro \\
\hline$\mu 1$ & Microlitro \\
\hline
\end{tabular}




$\begin{array}{ll}\mathrm{mg} & \text { Miligramas } \\ \mathrm{mM} & \text { Milimolar } \\ \mathrm{NCBI} & \text { National Center for Biotechnology Information } \\ \mathrm{ng} & \text { Nanograma } \\ \mathrm{PASC} & \text { Phosporic Acid Swollen Celulose } \\ \mathrm{pb} & \text { Pares de base } \\ \mathrm{PCR} & \text { Polimerase Chain Reaction } \\ \mathrm{PEG} & \text { Polietilenoglicol } \\ p^{\mathrm{P}} & \text { Gene que codifica a orotidina-5'-monofosfato descarboxilase de A. } \\ \mathrm{H}_{2} \mathrm{O}_{2} & \text { niger } \\ \mathrm{PDB} & \text { Peróxido de hidrogênio } \\ \mathrm{PCR} & \text { Protein Data Bank } \\ \mathrm{pH} & \text { Polymerase Chain Reaction } \\ \mathrm{rpm} & \text { Potencial hidrogeniônico } \\ \mathrm{SDS}-\mathrm{PAGE} & \text { Rotações por minuto } \\ \mathrm{T}_{\mathrm{m}} & \text { Tedium Dodecyl Sulfate Polyacrylamide Gel Eletrophoresis } \\ \mathrm{USP} & \text { Universidade de São Paulo }\end{array}$




\section{SUMÁRIO}

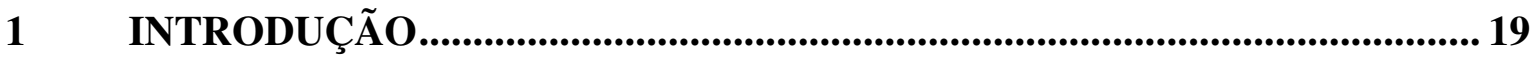

2 REVISÃO BIBLIOGRÁFICA ....................................................................... 20

2.1 Degradação da biomassa por enzimas hidrolíticas ................................................ 20

2.2 Degradação da biomassa incluindo enzimas oxidativas ...................................... 22

2.3 Família de enzimas com Atividade Auxiliar (AA3) ........................................... 23

2.3.1 Celobiose desidrogenase (CDH) ...............................................................23

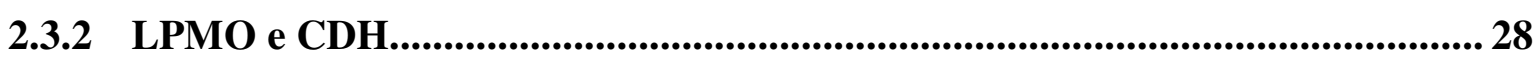

2.4 Enzimas oxidativas degradadoras de lignina ............................................... 30

2.4.1 Lignina Peroxidase (LiP) e CDH ........................................................................... 31

2.4.2 Manganês Peroxidase (MnP) e CDH...................................................................... 32

2.5 Fungos termofílicos e enzimas termoestáveis................................................ 33

2.6 CDH e tecnologia do DNA recombinante...................................................... 34

2.7 Classificação das CDHS................................................................................... 36

2.8 Expressão da celobiose desidrogenase (M77CDH) em A. nidulans A773 ........ 36

2.9 Aplicações dos ácidos aldônicos de oligossacarídeos ....................................... 38

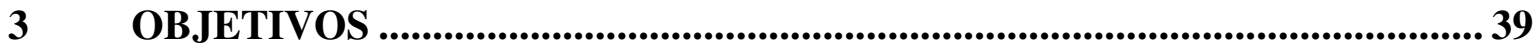

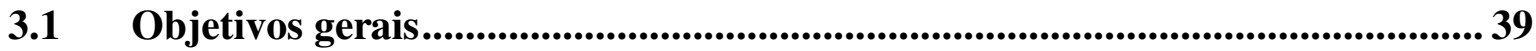

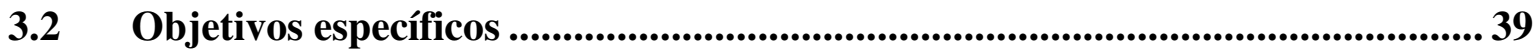

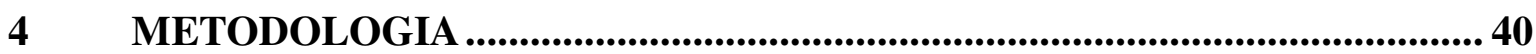

4.1 Linhagens dos fungos utilizados ............................................................... 40

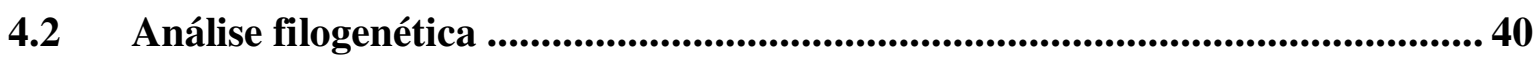

4.3 Clonagem, expressão e secreção da M77CDH .................................................. 41

4.3.1 Construção dos oligonucleotídeos....................................................................... 41

4.3.2 Extração do DNA genômico ..................................................................................... 41

4.3.3 Amplificação do gene codificando M77CDH e do vetor pEXPYR................... 41

4.3.4 Construção dos plasmídeos............................................................................................. 43

4.3.5 Transformação bacteriana ....................................................................................... 43

4.3.6 Purificação dos plasmídeos ............................................................................. 43

4.3.7 Preparação de protoplastos ................................................................................ 44

4.3.8 Transformação dos protoplastos mediado por PEG ....................................... 44

4.3.9 Screening das colônias transformantes de $A$. nidulans ....................................... 45 
4.4 Cultivo do transformante de $A$. nidulans para expressão da proteína de interesse

4.5 Confirmação da proteína por Espectrometria de Massas ...............................45

4.6 Purificação enzimática........................................................................................46

4.7 Caracterização espectral ..........................................................................................46

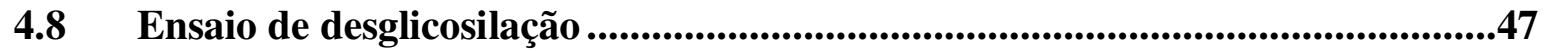

4.9 Ensaios para caracterização bioquímica......................................................47

4.9.1 Atividade enzimática ...................................................................................47

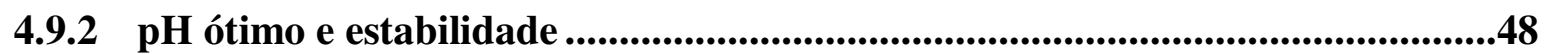

4.9.3 Temperatura ótima e estabilidade térmica ..................................................48

4.9.4 Painel de íons e componentes químicos.........................................................49

4.9.5 Cinética enzimática da M77CDH.................................................................49

4.9.6 Reação com celobiose e celooligossacarídeos ................................................50

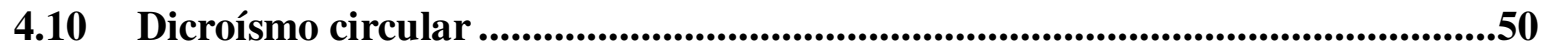

4.11 Espalhamento de Raios-X a baixos ângulos (SAXS) ...................................51

4.12 Sacarificação enzimática da biomassa utilizando extrato bruto de $A$. niveus suplementado com M77CDH ....................................................................51

4.12.1 Bagaço de cana pré-tratado por Liquid Hot Water ......................................51

4.12.2 Obtenção do extrato enzimático de A. niveus RP-40 .....................................51

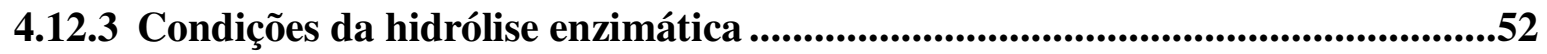

4.13 Sacarificação enzimática do PASC utilizando coquetel comercial suplementado com LPMO e M77CDH ........................................................................................52

5 RESULTADOS E DISCUSSÃO ..............................................................53

5.1 Análise da sequência da M77CDH.........................................................53

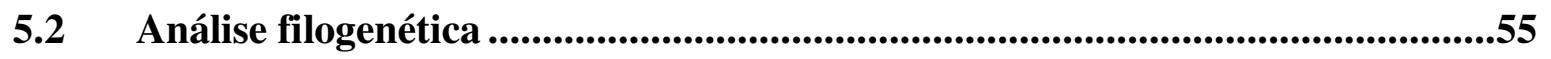

5.3 Clonagem e expressão da M77CDH e confirmação da proteína por Espectrometria de Massas (LC-MS/MS) ..................................................................56

5.4 Purificação enzimática...........................................................................................58

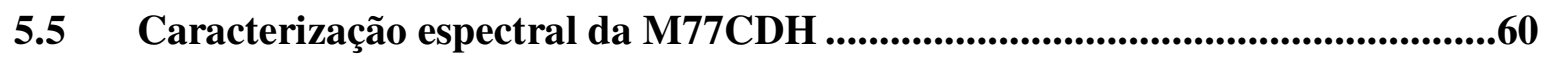

5.6 Caracterização bioquímica da M77CDH...............................................61

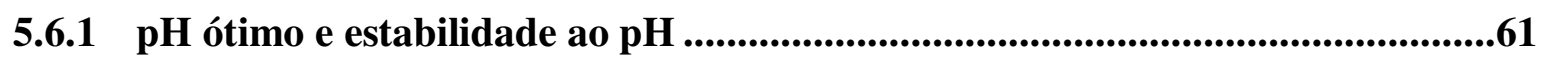

5.6.2 Temperatura ótima e estabilidade térmica ...............................................63

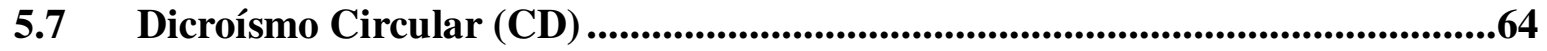

5.8 Influência de íons e compostos químicos na atividade da M77CDH ................65 
5.9 Determinação dos parâmetros cinéticos................................................................. 68

5.10 Reação com celobiose e celooligossacarídeos ..................................................... 69

5.11 Espalhamento de Raios-X a baixo ângulo (SAXS)......................................... 71

5.12 Ação do extrato bruto de A. niveus suplementado com M77CDH em bagaço de cana pré-tratado......................................................................................... 73

5.13 Ação de celulases suplementado com LPMO e M77CDH em PASC ................ 75

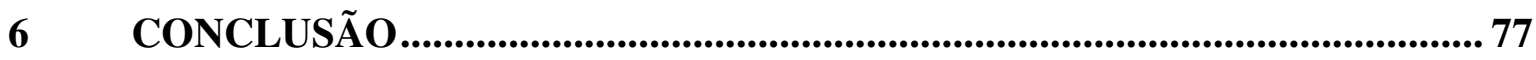

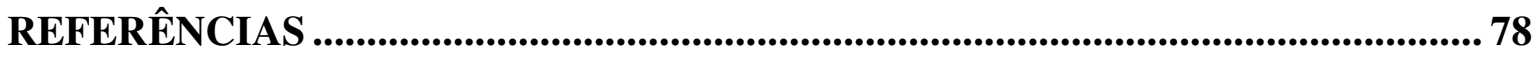

APÊNDICE A ........................................................................................................ 86

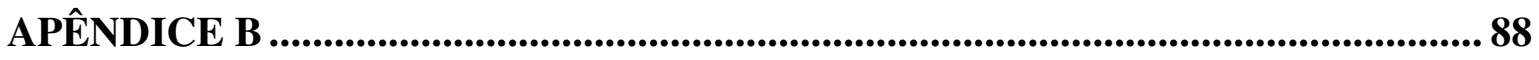

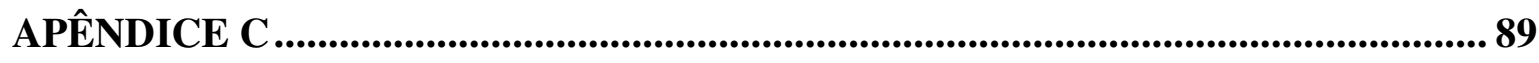

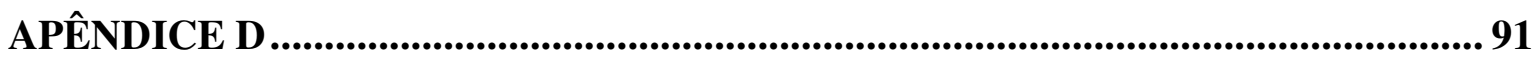

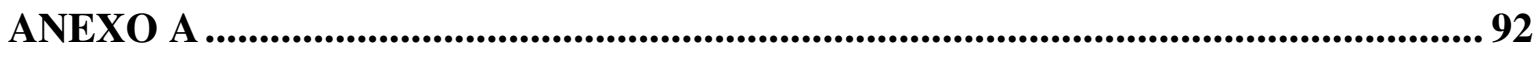

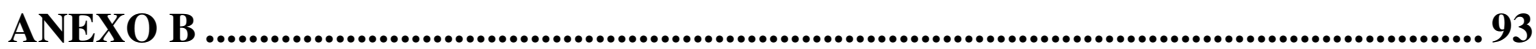





\section{INTRODUÇÃO}

A produção de combustíveis e outros compostos químicos a partir de fontes renováveis, de baixo custo e disponíveis em grandes quantidades é o cenário mais promissor para um futuro sustentável. A biomassa, principalmente, o bagaço de cana, cumpre todos os requisitos necessários, pois na indústria após a moagem e extração do caldo, o bagaço resultante (que representa aproximadamente $25 \%$ do peso total) contém ainda entre 60 a $80 \%$ de carboidratos em sua composição. Somado a isso, as folhas e o topo da planta, que atualmente são deixados no campo, resultam em cerca de 1/3 da produção de cana-de-açúcar que se tornam "subutilizados". Com a queima deste bagaço nas usinas para a cogeração de energia elétrica, a maior parte do potencial energético da cana é perdido, finalizando o uso desse material com um descarte poluente e ineficiente do ponto de vista energético (SOCCOL et al., 2010).

Contudo, a desconstrução da biomassa para geração de monômeros ainda é bastante dificultada pela recalcitrância deste material, a qual é principalmente causada pela celulose cristalina e pela presença da lignina na parede celular vegetal. Essa resistência pode ser diminuída por processos que envolvem condições severas de operação, como dispendiosos pré-tratamentos físico-químicos, altas pressões e altas temperaturas. Após essa etapa, a biomassa residual pode ser utilizada em processos de sacarificação enzimáticas que operam em temperaturas amenas, pressão atmosférica e com enzimas com ação específica, que geram os açúcares de interesse (REZENDE et al., 2011; SOCCOL et al., 2010). Os preparos enzimáticos comerciais englobam basicamente enzimas com mecanismos hidrolíticos, porém, ainda é necessária uma elevada carga enzimática para uma eficiente hidrólise, o que torna o processo altamente custoso. Além disso, os coquetéis enzimáticos não são muito eficientes para degradar os elementos recalcitrantes. Com a descoberta da importância das enzimas oxidativas esse cenário vem sendo modificado, pois essa classe de enzimas auxilia as enzimas hidrolíticas, promovendo maior acesso ao substrato (VAAJE-KOLSTAD et al., 2010). O presente trabalho avaliou a enzima oxidativa celobiose desidrogenase como agente potencializador na degradação da biomassa, auxiliando as enzimas dos complexos celulolítico, ligninolítico e xilanolítico. 


\section{REVISÃO BIBLIOGRÁFICA}

\subsection{Degradação da biomassa por enzimas hidrolíticas}

A estrutura da biomassa lignocelulósica é composta por fibras de celulose embebidas em hemicelulose e lignina. Os polissacarídeos celulose e hemicelulose formam uma rede em torno da célula vegetal, com a lignina preenchendo o material como um "cimento", sendo localizado nos espaços existentes nesta rede (FAN et al., 2012). O modelo clássico de degradação do componente mais abundante da biomassa, a celulose, envolve o sinergismo entre as enzimas conhecidas como celulases, as quais são classificadas em três grupos: endo1,4- $\beta$-glucanase (endoglucanase), exo-1,4- $\beta$-glucanase (celobiohidrolase) e $\beta$-glicosidase (Figura 1).

As endoglucanases (EG, EC 3.2.1.4) agem nas regiões amorfas da cadeia de celulose de forma aleatória. A principal importância da EG é reduzir o grau de polimerização da celulose e, por consequência, aumentar o nível de extremidades reativas que serão alvo para a ação das celobiohidrolases (PAYNE et al., 2015).

As celobiohidrolases (CBHI, EC 3.2.1.176 e CBHII, EC 3.2.1.91) estão entre as enzimas mais estudadas e importantes na desconstrução da celulose. Estas enzimas, necessitam de extremidades (redutoras e não-redutoras para as enzimas CBHI e CBHII, respectivamente) na cadeia de celulose para se ligar, pois, sua estrutura em forma de túnel possibilita a ação das CBHs em uma única cadeia de celulose por vez. Os produtos liberados pela sua ação são tipicamente dissacarídeos solúveis (celobiose), que são substratos para a $\beta$-glicosidase (PAYNE et al., 2015; VÁRNAI et al., 2014) .

As $\beta$-glicosidases (BG, EC 3.2.1.21) hidrolisam resíduos de $\beta$-D-glicosil presentes na extremidade não redutora de celobiose. O produto final da reação são unidades de $\beta$-Dglicose. A BG é um agente chave para uma eficiente hidrólise, pois atua diminuindo o acúmulo de celobiose, prevenindo a inibição da CBH e EG pela celobiose (PAYNE et al., 2015; SØRENSEN et al., 2013).

Um coquetel de enzimas hidrolíticas também é necessário para a eficiente hidrólise da hemicelulose (DE VRIES et al., 2000). A hemicelulose mais abundante na natureza é a xilana, sendo necessário um coquetel que deve englobar a atividade conjunta de enzimas como as endo-1,4- $\beta$-D-xilanases (EC 3.2.1.8) e as 1,4- $\beta$-D-xilosidases (EC 3.2.1.37) para a despolimerização da cadeia principal (ZAMOST; NIELSEN; STARNES, 1991). As xilanases clivam ligações $\beta(1 \rightarrow 4)$ da cadeia principal resultando na diminuição do grau de polimerização da xilana (DODD; CANN, 2009; KOLENOVA; VRSANSKA; BIELY, 
2006). O produto gerado pela ação das xilanases são alvos para as $\beta$-xilosidases, que são capazes de agir em resíduos de xilobiose e nas extremidades redutoras de xilooligossacarídeos curtos, liberando o monômero xilose (POLIZELI et al., 2005).

As ramificações das cadeias da hemicelulose são clivadas por enzimas específicas, que atuam de acordo com o resíduo de açúcar em questão. Logo, podem ser requeridas enzimas como $\alpha$-L-arabinofuranosidases (EC 3.2.1.55), que retiram grupos de $\alpha$-Larabinofuranosil; $\alpha$-D-glucuronidases (EC 3.2.1.139), que agem especificamente nas ligação 4-O-metil-éster entre xilose e ácido glucurônico; acetil xilana esterases (EC 3.1.1.72) as quais clivam ligações entre xilose/ácido acético e xilose/ácido ferúlico; além de endo-1,4- $\beta$ mananases (EC 3.2.1.78) e 1,4- $\beta$-manosidases (EC 3.2.1.25) podem ser requeridas no processo (SHALLOM; SHOHAM, 2003). Portanto, vários tipos de enzimas devem atuar sinergicamente para realizar a hidrólise da cadeia principal da hemicelulose e de seus grupos pendentes.

Figura 1 - Esquema dos tipos de enzimas envolvidas na hidrólise da celulose.

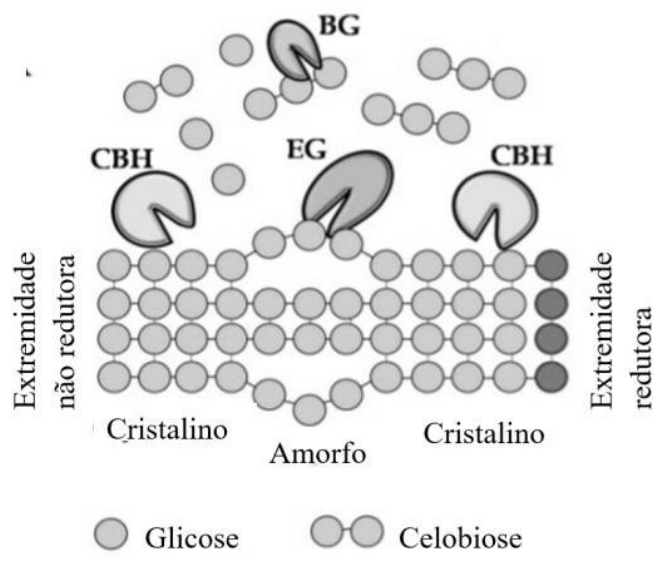

Fonte: Adaptado de (RATANAKHANOKCHAI et al., 2013).

Nota: CBH: Celobiohidrolases clivam a glicose em unidades de celobiose a partir da extremidade não redutora e redutora da cadeia de celulose.

EG: Endoglucanases agem internamente na celulose e preferencialmente nas regiões amorfas, em que o substrato é mais acessível, liberando oligossacarídeos de tamanhos intermediários.

BG: a $\beta$-glicosidase hidrolisa as unidades de celobiose em glicose.

Os preparos comerciais utilizados na despolimerização da biomassa, são principalmente compostos pelas enzimas mencionadas anteriormente, sendo importante ressaltar que todas apresentam mecanismos hidrolítico, ou seja, agem juntamente com uma molécula de água para clivar as ligações glicosídicas dos polissacarídeos. 
A competitividade de um produto no mercado pode ser diretamente relacionada ao rendimento obtido em cada etapa do processo utilizado para sua produção. Logo, a consolidação de biocombustíveis a partir da celulose (no caso, o bioetanol 2G) é bastante dependente, entre outros aspectos, da eficiência e rapidez da etapa de hidrólise enzimática. O estudo de Eijink et al (2008) observou que, apesar de enzimas processivas como as celobiohidrolases, melhorarem a acessibilidade de outras enzimas à celulose, estas apresentam velocidade relativamente baixa. Logo, uma abordagem diferente nos coquetéis enzimáticos, através da inserção de uma maior proporção de enzimas com atuação nãoprocessiva na celulose cristalina, como por exemplo enzimas acessórias, poderia contribuir para uma hidrólise enzimática mais eficiente (EIJSINK et al., 2008; HORN et al., 2006, 2012).

\subsection{Degradação da biomassa incluindo enzimas oxidativas}

Até recentemente, toda a atenção foi dada a utilização de celulases como estratégia de se obter uma maior eficiência na hidrólise enzimática, pois estas são responsáveis por degradar o polissacarídeo mais abundante contido nos materiais lignocelulósicos. Teoricamente, as enzimas hidrolíticas seriam suficientes para degradar toda a celulose, contudo, a porção cristalina da celulose é desconstruída parcialmente, de forma lenta e incompleta pelas celulases (MORGENSTERN; POWLOWSKI; TSANG, 2014). Muitos autores já questionavam, que o modelo clássico de hidrólise da biomassa, e principalmente, da celulose era muito simples, indicando que poderia estar incompleto. Na segunda metade do século XX, Reese, Siu e Levinson (1950) sugeriram que poderiam haver componentes não-hidrolíticos auxiliando na desconstrução da celulose cristalina, promovendo desta maneira um aumento da acessibilidade das enzimas hidrolíticas. Estudos recentes reconheceram as enzimas auxiliares e acessórias, como xilanases e enzimas com Atividade Auxiliar (família AA do CAZy; Carbohydrate Active Enzymes; http://www.cazy.org) como potencializadores para a atuação conjunta em preparos comerciais de celulases (SUN et al., 2015). Em especial, as enzimas oxidativas foram a descoberta chave, pois estão presentes nos complexos enzimáticos secretados principalmente por fungos filamentosos degradadores de biomassa, como basidiomicetos e ascomicetos (PHILLIPS et al., 2011). Portanto, estudos envolvendo a suplementação de enzimas auxiliares em preparos de celulases tem sido de grande interesse. 
Sendo assim, foi dado enfoque a uma enzima oxidativa com atividade indireta na degradação da biomassa, a qual apresenta um grande potencial para estudos de suplementação em coquetéis enzimáticos, a celobiose desidrogenase.

\subsection{Família de enzimas com Atividade Auxiliar (AA3)}

A celobiose desidrogenase (CDH, EC 1.1.99.18) é uma enzima oxidativa classificada na família AA3 do CAZy. Devido à recente inserção das enzimas auxiliares neste banco de dados, esta família tem sido pouco estudada, com apenas 37 proteínas caracterizadas bioquimicamente, dentre estas 14 CDHs (SÜTZL et al., 2018). As enzimas classificadas na família AA3 não atuam diretamente nos componentes da biomassa (celulose, hemicelulose, pectina ou lignina) e, sim, geram produtos (principalmente, peróxido de hidrogênio $-\mathrm{H}_{2} \mathrm{O}_{2}$ ) que são utilizados por outras enzimas de Atividade Auxiliar ou auxiliando glicosil hidrolases (GH) pelo aumento da acessibilidade, na despolimerização da biomassa (SÜTZL et al., 2018). A CDH faz parte do complexo enzimático de vários basidiomicetos e ascomicetos, sendo secretada juntamente com enzimas celulolíticas, hemicelulolíticas e ligninolíticas, evidenciando sua importância no complexo e dinâmico processo da degradação da parede celular de plantas (LUDWIG et al., 2010).

\subsubsection{Celobiose desidrogenase (CDH)}

A CDH é a única hemoflavoproteína extracelular conhecida até o momento (ZÁMOCKY et al., 2006). É uma glicoproteína monomérica pertencente à família das glucose-methanol-choline (GMC) das oxidorredutases. Atua preferencialmente em oligossacarídeos contendo ligações $\beta 1 \rightarrow 4$ e, principalmente, com $\beta$-D-glicose na extremidade redutora (HENRIKSSON; PETTERSSEN; JOHANSSON, 2000). Por consequência, oxida eficientemente celobiose, celodextrinas e lactose, e atua com baixa eficiência catalítica em glicose, manose, galactose e oligossacarídeos derivados do amido (SÜTZL et al., 2018; ZÁMOCKY et al., 2006).

A reação da $\mathrm{CDH}$ ocorre pela oxidação do substrato na posição $\mathrm{C} 1$ do açúcar, gerando um intermediário hemiacetal que é convertido à lactona e, espontaneamente, é hidrolisado à ácido carboxílico (por exemplo, ácido celobiônico) (Figura 2). Dois elétrons são obtidos da oxidação do substrato e a enzima é capaz de transferi-los para aceptores de um elétron (ferricianeto, radicais fenóxi e principalmente citocromo $c$ ) ou de dois elétrons 
(quinonas, íon triiodeto, oxigênio molecular e diclorofenolindofenol - DCIP) (HENRIKSSON; PETTERSSEN; JOHANSSON, 2000).

Figura 2 - Oxidação do substrato pela ação da CDH.

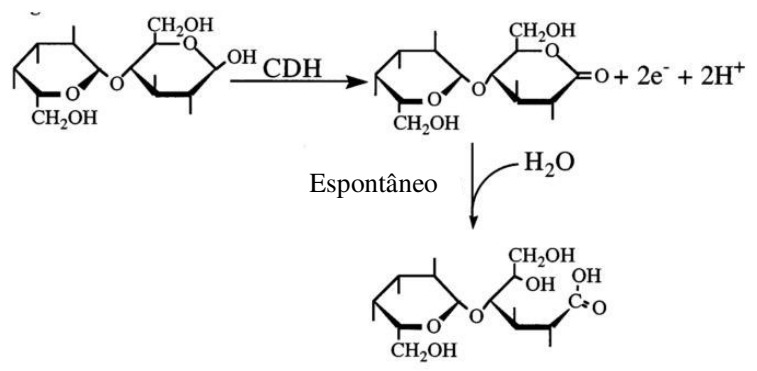

Fonte: (HENRIKSSON; PETTERSSEN; JOHANSSON, 2000).

Nota: A oxidação do substrato forma uma lactona que será espontaneamente hidrolisada a ácido carboxílico, gerando dois elétrons que são retidos na $\mathrm{CDH}$.

A CDH apresenta atividade efetiva apenas quando os cofatores dinucleotídeo flavinaadenina (FAD) e o haem $b$ (ou heme b) estão presentes em sua estrutura e posicionados nos domínios Citocromo (CYT) e Desidrogenase (DH), localizados nas porções $N$ - e $C$-terminal, respectivamente (Figura 3 e Figura 34). Os domínios são conectados por um linker flexível que promove a mobilidade necessária entre eles, podendo-se observar a conformação aberta ou fechada da estrutura da CDH (TAN et al., 2015), como indicado na Figura 3. A conformação fechada promove a transferência interna de elétrons entre os domínios DH e CYT, enquanto que a configuração aberta favorece a transferência externa dos elétrons via domínio CYT para um aceptor de elétrons presente no meio. O aceptor de elétrons que atualmente tem sido alvo de estudos, é a enzima mono-oxigenase lítica de polissacarídeo (LPMO, sigla em inglês) (TAN et al., 2015) e sua relação com a CDH será explorada no tópico seguinte (veja seção 2.3.2 LPMO e CDH). É importante ressaltar que o substrato é capaz de ter acesso ao sítio catalítico das enzimas $\mathrm{CDH}$, mesmo na conformação fechada. Além disso, a característica movimentação dos domínio na estrutura da CDH é um dos grandes desafios na expressão heteróloga e produção dessa enzima (MA et al., 2017).

Em termos de mecanismo catalítico, a CDH promove a oxidação do substrato gerando a liberação de dois elétrons que são capturados pela própria enzima (Figura 4). O cofator FAD recebe esses elétrons e muda do estado oxidado $\left(\mathrm{Fl}_{\mathrm{ox}}\right)$ para o estado reduzido $\left(\mathrm{FlH}_{2}\right)$. O $\mathrm{FlH}_{2}$ pode transferir os elétrons diretamente para um aceptor de dois elétrons (como o DCIP) ou transferir um elétron para o cofator heme b, presente no domínio CYT (Figura 4). 
Figura 3 - Estrutura tridimensional da $\mathrm{CDH}$ em suas diferentes conformações.

a

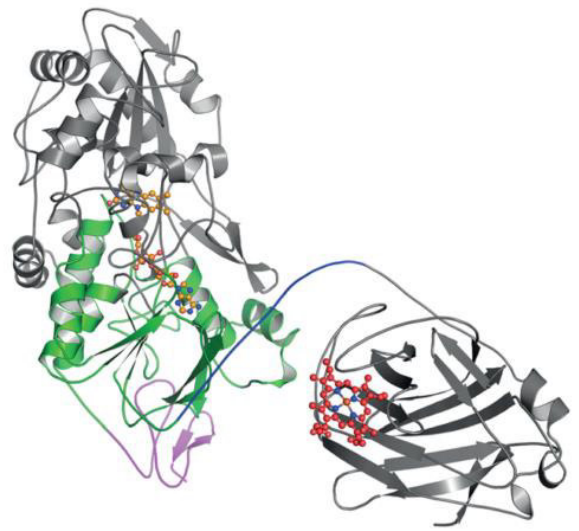

b

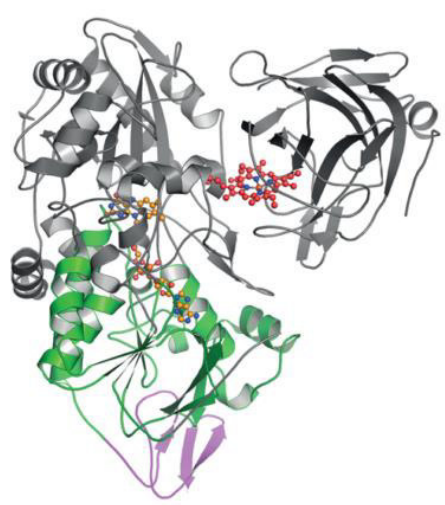

Fonte: (SÜTZL et al., 2018).

Nota: a. Estrutura da CDH em sua conformação aberta (Neurospora crassa PDB 4QI7 ).

b. Estrutura fechada da CDH (Myricoccum thermophilum 4QI6) (TAN et al., 2015).

O domínio de ligação do FAD está indicado pela cor verde, o cofator FAD pela estrutura em laranja, e o domínio citocromo em cinza escuro contendo o haem $b$ em vermelho. O CBM está representado pela estrutura com cor magenta.

O heme b reduzido é capaz de se reoxidar ao doar o elétron para aceptores de um elétron (como o citocromo c) (HENRIKSSON; JOHANSSON; PETTERSSON, 1993; HENRIKSSON; PETTERSSEN; JOHANSSON, 2000), assim, fechando o ciclo de reações de oxidação e redução da CDH.

Figura 4 - Esquema da ação catalítica da $\mathrm{CDH}$ na oxidação do substrato e da interação da $\mathrm{CDH}$ com os diferentes tipos de aceptores de elétrons e os estados de oxidação de cada cofator flavina e heme b.

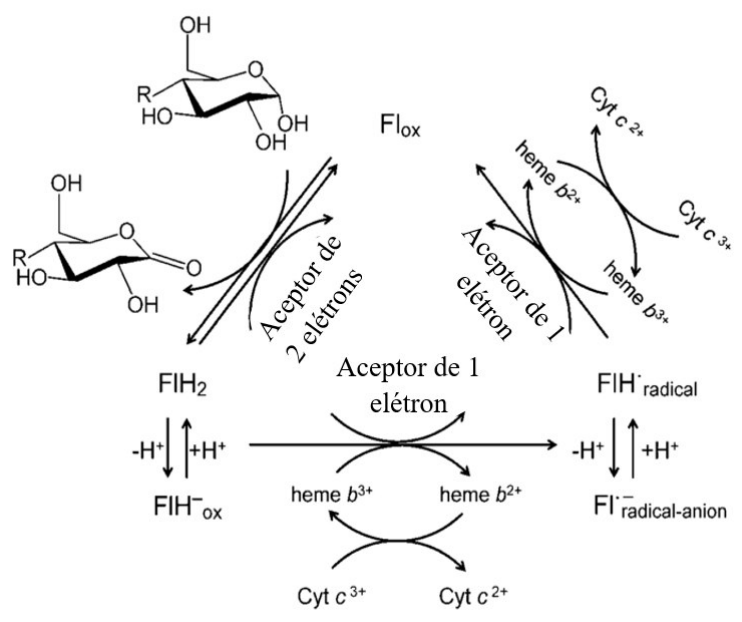

Fonte: Adaptado de (LUDWIG et al., 2010).

Nota: Fl: flavina 
Um detalhe já relatado, é que o cofator FAD é capaz de reduzir ambos tipos de aceptores de elétrons (aceptor de 1 ou 2 elétrons). Porém, a redução de aceptores de 1 elétron acontece em taxas muito menores em relação ao domínio CYT (HENRIKSSON; PETTERSSEN; JOHANSSON, 2000).

A função biológica da CDH ainda não está bem esclarecida, no entanto sabe-se que:

a) Oxida a celobiose, prevenindo a inibição de algumas enzimas (principalmente celobiohidrolases) pelo produto (LUDWIG et al., 2010);

b) Promove a redução de íons $\mathrm{Fe}^{3+}$ e $\mathrm{O}_{2}$, gerando a produção de $\mathrm{H}_{2} \mathrm{O}_{2}$ necessários para a reação de Fenton (KREMER; WOOD, 1992);

c) Inibe a polimerização de radicais aromáticos e fenólicos produzidos pela lignina peroxidase e por lacases;

d) Reduz precipitados de $\mathrm{MnO}_{2}$ liberando íons $\mathrm{Mn}^{2+}$ para manganês peroxidase (HILDÉN et al., 2000), a qual também está envolvida na degradação da lignina;

e) Transfere elétrons para a LPMO, desencadeando a ação da LPMO na degradação e rompimento da estrutura cristalina da celulose (PHILLIPS et al., 2011).

Todas as prováveis funções da CDH estão esquematizadas na Figura 5, exceto pela doação de elétrons para a LPMO.

O domínio CYT é capaz de transferir um elétron à sais de ferro (como o oxalato de ferro) e gerar espécies iônicas de $\mathrm{Fe}^{2+}$, que poderão reagir com $\mathrm{H}_{2} \mathrm{O}_{2}$ (produzido a partir da redução de molécula de oxigênio) e gerar o radical hidroxila altamente reativo $(\cdot \mathrm{OH})$ via reação de Fenton. O radical hidroxila é capaz de oxidar qualquer molécula orgânica disponível e, portanto, potencializar a degradação dos principais componentes da biomassa (celulose, hemicelulose e lignina) (MASON et al., 2003).

$\mathrm{Na}$ lignina, o radical $\cdot \mathrm{OH}$ é capaz de reagir com estruturas não-fenólicas por vários mecanismos, favorecendo a desmetilação ou se inserindo nos anéis aromáticos. Ao final, ocorre a introdução de sítios fenólicos na lignina, o que facilita a oxidação dessa macromolécula (HAMMEL et al., 2002). O mecanismo sugerido para a oxidação do Carbono $\alpha$ da lignina está representado na Figura 6. O radical · OH se insere em uma porção não fenólica da lignina, formando uma estrutura de ressonância no anel aromático. A estabilidade do anel aromático retorna com a quebra de uma ligação éter, ocorrendo a despolimerização da lignina. O elétron não pareado do radical fenóxi é alocado ao Carbono $\alpha$, reagindo com uma molécula de $\mathrm{O}_{2}$. Uma molécula de superóxido $\left(\cdot \mathrm{O}_{2} \mathrm{H}\right)$ é liberada, formando um carbonil no Carbono $\alpha$ (oxidação do Carbono $\alpha$ ). 
Figura 5 - Esquema das possíveis funções da CDH durante a despolimerização da lignocelulose.

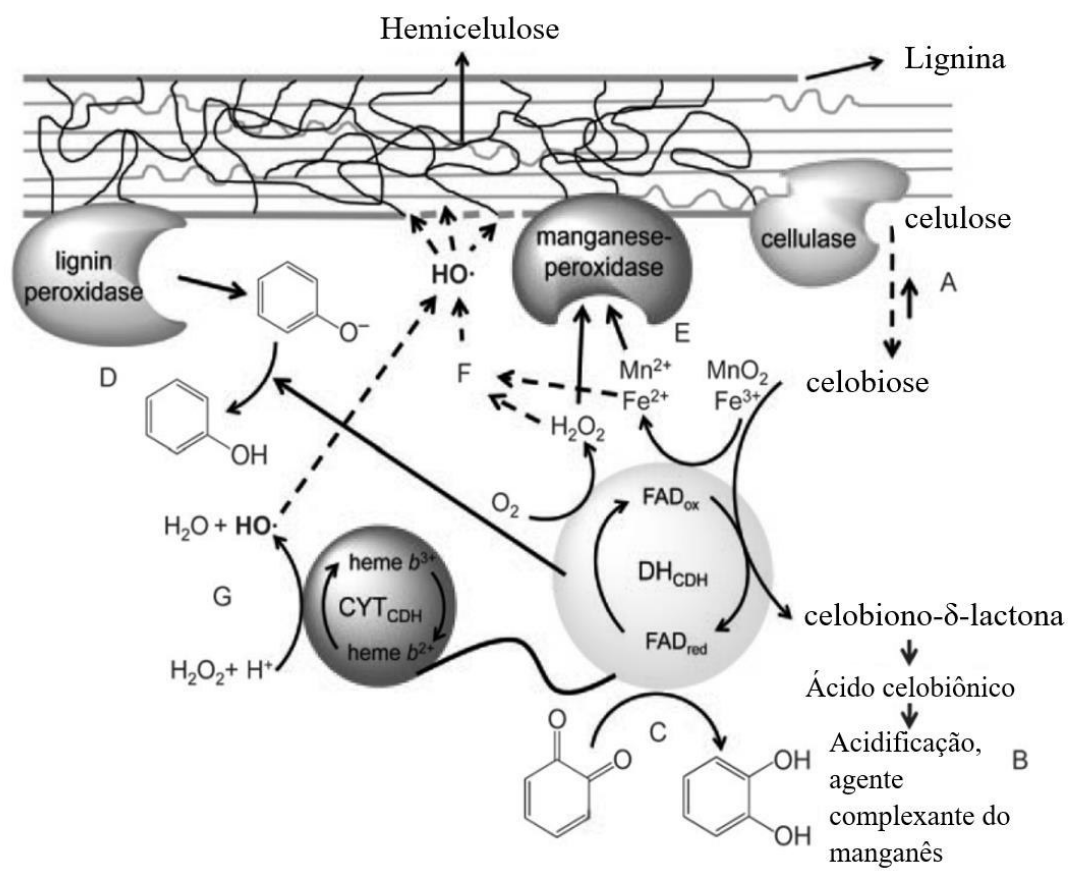

Fonte: Adaptado de (LUDWIG et al., 2010).

Nota: A: Diminuir a inibição das celulases pela celobiose.

B: Acidificação e solubilização de íons metálicos.

C: Redução de quinonas tóxicas pela formação de difenóis.

D e E: Redução de radicais fenóxi, produtos de reação de lignina peroxidases ou lacases (prevenindo repolimerização) e manganês peroxidase.

F e G: produção de radicais hidroxil pela reação de Fenton e pela redução de $\mathrm{H}_{2} \mathrm{O}_{2}$ pelo domínio CYT.

Ao final, forma-se uma extremidade fenólica da lignina que poderá ser oxidada por enzimas como manganês peroxidase e lacases (HENRIKSSON; PETTERSSEN; JOHANSSON, 2000). Já quando o radical • OH se insere na posição do anel aromático que possui a substituição de um grupo metil, ocorre a liberação de metanol e formação de um radical fenóxi de lignina (desmetoxilação). Se o $\bullet \mathrm{OH}$ atacar preferencialmente a ligação éter $\beta-\mathrm{O}-4$, ocorrerá a quebra da molécula (clivagem da ligação éter $\beta$-O-4). Em um outro caso, se o $\bullet \mathrm{OH}$ se inserir em uma posição não substituída do anel aromático, o intermediário formado sofre oxidação (perde um próton) e permanece com o grupo hidroxil no anel aromático (hidroxilação) (HAMMEL et al., 2002).

Devido a sua propriedade de transferência de elétrons, a $\mathrm{CDH}$ é uma enzima que apresenta um grande potencial de aplicação em diversos setores (LUDWIG et al., 2010). A CDH pode ser utilizada como componente de anodos de células combustíveis, biosensores (medição do conteúdo de celobiose e lactose), biorremediação (reduzindo corantes/quinonas tóxicas de efluentes) e processos de branqueamento de polpa (pela capacidade de geração de radicais hidroxila) (HENRIKSSON; PETTERSSEN; JOHANSSON, 2000). Em especial, 
CDHs com maior estabilidade térmica apresentam grande vantagem na aplicação em células biocombustíveis e biosensores, devido a sua maior estabilidade e possibilidade de operar a temperaturas mais elevadas (ZÁMOCKY et al., 2008). Neste trabalho, a aplicação da CDH foi focada no uso da enzima para potencializar a degradação da biomassa auxiliando outras enzimas do complexo enzimático.

Figura 6 - Esquematização das reações típicas na lignina realizadas pelo radical hidroxila.

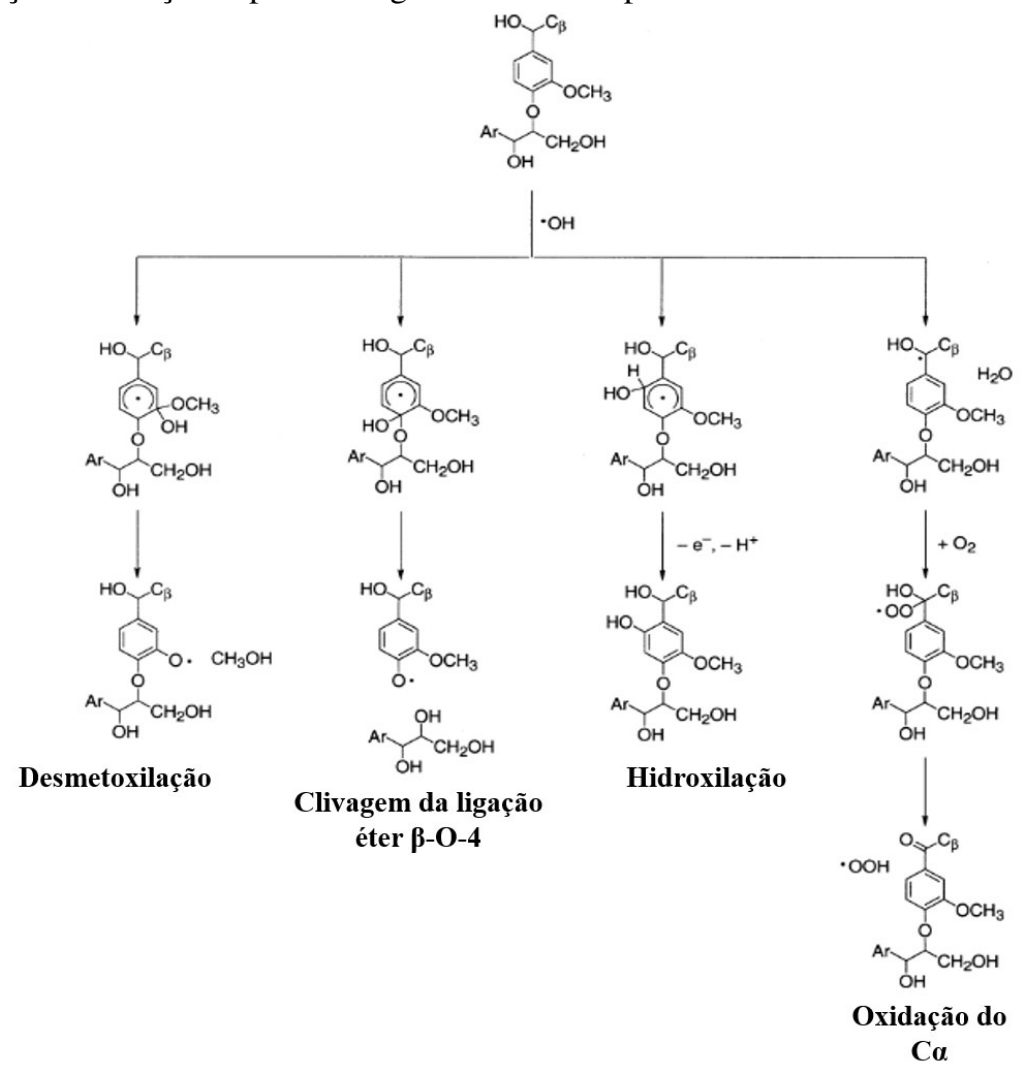

Fonte: (HAMMEL et al., 2002).

\subsubsection{LPMO e CDH}

As LPMOs (lytic polissacharide monooxigenase) são enzimas oxidativas pertencentes as famílias que auxiliam a atividade de outras enzimas (AA) e que atuam em: celulose (AA9, AA10 e AA15) (FORSBERG et al., 2011; LEVASSEUR et al., 2013; SABBADIN et al., 2018), em quitina (AA11) (HEMSWORTH et al., 2014), em amido (AA13) (VU et al., 2014) e em hemicelulose (AA14) (COUTURIER et al., 2018) (CANTAREL et al., 2009; LOMBARD et al., 2013). As famílias das LPMOs que atuam na degradação da biomassa por meio da oxidação da celulose cristalina liberam como produto oligômeros oxidados no carbono $\mathrm{C} 1$ e/ou C4 (Figura 7A). A atividade enzimática das LPMOs depende da presença de moléculas pequenas redutoras como ácido ascórbico, 
glutationa reduzida e ácido gálico para reduzir o elemento cobre da sua estrutura (FORSBERG et al., 2011; QUINLAN et al., 2011; WESTERENG et al., 2011). Além desses elementos, as LPMOs podem receber elétrons da própria biomassa lignocelulósica, em que a lignina é a principal responsável (BRENELLI et al., 2018; RODRÍGUEZ-ZÚÑIGA et al., 2015). A lignina é uma excelente fonte de elétrons, pois estes estão deslocalizados na sua estrutura tornando essa macromolécula altamente estável mesmo na sua forma oxidada (WESTERENG et al., 2015). Com a descoberta e elucidação do mecanismo de ação das LPMOs, foi atribuído a CDH uma nova função, e talvez a mais importante, de atuar conjuntamente com a LPMO através da doação de elétrons pela $\mathrm{CDH}$, para a ativação da LPMO (BODENHEIMER et al., 2017).

O mecanismo da cooperação entre CDH e LPMO para clivagem da celulose recalcitrante está representada na Figura 7B. A redução do $\mathrm{Cu}^{2+}$ para $\mathrm{Cu}^{+}$presente na LPMO é feita pela $\mathrm{CDH}$ (CDH contendo um elétron no domínio CYT), em seguida ocorre a formação de um intermediário cobre-superóxido na LPMO (pela transferência interna de elétrons na LPMO). Esse intermediário é capaz de retirar um átomo de hidrogênio no carbono 1 (C1 - LPMO tipo 1) ou carbono 4 (C4 - LPMO tipo 2) do sacarídeo, resultando na formação de um radical do sacarídeo e um intermediário cobre-hidroperóxido. Nessa etapa, a CDH atua novamente com doação de um elétron para a LPMO que facilita a clivagem da ligação O-O do intermediário cobre-hidroperóxido, liberando água e um radical de óxido de cobre na LPMO. Esse último intermediário tem afinidade pelo substrato-radical e realiza a hidroxilação do polissacarídeo na posição C1 ou C4 (dependendo de onde ocorreu a retirada de hidrogênio na etapa anterior). A inserção do átomo de oxigênio na estrutura da celulose leva a desestabilização da ligação glicosídica que elimina o resíduo de glicose adjacente, com formação de uma lactona ou cetoaldose (PHILLIPS et al., 2011).

No estudo de Phillips et al. (2011), a incubação de uma LPMO com CDH (ambos de Neurospora crassa) em PASC (phosphoric acid swollen celulose, em inglês) resultou na liberação de ácidos aldônicos com cerca de 2 a 9 resíduos de glicose, enquanto que a incubação somente com LPMO ocorreu apenas uma pequena degradação desse material (talvez pela contaminação com celulases) (PHILLIPS et al., 2011). Tal fato evidencia a cooperação entre essas enzimas, que já foi comprovado por outros estudos (BEY et al., 2013; SYGMUND et al., 2012). Trabalhos também comentam o aumento da conversão da celulose pela suplementação de celulases com LPMOs e juntamente com CDH na sacarificação da celulose (LANGSTON et al., 2011; SWEENEY; VLASENKO; ABBATE, 2010). Por fim, 
o estudo de Bey et al. (2013), sugere que o sinergismo entre LPMO e CDH tem indícios de depender da concentração dessas enzimas e do tipo de substrato.

A suplementação de LPMOs, e também de diferentes tipos de LPMOs (tipo 1 ou 2) nos coquetéis enzimáticos, juntamente com $\mathrm{CDH}$, vem sendo uma estratégia promissora para reduzir consideravelmente a carga enzimática necessária para a degradação da lignocelulose em seus monômeros (PHILLIPS et al., 2011).

Figura 7 - Mecanismo da reação da LPMO (PMO) em celulose e função da CDH em cooperação com LPMO.
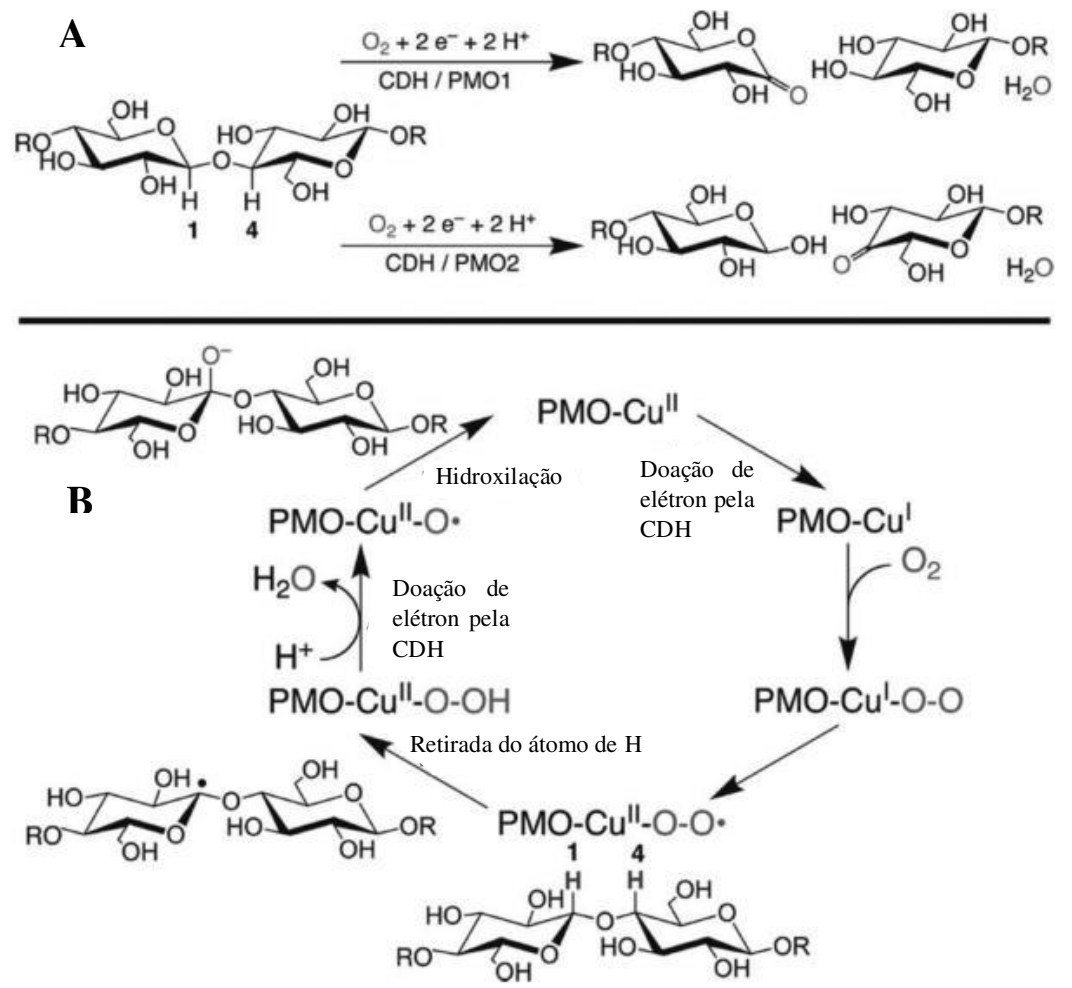

Fonte: Adaptado de (PHILLIPS et al., 2011).

Nota: A: Tipos de produtos obtidos pela ação de LMPO tipo 1 (formação de lactona pela hidroxilação no carbono 1) e tipo 2 (formação de cetoaldose pela retirada de hidrogênio no carbono 4).

B: O domínio heme da $\mathrm{CDH}$ ao transferir um elétron para a LPMO permite a redução do $\mathrm{Cu}^{2+}$ para $\mathrm{Cu}^{+}$ da LPMO e ligação da $\mathrm{O}_{2}$ na estrutura da LPMO.

O intermediário LPMO-superóxido formado é capaz de retirar o hidrogênio na posição 1 ou 4 do polissacarídeo e a segunda transferência de elétron da $\mathrm{CDH}$ para esse intermediário realiza uma clivagem homolítica $(\mathrm{Cu}-\mathrm{O} \bullet)$ do $\mathrm{Cu}$-hidroperóxido.

$\mathrm{O}$ intermediário de óxido de cobre (PMO-Cu-O•) se liga ao radical do substrato ocasionando a hidroxilação, em que o átomo de oxigênio desestabiliza a ligação glicosídica liberando o resíduo de glicose adjacente.

\subsection{Enzimas oxidativas degradadoras de lignina}

Enquanto as enzimas de degradação de carboidratos são enzimas extracelulares altamente específicas para a quebra de ligações glicosídicas, as enzimas oxidativas de 
degradação da lignina são responsáveis por gerar espécies altamente reativas (radicais livres) que causam a clivagem de ligações carbono-carbono e ligações éter (LEVASSEUR et al., 2008). Nessa seção será apresentada a relação da CDH com o mecanismo de reação das enzimas oxidativas degradadoras de lignina.

\subsubsection{Lignina Peroxidase (LiP) e CDH}

A lignina peroxidase (LiP) é amplamente estudada por sua capacidade de despolimerizar a lignina in vivo na presença de $\mathrm{H}_{2} \mathrm{O}_{2}$ e é conhecida por ter ação não específica no substrato (KAMESHWAR; QIN, 2016; VALLI; WARIISHI; GOLD, 1990). É capaz de oxidar compostos fenólicos, não-fenólicos e compostos orgânicos utilizando o $\mathrm{H}_{2} \mathrm{O}_{2}$ (VALLI; WARIISHI; GOLD, 1990).

O mecanismo catalítico da LiP é apresentado na Figura 8, com a enzima CDH atuando no produto final de radicais fenólicos. A LiP contém um Fe(III) como cofator na sua estrutura reduzida que, na presença de $\mathrm{H}_{2} \mathrm{O}_{2}$, é oxidado a $\mathrm{Fe}(\mathrm{IV})$ formando o Composto I. O Composto II é formando pela oxidação de um substrato (no caso, representado pelo álcool veratrílico, VA) pelo Composto I, em que se libera um radical catiônico do substrato $\left(\mathrm{VA}^{\bullet+}\right)$ (via 1). O retorno para a LiP reduzida pode ser feito por outra molécula de VA (via 2) ou pelo mesmo radical VA*+ (via 3). Na redução dos Compostos I e II (vias 1 e 2) ocorre a formação de radicais catiônicos $\left(\mathrm{VA}^{\cdot+}\right)$.

Figura 8 - Ciclo catalítico da lignina peroxidase utilizando peróxido de hidrogênio como insumo para oxidar e formar radical de seu substrato, no caso representado pelo álcool veratrílico.

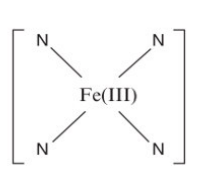

LiP
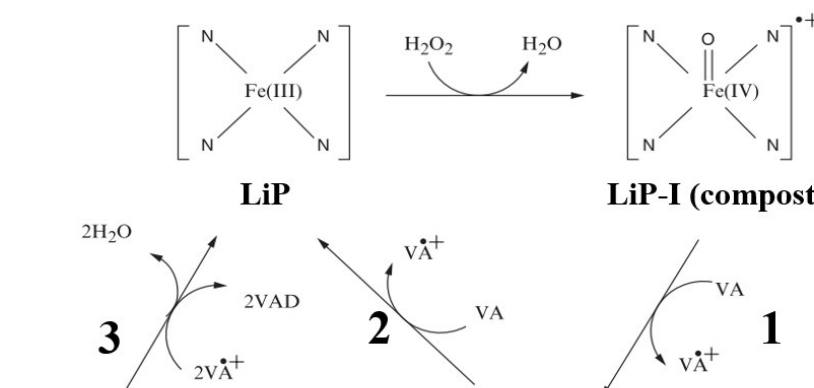

LiP-I (composto I)

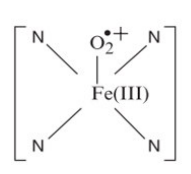

LiP-III (composto III)

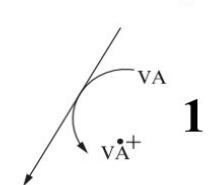

1

Fonte: Adaptado de (WONG, 2009).

Nota: LiP: Lignina peroxidase.

$\mathrm{H}_{2} \mathrm{O}_{2}$ : Peróxido de hidrogênio.

VA: Álcool veratrílico e VAD: Veratraldeído. 
No entanto, esses radicais na presença de $\mathrm{O}_{2}$ podem se agrupar e repolimerizar. Neste estágio, a ação da CDH é importante para reduzir esses compostos, prevenindo sua repolimerização (ANDER; SENA-MARTINS; DUARTE, 1993; KAMESHWAR; QIN, 2016; TIEN; KIRK, 1984; WONG, 2009). Além disso, um estudo também relatou a habilidade da $\mathrm{CDH}$ em reduzir o Composto II e restaurar o ciclo da LiP, e pela habilidade da $\mathrm{CDH}$ de produzir $\mathrm{H}_{2} \mathrm{O}_{2}$ de auxiliar na formação do Composto I (ANDER; SENAMARTINS; DUARTE, 1993).

\subsubsection{Manganês Peroxidase (MnP) e CDH}

A Manganês Peroxidase (MnP) é uma enzima única por utilizar íon manganês como substrato na reação. O ciclo catalítico ocorre de acordo com as reações apresentadas a seguir, e as funções da $\mathrm{CDH}$ nesse ciclo estão representadas na Figura 9. A catálise da MnP se inicia na presença de $\mathrm{H}_{2} \mathrm{O}_{2}$ (Reação1), formando o Composto I (MnP-I) que ao reagir com $\mathrm{Mn}^{2+}$ irá oxidar o $\mathrm{Mn}^{2+}$ à $\mathrm{Mn}^{3+}$ (Reação 2) e gerar o Composto II (MnP-II). O Composto II também é capaz de reagir com $\mathrm{Mn}^{2+}$ e gerar íons $\mathrm{Mn}^{3+}$ (Reação 3) (WONG, 2009).

$$
\begin{aligned}
& \mathrm{MnP}+\mathrm{H}_{2} \mathrm{O}_{2} \rightarrow \mathrm{MnP}-\mathrm{I}+\mathrm{H}_{2} \mathrm{O} \\
& \mathrm{MnP}-\mathrm{I}+\mathrm{Mn}^{2+} \rightarrow \mathrm{MnP}-\mathrm{II}+\mathrm{Mn}^{3+} \\
& \mathrm{MnP}-\mathrm{II}+\mathrm{Mn}^{2+} \rightarrow \mathrm{MnP}+\mathrm{Mn}^{3+}+\mathrm{H}_{2} \mathrm{O}
\end{aligned}
$$

Após o $\mathrm{Mn}^{3+}$ ser liberado pela enzima, é necessário que esse íon seja complexado com oxalato, malonato ou também com o ácido celobiônico (produzido pela CDH ao oxidar a celobiose) para se manter estável. Na forma complexada, o $\mathrm{Mn}^{3+}$ é o mediador responsável por oxidar moléculas orgânicas e produzir intermediários fenólicos (via 3) (Figura 9). Os intermediários fenólicos sofrem rearranjos e liberam vários produtos não-fenólicos, devido à sucessivas clivagens na sua estrutura (ROY et al., 1994). Desse modo, é feita a despolimerização da lignina pela $\mathrm{MnP}$.

Portanto, a CDH auxilia a $\mathrm{MnP}$ dissolvendo precipitados de $\mathrm{MnO}_{2}$ (via 1) (Figura 9), ao produzir ácido celobiônico que se complexam com íons $\mathrm{Mn}^{3+}$ reativos (via 2) e ao reduzir quinonas (via 3) (ROY et al., 1994; WONG, 2009). 
Figura 9 - Funções da CDH in vivo auxiliando a ação da MnP.

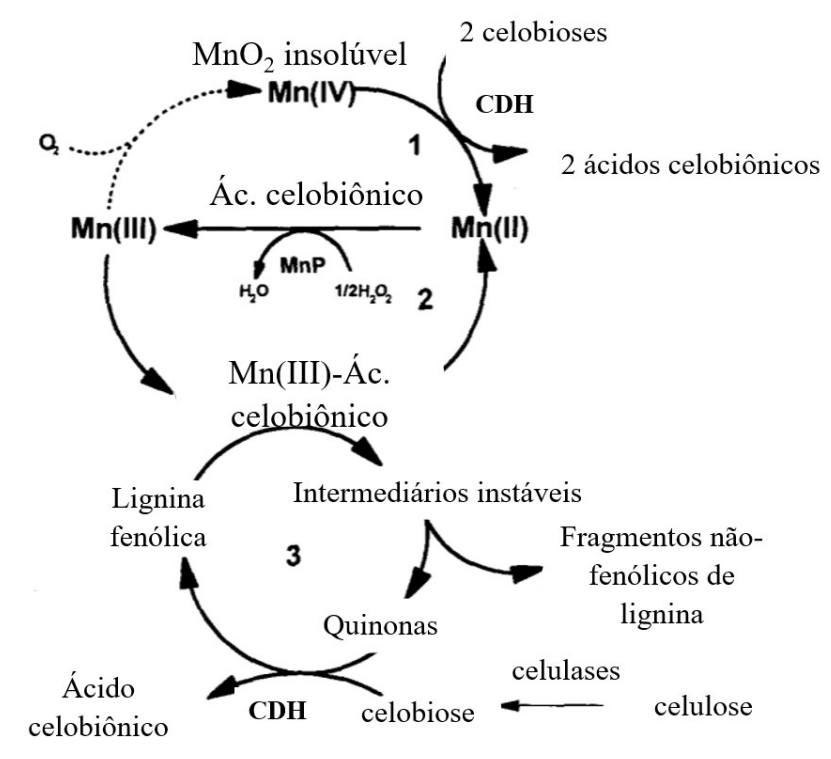

Fonte: Adaptado de (ROY et al., 1994).

Nota: Ciclo 1 e 2: A CDH reduz o composto insolúvel $\mathrm{MnO}_{2}$ (ciclo 1) mantendo-o disponível na forma de $\mathrm{Mn}^{2+}$ para ação catalítica da $\mathrm{MnP}$ (ciclo 2).

Ciclo 3: A CDH também reduz quinonas presentes na lignina possibilitando a oxidação posterior por $\mathrm{Mn}^{3+}$ complexado.

\subsection{Fungos termofílicos e enzimas termoestáveis}

$\mathrm{Na}$ natureza, os fungos exibem grande diversidade de morfologias e de características. A capacidade de se desenvolverem em temperaturas elevadas é uma das características que vem sendo exploradas, pois, devido a este fator, suas biomoléculas (principalmente enzimas) podem apresentar propriedades como termoestabilidade, sendo mais resistentes à desnaturação e à proteólise. Esses tipos de fungos são denominados fungos termofílicos (ou termófilos) e habitam, principalmente, ambientes geotermicamente estáveis e possuem crescimento em temperaturas acima de $50{ }^{\circ} \mathrm{C}$ (GOMES et al., 2007; KUMAR; NUSSINOV, 2001; MADIGAN; OREN, 1999). Entre os fungos termofílicos com potencial biotecnológico, encontram-se os fungos filamentosos A. niveus e $M$. thermophila. O A. niveus é capaz de secretar várias enzimas hidrolíticas e $M$. thermophila capaz de secretar uma série de enzimas oxidativas (dados não publicados). Portanto, apresentam características distintas e potencial para ter seus genes explorados e aplicados em indústrias, como forma de inserir enzimas mais eficientes e resistentes termicamente nos processos.

Aplicando-se temperaturas elevadas em processos industriais é possível diminuir o risco de contaminação por microrganismos mesofílicos, favorecer a solubilidade dos substratos e produtos no meio reacional, aumentar o coeficiente de difusão dos substratos e 
inibir enzimas degradativas. Ao inserir enzimas termoestáveis nos processos a altas temperaturas permite-se maior reciclagem das enzimas (KRAHE; ANTRANIKIAN; MÄIRKL, 1996; KUMAR; SWATI, 2004; MOZHAEV, 1993) e diminuir a carga enzimática requerida, pois, de acordo com Zamost et al (1991), um aumento de $10{ }^{\circ} \mathrm{C}$ no processo pode duplicar a taxa de reação enzimática (ZAMOST; NIELSEN; STARNES, 1991). Ou seja, enzimas termoestáveis tem potencial de aumentar a taxa de reciclabilidade dos biocatalisadores e realizarem a mesma ação catalítica no substrato com uma carga menor de enzimas. Assim, diminuindo o custo do processo e promovendo uma maior competitividade ao produto final (GUDYNAITE-SAVITCH; WHITE, 2016).

Com um enfoque em produção de etanol $2 \mathrm{G}$, muitas etapas de desconstrução da biomassa envolvem altas temperaturas. Na etapa de hidrólise enzimática, a reação dispende vários dias, submetendo as enzimas à $50{ }^{\circ} \mathrm{C}$. A elevada temperatura é prejudicial a estabilidade das enzimas, afetando a atividade enzimática e eficiência do processo. Uma alternativa é prospectar e estudar enzimas termoestáveis com ação na degradação da biomassa (GOMES et al., 2016). O desenvolvimento de tecnologia para auxiliar na solução desse inconveniente é proposta nesse projeto pelo estudo bioquímico e análise do potencial da enzima oxidativa $\mathrm{CDH}$, provinda do fungo termofílico $M$. thermophila $\mathrm{M} 77$, na hidrólise do bagaço de cana juntamente com coquetéis de (hemi)celulases.

\subsection{CDH e tecnologia do DNA recombinante}

Os basidiomicetos são os melhores degradadores de lignocelulose e são os microrganismos que produzem as CDHs em grande quantidade, portanto, por muito tempo, as CDHs desses organismos foram as principais alvo dos estudos (HARREITHER et al., 2011; SULEJ et al., 2013a, 2013b; ZÁMOCKY et al., 2006). Porém, com o aumento do número de genomas fúngicos depositados em bancos de dados, permitiu-se a identificação de CDHs nos ascomicetos. Pelo fato do filo dos ascomicetos conter representantes que suportam condições extremas de ambiente, como elevadas temperaturas e variações de pHs, as CDHs destes organismos, produzidas heterólogamente passaram a ser exploradas. Até o momento, cerca de 10 genes de $\mathrm{CDH}$ de origem de fungos filamentosos foram expressos heterologamente em diferentes sistemas de expressão (Tabela 1). As CDHs de ascomicetos estão bastante presentes, representando 6 genes clonados e produzidos heterologamente. Sendo assim, este trabalho insere mais uma $\mathrm{CDH}$ (M77CDH) do ascomiceto Thermothelomyces thermophila (previamente denominado Myceliophthora thermophila M77) (M77CDH) clonada e expressa em Aspergillus nidulans linhagem A773, de acordo 
com metodologia de SEGATO et al. (2012), como forma de estudar enzimas de ascomicetos termofílicos (SEGATO et al., 2012).

Tabela 1 - CDHs de vários fungos clonadas até o momento, indicando o organismo de expressão, quando utilizado.

\begin{tabular}{|c|c|c|c|c|c|}
\hline Número de acesso & Identificação CDH & Organismo origem & $\begin{array}{c}\text { Filo do organismo } \\
\text { origem }\end{array}$ & $\begin{array}{c}\text { Organismo } \\
\text { expressão }\end{array}$ & Referência \\
\hline ADX41688.1 & P. cinnabarinus CDH & $\begin{array}{l}\text { Pycnoporus } \\
\text { cinnabarinus }\end{array}$ & Basidiomiceto & $\begin{array}{l}\text { Pichia } \\
\text { pastoris }\end{array}$ & (BEY et al., 2011) \\
\hline $\begin{array}{l}\text { XP_956591.1 e } \\
\text { XP_958234.1 }\end{array}$ & CDHIIA е CDHIIB & Neurospora crassa & Ascomiceto & $\begin{array}{l}\text { Pichia } \\
\text { pastoris }\end{array}$ & (SYGMUND et al., 2012) \\
\hline AGS09130.1 & CDH1 & $\begin{array}{l}\text { Pycnoporus } \\
\text { sanguineus }\end{array}$ & Basidiomiceto & $a^{*}$ & (SULEJ et al., 2013a) \\
\hline AGE45679.1 & P. lindtneri $\mathrm{CDH}$ & Phlebia lindtneri & Basidiomiceto & $a^{*}$ & (SULEJ et al., 2013b) \\
\hline AGS09131.1 & $\mathrm{CuCDH}$ & Cerrena unicolor & Basidiomiceto & $a^{*}$ & (SULEJ et al., 2015) \\
\hline XP_001835032.2 & $\mathrm{CDH} c c$ & Coprinopsis cinerea & Basidiomiceto & $\begin{array}{l}\text { Aspergillus } \\
\text { niger }\end{array}$ & (TURBE-DOAN et al., 2013) \\
\hline XP_001907754.1 & CDHрa & Podospora anserina & Ascomiceto & $\begin{array}{l}\text { Aspergillus } \\
\text { niger }\end{array}$ & (TURBE-DOAN et al., 2013) \\
\hline XP_003655350 & $\begin{array}{l}\text { P. chrysosporium } \\
\text { CDH }\end{array}$ & $\begin{array}{l}\text { Phanerochaete } \\
\text { chrysosporium }\end{array}$ & Basidiomiceto & $\begin{array}{l}\text { Pichia } \\
\text { pastoris }\end{array}$ & (YOSHIDA et al., 2001) \\
\hline AEO69014.1 & TtCDH & Thielavia terrestris & Ascomiceto & $\begin{array}{l}\text { Aspergillus } \\
\text { oryzae }\end{array}$ & (LANGSTON et al., 2012) \\
\hline ABS45567.2 & $M t \mathrm{CDH}$ & $\begin{array}{l}\text { Myriococcum } \\
\text { thermophilum }\end{array}$ & Ascomiceto & $\begin{array}{l}\text { Pichia } \\
\text { pastoris }\end{array}$ & (ZÁMOCKÝ et al., 2008) \\
\hline XP_003663382.1 & $\mathrm{CDH}_{\text {st }}$ & $\begin{array}{l}\text { Myceliophthora } \\
\text { thermophila }\end{array}$ & Ascomiceto & $a^{*}$ & $\begin{array}{l}\text { (SUBRAMANIAM; } \\
\text { NAGALLA; } \\
\text { RENGANATHAN, 1999) }\end{array}$ \\
\hline ADT70772.1 & CtCDH & $\begin{array}{l}\text { Crassicarpon } \\
\text { thermophilum }\end{array}$ & Ascomiceto & $\begin{array}{c}\text { P. pastoris / } \\
\text { A. niger / } \\
\text { T. reesei }\end{array}$ & (MA et al., 2017) \\
\hline ATJ01065.1 & $V v C D H$ & Volvariella volvacea & Basidiomiceto & $\begin{array}{l}\text { Pichia } \\
\text { pastoris }\end{array}$ & (CHEN et al., 2017) \\
\hline XP_003664543.1 & M77CDH & $\begin{array}{l}\text { Thermothelomyces } \\
\text { thermophila }\end{array}$ & Ascomiceto & $\begin{array}{c}\text { Aspergillus } \\
\text { nidulans } \\
\text { A773 }\end{array}$ & Esse trabalho \\
\hline
\end{tabular}

Fonte: Arquivo próprio.

Nota: $\boldsymbol{a}^{*}$ indica CDHs que foram clonadas somente para confirmar sua identidade (sequenciamento) e não foram, posteriormente, produzidas homologamente ou heterologamente. 


\subsection{Classificação das CDHs}

A medida que as sequências gênicas das CDHs de fungos basidiomicetos e ascomicetos foram sendo descobertas e as proteínas estudadas do ponto de vista bioquímico e estrutural, as CDHs passaram a ser divididas em Classes I e II, englobando CDHs de basidiomicetos e de ascomicetos, respectivamente (HARREITHER et al., 2011). As CDHs da Classe I tendem a ter sequências de aminoácidos menores e não conter domínios de ligação a carboidratos (CBM). Por outro lado, CDHs da Classe II contém sequências maiores e mais complexas, apresentando ou não CBM (ZÁMOCKY et al., 2006). Em 2008, inseriuse uma nova classificação, a Classe III. Essa classificação foi baseada nas sequências de CDH hipotéticas de ascomicetos, obtidas do sequenciamento genômico desses fungos, porém sem nenhuma confirmação experimental das suas propriedades catalíticas (ZÁMOCKY et al., 2008)

Algumas características interessantes são que as CDHs da Classe I são bastante seletivas em relação ao substrato, atuando favoravelmente em celodextrinas e lactose (CDHs com a aplicação em biosensores de lactose). Ao contrário, as CDHs da Classe II apresentam um espectro de substrato muito maior, utilizando como substratos mono-, di- e oligossacarídeos (como arabinose, xilose, glucosamina, glicose, manose e manodextrinas) (LUDWIG et al., 2010).

Nos últimos anos, a Classe II recebeu uma subclassificação em Classe IIA e Classe IIB. Essa classificação levou em consideração as sequências e dados bioquímicos de CDHs, obtidos do estudo de diferentes linhagens de ascomicetos. As CDHs da Classe IIA são caracterizadas por conter um módulo de ligação a carboidrato (CBM) em sua porção $C$ terminal, enquanto as da Classe IIB não apresentam o CBM em sua estrutura (HARREITHER et al., 2011). De acordo com Harreither et al. (2011), a Classe IIB possui uma menor especificidade por substratos em relação a Classe IIA, significando que oxida mono-, di- ou oligômeros de hemicelulose com menor discriminação, enquanto que a Classe IIA tem tendência à maior especificidade por celobiose.

\subsection{Expressão da celobiose desidrogenase (M77CDH) em A. nidulans A773}

Diversos microrganismos procariotos e eucariotos já foram utilizados para expressar CDHs recombinantes (MA et al., 2017). Dentre eles, o mais empregado é a levedura Pichia pastoris, pelo fato de atingir altos níveis de expressão, manipulação em larga escala bem estabelecida e modificação genética bastante difundida. Porém, foi observado que as CDHs 
produzidas nos organismos naturais tinham uma maior atividade específica em relação a respectiva $\mathrm{CDH}$ produzida em $P$. pastoris. Essa discrepância foi atribuída, entre outras coisas, a super glicosilação. Já foi reportado que as CDHs possuem uma faixa de glicosilação entre 2\% (SCHOU; CHRISTENSEN; SCHULEIN, 1998) a 15\% (BAMINGER et al., 2001) da massa total de proteína, e o uso de $P$. pastoris como sistema de expressão pode inserir entre 10 a $48 \%$ de estruturas ricas em maltose como $N$-glicosilações (MA et al., 2017). Diante disso, a porcentagem de glicosilações feita pela $P$. pastoris pode interferir na transferência de elétrons intramolecular da $\mathrm{CDH}$, afetando seu desempenho (MA et al., 2017).

A E. coli apesar de ser o chassi de expressão e produção de enzimas mais utilizado na indústria, não é um bom sistema para a expressão para as CDHs. Isso ocorre pela ausência de uma maquinaria celular para realizar modificações pós-traducionais em proteínas em $E$. coli, algo indispensável para enzimas de eucariotos. Esta hipótese foi confirmada no estudo de Ma et al. (2017), em que a E. coli não foi capaz de produzir a CDH intacta (com domínios CYT e DH), apenas expressou o domínio DH da CDH.

Algumas espécies de fungos filamentosos como A. niger, A. oryzae e Trichoderma reesei também já foram utilizadas para expressão heteróloga da $\mathrm{CDH}$, porém poucas caracterizações destas enzimas foram realizadas (LANGSTON et al., 2012; MA et al., 2017; TURBE-DOAN et al., 2013).

Por fim, um estudo comparando os sistemas de expressão utilizando bactéria, levedura e fungo filamentoso para $\mathrm{CDH}$ concluiu que dentre estes sistemas, o fungo filamentoso demonstrou ser o chassi de produção mais eficiente para $\mathrm{CDH}$ recombinantes. Os fungos filamentosos $T$. reesei e A. niger foram capazes de produzir a CDH intacta, apresentando com níveis de glicosilação e atividade específica similares ao organismo de origem, portanto uma $\mathrm{CDH}$ que permite estudos bioquímicos e estruturais de alta qualidade (MA et al., 2017). No presente trabalho, a CDH proveniente do fungo termofílico $T$. thermophila foi clonada no vetor de expressão pEXPYR e expressa no fungo A. nidulans linhagem A773. Este sistema vem sendo utilizado por vários grupos de pesquisa e se mostrou eficiente para expressão heteróloga de várias proteínas (DAMÁSIO et al., 2011, 2012a, 2012b; MÜLLER et al., 2014; PARDO-PLANAS; PRADE; WILKINS, 2016). 


\subsection{Aplicações dos ácidos aldônicos de oligossacarídeos}

Ácidos aldônicos de oligossacarídeos são compostos de um monômero (ou mais) de um carboidrato ligado a um ácido aldônico. Os ácidos aldônicos de oligossacarídeos tem uma série de aplicações para a indústria de produtos voltados ao cuidado pessoal, como para cremes utilizados na hidratação de pele seca, redução de algumas irritações e inflamações na pele, tratamento e prevenção de envelhecimento da pele. Em formulações, pode ser utilizado em cosméticos para cabelos, unhas e pele, para tratamentos de danos pela exposição à luz solar, radiação, poluição, vento, frio, calor excessivo, químicos, entre outros. Há também aplicação em produtos para tratamento de feridas na pele ou nas vias oral, nasal e vaginal, ajudando na cicatrização de cortes, queimaduras e perfurações. Também deve-se considerar a vantagem de que a mistura de ácidos aldônicos de diferentes oligossacarídeos em produtos cosméticos e farmacêuticos pode potencializar os efeitos do produto e terem um efeito sinérgico (YU; SCOTT, 2002).

Além disso, o ácido celobiônico produzido pela $\mathrm{CDH}$ pode ser utilizado para produção de combustíveis (etanol, isobutanol) e compostos químicos por meio de processos fermentativos de microrganismos geneticamente modificados, como no caso da $E$. coli KO11 a qual foi capacitada para utilizar gluconato para produção de isobutanol (DESAI et al., 2015; HILDEBRAND et al., 2016). A manipulação genética da industrialmente importante Saccharomyces cerevisiae para consumo do ácido celobiônico foi feita nos estudos de Li et al. (2015). Nesse estudo inseriram a via de utilização de ácidos aldônicos de N. crassa em S. cerevisiae, possibilitando a transformação do ácido celobiônico em 6fosfogluconato, participando da via pentose fosfato e posterior entrada na glicólise (LI et al., 2015). Portanto, os ácidos aldônicos de oligossacarídeos, como o glucônico e celobiônico, e seus derivados possuem uma vasta aplicação na indústria alimentícia, farmacêutica e em produtos de higiene (RAMACHANDRAN et al., 2006). 


\section{OBJETIVOS}

\subsection{Objetivos gerais}

O objetivo deste trabalho foi a produção heteróloga, purificação e caracterização bioquímica e biofísica da enzima oxidativa celobiose desidrogenase (M77CDH), proveniente do fungo termofílico $T$. thermophila. Também se analisou a sacarificação de bagaço de cana e PASC através da suplementação de coquetéis enzimáticos com M77CDH, visando observar o efeito da adição da $\mathrm{M} 77 \mathrm{CDH}$ na conversão da biomassa e na produção de ácido celobiônico.

\subsection{Objetivos específicos}

a) Produção heteróloga da proteína de interesse (M77CDH);

b) Purificação da proteína recombinante;

c) Caracterização bioquímica (determinação de pH e temperatura ótimos, estabilidade térmica, estabilidade ao $\mathrm{pH}$, efeito de íons e compostos químicos, cinética enzimática e liberação do produto ácido celobiônico) e biofísica (dicroísmo circular e SAXS) da proteína obtida;

d) Avaliação do efeito da suplementação da $\mathrm{M} 77 \mathrm{CDH}$ no coquetel enzimático preparado a partir do fungo termofílico A. niveus na sacarificação de bagaço de cana pré-tratado por LHW utilizando DNS como método de identificação de açúcares;

e) Avaliação do efeito da suplementação da M77CDH no coquetel enzimático comercial Celluclast ${ }^{\circledR}$ adicionado de LPMO para sacarificação de PASC, utilizando HPAEC para identificação de açúcares e ácidos aldônicos obtidos. 


\section{METODOLOGIA}

\subsection{Linhagens dos fungos utilizados}

Neste trabalho foram utilizadas as linhagens de Aspergillus nidulans A773 (pyrG89; wA3; pyroA4), adquirida no Fungal Genetic Stock Center, de Thermothelomyces thermophila M77 ATCC 42464 (ou Myceliophthora thermophila M77), adquirido do American Type Culture Collection (ATCC) e de Aspergillus niveus RP-40, o qual foi gentilmente cedido pelo Prof. Dr. Rolf A. Prade da Oklahoma State University (Stillwater, OK, EUA) (Acesso PRJNA237468).

\subsection{Análise filogenética}

As sequências de proteínas celobioses desidrogenases utilizadas no alinhamento foram obtidas de Harreither et al. (2011) e do banco de dados do UniProt (Universal Protein Resource), utilizando a ferramenta BLAST com parâmetros padrão (https://www.uniprot.org/blast/; BATEMAN et al., 2017). A análise dos domínios catalíticos das sequências de CDH obtidas foi realizada pelo servidor Pfam versão 31.0 (FINN et al., 2016). O alinhamento múltiplo de 32 sequências de proteínas celobiose desidrogenases de basidiomicetos e ascomicetos foi realizado utilizando-se o servidor ClustalX 2.1 (JEANMOUGIN et al., 1998). A construção da árvore filogenética foi feita pelo programa MEGA7 (Molecular Evolutionary Genetics Analysis), utilizando o método de Minimun evolution, bootstrap de 1000 replicatas e modelo de substituição por Jones-Taylor-Thornton (TJJ). O SWISS-MODEL (WATERHOUSE et al., 2018) foi utilizado para predizer as estruturas secundárias e realizar o alinhamento com modelos cristalográficos para identificação de aminoácidos importantes.

As etapas seguintes, contidas no item 4.3, se referem a clonagem do gene e transformação em bactéria e transformação de protoplastos mediado por PEG. Contudo, esses passos não foram realizados neste trabalho, e sim, foi feito pelo grupo de pesquisa do Laboratório de Biologia Sintética e Molecular (SyMB Lab - EEL/USP). Como os dados não estão publicados e para maior entendimento do trabalho, decidiu-se inserir toda a metodologia referente à obtenção do fungo transformante com expressão heteróloga da M77CDH. 


\subsection{Clonagem, expressão e secreção da M77CDH}

\subsubsection{Construção dos oligonucleotídeos}

A sequência do gene codificando a M77CDH (XM_003664495), em que o peptídeo sinal foi identificado (NIELSEN, 2017) e mantido na sequência, foi utilizada para a construção dos oligonucleotídeos (primers). Localizou-se os trinta nucleotídeos iniciais e finais, presentes na região 5'- 3' do gene. O primer reverse foi construído utilizando o software Reverse Complement (www.bioinformatics.org/sms/index.html) e as sequências obtidas foram analisadas pelo OligoAnalyzer 3.1 (https://www.idtdna.com/calc/analyzer), em que é possível ajustar a temperatura de melting $\left(\mathrm{T}_{\mathrm{m}}\right)$ do oligonucleotídeo, e os parâmetros foram comprimento dos oligonucleotídeos maior que $20 \mathrm{pb}$ e diferença de $\mathrm{T}_{\mathrm{m}}$ menor que 3 ${ }^{\circ} \mathrm{C}$ entre os primers forward e reverse. Por fim, foram adicionadas sequências específicas aos oligonucleotídeos construídos para recombinação homóloga ao vetor em condições in vitro (Gibson Assembly).

\subsubsection{Extração do DNA genômico}

A extração do DNA genômico (DNAg) iniciou-se inoculando esporos do fungo $T$. thermophila em $200 \mathrm{ml}$ de meio de Mandels líquido (Apêndice A), foram mantidos a $45^{\circ} \mathrm{C}$ sob agitação a $180 \mathrm{rpm}$ durante 36 horas. Em seguida, os micélios foram separados por filtração e macerados em cadinhos de porcelana, adicionando nitrogênio líquido. Foi pesado $50 \mathrm{mg}$ do macerado para ser utilizado no processo de extração do DNAg com o Kit de purificação de DNA genômico Wizard (Promega ${ }^{\circledR}$ ) seguindo as especificações do fabricante.

\subsubsection{Amplificação do gene codificando M77CDH e do vetor $\mathrm{pEXPYR}$}

A amplificação do gene foi realizada pela técnica de PCR (Polymerase Chain Reaction), utilizando a enzima DNA polimerase Phusion $^{\mathrm{TM}}$ (New England BioLabs $\left.{ }^{\circledR}\right)$. As condições das reações de PCR estão de acordo com a Tabela 2, e foi utilizado 25 ciclos para a reação, sendo que o ciclo foi baseado em $98^{\circ} \mathrm{C}$ por $10 \mathrm{~s}, 68^{\circ} \mathrm{C}$ por $30 \mathrm{~s}, 72^{\circ} \mathrm{C}$ por 1 min $\mathrm{e} 72^{\circ} \mathrm{C}$ por mais $5 \mathrm{~min}$. $\mathrm{O}$ produto de $\mathrm{PCR}$ foi analisado por eletroforese em gel de agarose $1 \%(\mathrm{~m} / \mathrm{v})$, utilizando como padrão o marcador GeneRuler $1 \mathrm{~Kb}$ plus DNA Ladder (Thermo Fisher Scientific). 
Tabela 2 - Reagentes utilizados na reação de PCR para amplificação gênica.

\begin{tabular}{lc}
\hline \multicolumn{1}{c}{ Reagentes } & Volume $(\boldsymbol{\mu l})$ \\
\hline DNAg & 1 \\
Primer Forward & 2 \\
Primer Reverse & 2 \\
dNTPs & 2 \\
DMSO & 2 \\
$\mathrm{MgCl}_{2}$ & 0,5 \\
Phusion pol. & 0,5 \\
Tampão & 10 \\
Água Miliq & 30 \\
\hline
\end{tabular}

Fonte: Arquivo próprio.

O vetor pEXPYR (Figura 10) foi utilizado para a super-expressão e secreção da proteína de interesse no fungo filamentoso A. nidulans A773. Características importantes do vetor são que contém marcas de seleção que conferem resistência a ampicilina (AMP) e zeocina (ZEO), promotor da glucoamilase de A. niger (glaAP) para indução da expressão gênica por maltose, seguido por uma região $N$-terminal, que contém o peptídeo sinal e o terminador triptofano $(\operatorname{trp} C t)$. Além disso, o vetor contém uma marca de reversão de auxotrofia composta pelo gene que codifica a orotidina- $5^{\prime}$-monofosfato descarboxilase (pyrG) de A. niger. Esta enzima é fundamental para a biossíntese de pirimidinas e a presença deste gene no vetor é utilizado para reverter a linhagem auxotrófica de A. nidulans A773 (pyrG-) (SEGATO et al., 2012). Foi necessário a linearização e amplificação do vetor pEXPYR por meio da técnica de PCR para a o aumento do número de cópias e prosseguir para a etapa de construção do plasmídeo.

Figura 10 - Esquema representando regiões do vetor pEXPYR.

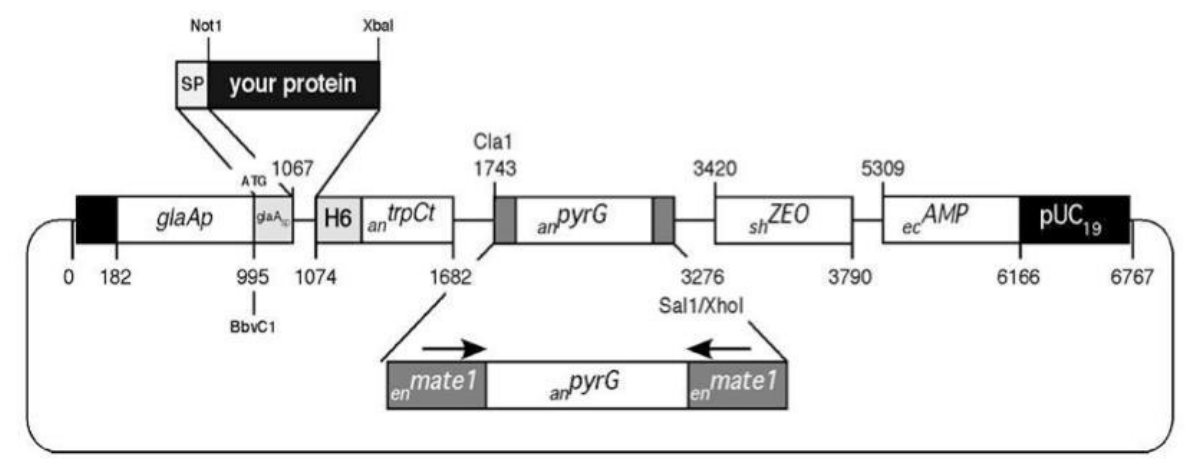

Fonte: Adaptado de (SEGATO et al., 2012). 


\subsubsection{Construção dos plasmídeos}

Para a construção dos plasmídeos (gene M77CDH + vetor pEXPYR) foi utilizada a metodologia de Gibson Assembly (GIBSON, 2011). A reação de Gibson foi composta de 4 $\mu \mathrm{L}$ do DNA codificando a M77CDH, $2 \mu \mathrm{L}$ de vetor $(25 \mathrm{ng} / \mu \mathrm{L})$ e $5 \mu \mathrm{L}$ de master mix Gibson Assembly (GA) (New England Biolabs ${ }^{\circledR}$ ). As reações foram incubadas por uma hora a $50^{\circ} \mathrm{C}$. O master mix GA é composto por 5'-T5 exonuclease, que remove as extremidades no sentido 5' $\rightarrow$ 3', Phusion $^{\circledR}$ DNA polimerase, que preenche os gaps deixados pela enzima T5 e Taq DNA ligase, que promove a ligação entre as regiões homólogas (GIBSON, 2011).

\subsubsection{Transformação bacteriana}

A transformação bacteriana foi realizada utilizando a metodologia de choquetérmico, com células quimio-competentes de E. coli Turbo (New England Biolabs ${ }^{\circledR}$ ). As células de E. coli Turbo em $100 \mu \mathrm{L}$ de meio SOC (Anexo B) foram descongeladas em banho de gelo e misturadas com o produto da reação do Gibson Assembly (aprox. $11 \mu \mathrm{L}$ do plasmídeo), em que foi mantida em banho de gelo por 30 minutos. Em seguida, a reação foi submetida ao choque térmico em banho-maria a $42^{\circ} \mathrm{C}$ por 45 segundos. As células foram imediatamente transferidas para o banho de gelo por mais 2 minutos. Após esse tempo, foi adicionado $1 \mathrm{ml}$ de meio SOC e foram incubadas a $37^{\circ} \mathrm{C}$ por 1 hora sob agitação de $200 \mathrm{rpm}$. Após, o cultivo foi centrifugado a $13.000 \mathrm{rpm}$ por 1 minuto e o excesso de sobrenadante foi descartado. A amostra remanescente (aprox. $100 \mu \mathrm{L}$ ) foi transferida para placas de Petri contendo meio LB (Anexo B) sólido contendo $100 \mu \mathrm{g} / \mathrm{ml}$ de ampicilina. Por fim, as placas foram incubadas por 18 horas a $37^{\circ} \mathrm{C}$. As colônias que cresceram no meio de seleção foram submetidas ao PCR de colônia.

\subsubsection{Purificação dos plasmídeos}

As colônias bacterianas positivas no PCR de colônia foram reservadas e um volume

de $9 \mu \mathrm{L}$ da suspensão celular foi inoculado em $10 \mathrm{ml}$ de meio LB líquido (contendo 100 $\mu \mathrm{g} / \mathrm{ml}$ de ampicilina) e cultivado por 16 horas a $200 \mathrm{rpm}$ e $37^{\circ} \mathrm{C}$. Após, as células foram submetidas a centrifugação a $13.000 \mathrm{rpm}$ por 5 minutos. $\mathrm{O}$ pellet formado foi submetido a extração e purificação dos plasmídeos utilizando-se o kit Wizard® Plus SV Minipreps DNA Purification Systems (Promega) seguindo as especificações do fabricante. 


\subsubsection{Preparação de protoplastos}

Preparou-se uma suspensão de esporos do fungo A. nidulans A773 (10 ${ }^{8}$ esporos $\left./ \mathrm{ml}\right)$ e $20 \mu \mathrm{l}$ foram inoculados em $250 \mathrm{ml}$ de meio mínimo $\mathrm{pH}$ 6,5 suplementado com uracila, uridina $\left(2,5 \mathrm{mg} / \mathrm{L}\right.$ de cada) e piridoxina $(1 \mathrm{mg} / \mathrm{L})$ (Anexo B). O cultivo foi mantido a $37^{\circ} \mathrm{C}$ sob agitação (180 rpm) por 18 horas. Os esporos e micélio produzidos foram recuperados por filtração em papel de filtro Whatman $\mathrm{n}^{\circ}$ 1, lavados com solução de $\mathrm{MgSO}_{4}$ 0,6 $\mathrm{M} \mathrm{e}$ transferidos para um tubo cônico estéril de $50 \mathrm{ml}$ contendo $10 \mathrm{ml}$ de DSPS pH 5,8 (Double Strength Protoplasting Solution: $\mathrm{KCl}$ 1,1M, ácido cítrico 0,1M), acrescido das enzimas: 200 mg de Lysing enzymes from Trichoderma harzianum (Sigma L1412), $100 \mathrm{mg}$ de Lysozyme from Chicken Egg White (Sigma L6876). A mistura foi incubada a $32^{\circ} \mathrm{C}$, sob agitação a 180 rpm, por aproximadamente 3 horas até adquirir a consistência de uma solução completamente líquida. Os protoplastos obtidos foram filtrados em membrana Miracloth (Calbiochem), lavados com $150 \mathrm{ml}$ de STC50 (Sorbitol 1,2 M, CaCl2 $50 \mathrm{mM}$, Tris $50 \mathrm{mM}$, $\mathrm{pH} 7,5$, autoclavado e mantido a $4{ }^{\circ} \mathrm{C}$ ) e centrifugados a $4500 \mathrm{rpm}$ a $4{ }^{\circ} \mathrm{C}$ por $10 \mathrm{~min}$. Por fim, o pellet resultante foi ressuspendido em $1 \mathrm{ml}$ de STC 50 e os protoplastos obtidos foram utilizados na etapa de transformação.

\subsubsection{Transformação dos protoplastos mediado por PEG}

A transformação do fungo A. nidulans A773 com o plasmídeo obtido foi feito pelo método de transformação mediado por polietilenoglicol (PEG). Adicionou-se cerca de $6 \mu \mathrm{g}$ do plasmídeo a um tubo estéril contendo $250 \mu \mathrm{L}$ da solução de protoplastos obtidos anteriormente e a mistura foi mantida à temperatura ambiente por $15 \mathrm{~min}$. Em seguida, foi adicionado $2 \mathrm{ml}$ de solução PEG 60\% (6 g de polietilenoglicol 4000, dissolvidos em $10 \mathrm{ml}$ de STC 50, em micro-ondas). A solução foi incubada à temperatura ambiente por 20 min, para o PEG induzir a fusão dos protoplastos e permitir a internalização dos plasmídeos nos protoplastos (KUWANO; SHIRATAKI; ITOH, 2008). Por fim, adicionou-se $10 \mathrm{ml} \mathrm{de}$ solução STC50 e transferiu-se alíquotas de $2 \mathrm{ml}$ para placas de Petri contendo meio de regeneração (meio mínimo adicionado de sorbitol 1,2 $\mathrm{M}$ e piridoxina $1 \mathrm{mg} / \mathrm{L}$ ), em que os transformantes foram selecionados pela reversão da marca auxotrófica $p y r G$ promovida pela inserção do plasmídeo no transformante. As placas foram incubadas a $37^{\circ} \mathrm{C}$ por 72 horas para o crescimento dos transformantes. 


\subsubsection{Screening das colônias transformantes de $A$. nidulans}

Os esporos das colônias transformantes foram inoculados em placas de Petri com 10 $\mathrm{ml}$ de meio mínimo contendo $5 \%$ de maltose (com piridoxina) e mantidos a $37^{\circ} \mathrm{C}$ por 48 horas. Após este período, os extratos foram concentrados 20 vezes em tubos Vivaspin de ultra filtração (GE Healthcare), com membrana de corte de $10 \mathrm{kDa}$. Após, os níveis de secreção da proteína de interesse foram analisados em gel de SDS-PAGE 15\% e, posteriormente, corado com azul brilhante de Comassie (SHAPIRO; VIÑUELA; V. MAIZEL JR., 1967).

A partir do item 4.4 "Cultivo do transformante de A. nidulans para expressão da proteína de interesse", prossegue-se com o trabalho realizado durante o período do Mestrado.

\subsection{Cultivo do transformante de $\boldsymbol{A}$. nidulans para expressão da proteína de interesse}

Como comentado anteriormente, a metodologia utilizada para clonagem do gene que codifica a proteína M77CDH foi a de Gibson Assembly (GIBSON, 2009). A produção da proteína recombinante $\mathrm{M} 77 \mathrm{CDH}$ pela linhagem A. nidulans foi realizada em 15 placas de Petri contendo $30 \mathrm{ml}$ de meio mínimo suplementado (Anexo B) com $1 \mathrm{mg} / \mathrm{l}$ de piridoxina (volume total de $500 \mathrm{ml}$ de extrato bruto obtido) e 3\% de maltose (Merck), inoculados com $0,5 \mathrm{ml}$ de uma solução de esporos $10^{7} / \mathrm{ml}$ em cada placa e mantidos em meio estacionário a $37{ }^{\circ} \mathrm{C}$ durante 2 dias. Após, os cultivos foram filtrados em membrana Miracloth (Calbiochem) utilizando um funil de Buchner para remoção dos micélios. A atividade enzimática da $\mathrm{CDH}$ foi determinada de acordo com o item 4.9.1 da seção Metodologia.

\subsection{Confirmação da proteína por Espectrometria de Massas}

A confirmação da proteína de interesse foi realizada por meio de espectrometria de massas (LC-MS/MS). Essa etapa foi realizada no Laboratório de Espectrometria de Massa do Laboratório Nacional de Biociências (LNBio) do Centro Nacional de Pesquisas em Energia e Materiais (CNPEM, Campinas/SP). Para a análise por LC-MS/MS, $10 \mu \mathrm{g}$ do extrato enzimático concentrado a partir do cultivo do A. nidulans recombinante para a $\mathrm{CDH}$, foi aplicado em gel SDS-PAGE $15 \%$ e corado com azul brilhante de Comassie. A banda correspondente à $\mathrm{M} 77 \mathrm{CDH}$ foi excisada do gel e submetida a procedimentos seguindo o protocolo do LNBio (http://lnbio.cnpem.br/wp-content/uploads/2012/11/Protocolo-dedigest\%C3\%A3o-in-gel.pdf) adaptado de Shevchenko et al. (1996). 


\subsection{Purificação enzimática}

Primeiramente, $500 \mathrm{ml}$ do extrato bruto filtrado foi concentrado para um volume final de $50 \mathrm{ml}$ no aparato de ultrafiltração com agitação Amicon ${ }^{\circledR}$ Stirred Cell (Merck), a temperatura ambiente, utilizando uma membrana Biomax ${ }^{\circledR}$ (Merck-Millipore) com corte de $10 \mathrm{kDa}$. O extrato bruto concentrado foi dialisado utilizando tampão fosfato de sódio 50 $\mathrm{mM}, \mathrm{pH}$ 8,0, adicionado até completar o volume de $300 \mathrm{ml}$, e concentrou-se novamente em Amicon $^{\circledR}$ até um volume final de $25 \mathrm{ml}$. A etapa de diálise foi realizada para retirar o excesso de maltose presente no extrato bruto e corrigir o pH. Após, o concentrado contendo a M77CDH foi submetido a etapa de purificação em coluna de bancada contendo $5 \mathrm{ml}$ de resina DEAE-Sepharose ${ }^{\circledR}$ CL-6B (GE Healthcare) de troca aniônica com tampão fosfato de sódio $50 \mathrm{mM}$ pH 8,0 e adicionando gradiente salino de $\mathrm{NaCl}$ de 50 a $1000 \mathrm{mM}$ para eluição das proteínas. As amostras foram quantificadas pelo método de Bradford (BRADFORD, 1976) com soro-albumina bovina (BSA) como padrão (Figura 33B) e $20 \mu 1$ de cada fração eluída do gradiente salino foram analisadas por eletroforese em gel SDS-PAGE 15\%, aplicadas a uma voltagem de $120 \mathrm{~V}$ por cerca de 90 minutos. Após, o gel foi corado com azul brilhante de Comassie, e as frações contendo a proteína de interesse foram agrupadas (totalizando um volume de $30 \mathrm{ml}$ ) e concentradas em tubos Vivaspin ${ }^{\circledR} 20$ (GE Healthcare) com membrana de corte de $10 \mathrm{kDa}$ até um volume de $5 \mathrm{ml}$.

Após, o eluente concentrado da etapa de troca iônica foi injetado na coluna de exclusão de tamanho HiPrep 26/60 Sephacryl ${ }^{\circledR}$ S-100 (GE Healthcare) (faixa de separação ótima de proteínas entre 5 - $250 \mathrm{kDa}$ ), já equilibrada com tampão fosfato de sódio $50 \mathrm{mM}$ pH 8,0 e acoplada ao sistema Äkta Pure M25 (GE Healthcare). Nesse aparato o fluxo foi de 0,5 $\mathrm{ml} / \mathrm{min}$ e coletou-se frações de $1,5 \mathrm{ml}$. De acordo com o cromatograma obtido, selecionou-se as frações com maior absorbância a $280 \mathrm{~nm}$ e foram analisadas por eletroforese em gel SDS-PAGE 15\%, corado com azul brilhante de Comassie. As frações eluídas com presença da proteína $\mathrm{M} 77 \mathrm{CDH}$ foram reservadas para os futuros ensaios de atividade enzimática. Ao final, uma solução amarelada foi obtida, coloração característica para flavoproteínas (MA et al., 2017).

\subsection{Caracterização espectral}

A caracterização espectral da $\mathrm{M} 77 \mathrm{CDH}$ purificada foi realizada pela medição da absorbância na faixa de comprimento de onda de 300 a $650 \mathrm{~nm}$ em ambos estados oxidado e reduzido da M77CDH em espectrofotômetro Infinite ${ }^{\circledR} 200$ PRO (TECAN Life Sciences). 
Primeiramente, a M77CDH purificada foi diluída em tampão acetato de sódio 0,1 M, pH 4,5, até uma absorbância máxima de 2,5 a $280 \mathrm{~nm}$. O espectro da M77CDH oxidada foi obtido pela leitura da absorbância de $100 \mu \mathrm{l}$ da enzima purificada em $100 \mu \mathrm{l}$ de tampão acetato de sódio 0,1 M, com volume final de leitura de $200 \mu$ l. O espectro da M77CDH reduzida foi obtido adicionando grande excesso de solução de lactose 1 M ( 1000 vezes de excesso molar) em $100 \mu \mathrm{l}$ da M77CDH purificada com volume final de leitura de $200 \mu$ l, misturando-se bem e observou-se imediatamente o comportamento do espectro (BAMINGER et al., 1999; CANEVASCINI; BORER; DREYER, 1991).

\subsection{Ensaio de desglicosilação}

Neste ensaio uma amostra homogênea da enzima foi tratada com as enzimas Peptide$N$-glicosidase $F$ (PNGase F) (New England BioLabs ${ }^{\circledR}$ ), que realiza a clivagem de ligações entre $N$-acetilglicosamina e o aminoácido asparagina em glicoproteínas, e com Endoglicosidase H (Endo H) (New England BioLabs ${ }^{\circledR}$ ), que cliva estruturas de asparagina glicosilada com oligossacarídeos ricos em maltose e algumas estruturas híbridas de carboidratos com $N$-ligações (NEW ENGLAND BIOLABS, 2018). Cerca de $5 \mu \mathrm{g}$ da $\mathrm{M} 77 \mathrm{CDH}$ foram incubados com $1 \mu 1$ do Glycoprotein denaturing Buffer $10 \mathrm{x}$ a $100{ }^{\circ} \mathrm{C}$ por 10 min para desnaturação da proteína. Em seguida, as misturas reacionais (seguindo as instruções dos fabricantes) foram incubadas por 1 hora a $37^{\circ} \mathrm{C}$ e analisadas em gel de SDSPAGE $15 \%$ e coradas com azul brilhante de Comassie.

\subsection{Ensaios para caracterização bioquímica}

\subsubsection{Atividade enzimática}

Os ensaios enzimáticos foram feitos em condições descritas na literatura e adaptadas em nosso laboratório (BAMINGER et al., 2001; CANEVASCINI; BORER; DREYER, 1991; SULEJ et al., 2015), com volume total de reação de $200 \mu 1$ contendo $30 \mathrm{mM}$ de celobiose (dissolvida em água), 0,3 mM de DCIP (2,6-diclorofenol indofenol) (solução em água contendo $10 \% \mathrm{v} / \mathrm{v}$ de etanol $)\left(\varepsilon_{520}=6,8 \mathrm{mM}^{-1} \mathrm{~cm}^{-1}\right), 5 \mu 1$ da enzima M77CDH purificada $(0,55 \mathrm{mg} / \mathrm{ml})$ e volume suficiente de tampão citrato-fosfato-glicina $0,1 \mathrm{M}$ (ácido cítrico $100 \mathrm{mM}$, fosfato de sódio $100 \mathrm{mM}$ e glicina $100 \mathrm{mM}$ ). Nas reações utilizando o citocromo $c$ (cyt $c$ ) como aceptor de elétrons utilizou-se $20 \mu \mathrm{M}$ de citocromo $c$ de coração equino (Sigma-Aldrich) $\left(\varepsilon_{550}=19,6 \mathrm{mM}^{-1} \mathrm{~cm}^{-1}\right), 5 \mu 1$ da enzima M77CDH purificada, 10 $\mathrm{mM}$ de celobiose e tampão citrato-fosfato-glicina $0,1 \mathrm{M}$ até um volume final de reação de 
$200 \mu$ l. Uma unidade de atividade enzimática foi determinada como $1 \mu \mathrm{mol} \mathrm{min}^{-1}$ de DCIP ou citcromo $c$ reduzidos sob as condições de reação. O tempo total de reação foi determinado como sendo de 3 min (Apêndice C - Figura 32). As medições de absorbância foram realizadas no espectrofotômetro Infinite ${ }^{\circledR} 200$ PRO (TECAN Life Sciences) no comprimento de onda de $520 \mathrm{~nm}$ para o DCIP e $550 \mathrm{~nm}$ para o cyt $c$.

\subsection{2 pH ótimo e estabilidade}

A determinação do $\mathrm{pH}$ ótimo da $\mathrm{M} 77 \mathrm{CDH}$ foi feita com ensaios a temperatura de $30^{\circ} \mathrm{C}$ observando a redução da absorbância do aceptor de elétrons DCIP, de acordo com a atividade padrão descrita anteriormente (item 4.9.1), porém em tampão citrato-fosfatoglicina 0,1 M com valores de $\mathrm{pH}$ variando de 2 a 10. Para pHs acima de 6,5, o coeficiente de extinção molar do DCIP utilizado foi de $6,6 \mathrm{mM}^{-1} \mathrm{~cm}^{-1}$ (BAMINGER et al., 2001). A avaliação do $\mathrm{pH}$ ótimo também foi realizada com o aceptor de elétrons citocromo $c$, de acordo com as condições descritas no item 4.9.1, a $30{ }^{\circ} \mathrm{C}$, em tampão citrato-fosfato-glicina $0,1 \mathrm{M}$ e valores de $\mathrm{pH}$ variando entre 3 a 11,5. Todos os reagentes (exceto a enzima) tiverem sua temperatura equilibrada a $30{ }^{\circ} \mathrm{C}$ por $5 \mathrm{~min}$, e após, foram misturados e adicionados à enzima purificada. A absorbância no tempo zero foi determinada pela leitura da absorbância de todos os reagentes da reação, exceto pela adição de enzima.

A estabilidade ao $\mathrm{pH}$ foi realizada com a incubação da enzima em diferentes valores de $\mathrm{pH}(5,0 ; 6,0 ; 7,0$ e 8,0) em tampão citrato-fosfato-glicina $0,1 \mathrm{M}$ por diferentes tempos $\left(0,5 ; 1,5 ; 3,5\right.$ e 24 horas) a $30{ }^{\circ} \mathrm{C}$. A atividade residual foi medida somente para o aceptor de elétrons DCIP, na temperatura ótima previamente determinada de $65^{\circ} \mathrm{C}$ por $3 \mathrm{~min}$, em que ao término da reação as amostras foram colocadas em gelo e lidas imediatamente a $520 \mathrm{~nm}$.

\subsubsection{Temperatura ótima e estabilidade térmica}

Os testes de temperatura ótima foram realizados em mistura reacional no $\mathrm{pH}$ ótimo para o DCIP ( $\mathrm{pH} 5,5$ ) e com $5 \mu$ l da enzima M77CDH purificada e diluída 7 vezes $(0,4 \mu \mathrm{g})$, assim como no $\mathrm{pH}$ ótimo para o citocromo $c(\mathrm{pH} 7,0)$ com $3 \mu \mathrm{l}$ da $\mathrm{M} 77 \mathrm{CDH}$ diluída 20 vezes $(0,08 \mu \mathrm{g})$. Neste ensaio diluiu-se a enzima, pois em temperaturas acima de $30{ }^{\circ} \mathrm{C}$ a atividade enzimática era muito elevada e ajustou-se a concentração da enzima para que as reações fossem de $3 \mathrm{~min}$. As temperaturas de reação variaram na faixa de 30 a $80{ }^{\circ} \mathrm{C}$ (para o DCIP) e na faixa de 10 a $80{ }^{\circ} \mathrm{C}$ (para o cyt $c$ ) em intervalos de $10{ }^{\circ} \mathrm{C}$ em termociclador e em temperaturas próximas da ótima variou-se em $5^{\circ} \mathrm{C}$. Após o tempo total de reação as amostras 
foram colocadas em gelo e imediatamente lidas em espectrofotômetro no respectivo comprimento de onda para cada aceptor de elétrons.

A estabilidade térmica foi realizada pela incubação da enzima em diferentes temperaturas $\left(50,55,60\right.$ e $\left.65^{\circ} \mathrm{C}\right)$ por diferentes tempos $(0,25 ; 0,5 ; 1,5 ; 3 ; 5$ e 7,5 horas) em tampão acetato de sódio $0,1 \mathrm{M}, \mathrm{pH}$ 5,5. A reação da atividade residual foi medida com DCIP de acordo com o item 4.9.1, porém na temperatura e $\mathrm{pH}$ ótimos $\left(65^{\circ} \mathrm{C}\right.$ e $\left.\mathrm{pH} 5,5\right)$.

\subsubsection{Painel de íons e componentes químicos}

O ensaio com diferentes tipos de íons e componentes químicos foram realizados em tampão succinato $90 \mathrm{mM}$, celobiose a $30 \mathrm{mM}$, DCIP a $0,3 \mathrm{mM}$ adicionado da solução do respectivo íon ou composto químico a uma concentração final de $10 \mathrm{mM}$ do sal e $5 \mu \mathrm{l}$ da enzima M77CDH purificada e diluída 7 vezes $(0,4 \mu \mathrm{g})$. A reação ocorreu em condições ótimas de $\mathrm{pH}$ e temperatura $\left(65{ }^{\circ} \mathrm{C}\right.$ em $\left.\mathrm{pH} 5,5\right)$ e com DCIP. As soluções de íons e componentes químicos utilizados foram de $\mathrm{CaCl}_{2}, \mathrm{NaMoO}_{4}, \mathrm{MnCl}_{2}, \mathrm{ZnSO}_{4}, \mathrm{MgCl}_{2}, \mathrm{KCl}$, $\mathrm{NaH}_{2} \mathrm{PO}_{4}, \mathrm{NH}_{4} \mathrm{Cl}, \mathrm{KH}_{2} \mathrm{PO}_{4}, \mathrm{Na}_{2} \mathrm{SO}_{4}, \mathrm{NaCl}, \mathrm{CuSO}_{4}, \mathrm{CoCl}_{2}, \mathrm{FeCl}_{3}$, SDS, Etanol, EDTA. Os dois íons que apresentaram maior efeito positivo e os dois com maior efeito negativo na atividade enzimática relativa da $\mathrm{M} 77 \mathrm{CDH}$ foram ensaiados em diferentes concentrações finais, $\mathrm{MgCl}_{2}(1,5,10,15,20,30$ e $50 \mathrm{mM}), \mathrm{NaMoO}_{4}(1,10,15,30$ e $50 \mathrm{mM}), \mathrm{CuSO}_{4}(1$, 2, 3 e $5 \mathrm{mM})$ e $\mathrm{FeCl}_{3}(1,2,3$ e $4 \mathrm{mM})$ para averiguar a extensão do efeito na atividade da $\mathrm{M} 77 \mathrm{CDH}$.

\subsubsection{Cinética enzimática da M77CDH}

O ensaio para determinação dos parâmetros cinéticos da enzima $\mathrm{M} 77 \mathrm{CDH}$ foi realizado utilizando concentrações de celobiose entre $0,05 \mathrm{mM}$ a $2 \mathrm{mM}$ em tampão citratofosfato-glicina $\mathrm{pH} 5,5,3 \mu \mathrm{L}$ da enzima $\mathrm{CDH}$ purificada $(1,65 \mu \mathrm{g})$ e $0,3 \mathrm{mM}$ de DCIP. A cinética utilizando-se o aceptor de elétrons cyt $c(20 \mu \mathrm{M})$ foi realizada com celobiose $(0,005$ a $0,7 \mathrm{mM}$ ) em tampão acetato de sódio $0,1 \mathrm{mM}(\mathrm{pH} 4,5)$ e fosfato de sódio $0,1 \mathrm{mM}(\mathrm{pH} 7,5)$. A reação foi incubada em espectrofotômetro e foi analisada por $60 \mathrm{~s}$ para monitorar o decaimento da absorbância em $520 \mathrm{~nm}\left(\mathrm{DCIP}\right.$, a $30^{\circ} \mathrm{C}$ ) ou $550 \mathrm{~nm}\left(\mathrm{cyt} \mathrm{c}\right.$, a $\left.40^{\circ} \mathrm{C}\right)$. Os cálculos de atividade foram feitos utilizando-se o decaimento linear durante o primeiro minuto de reação. A temperatura de todos os reagentes foi previamente equilibrada durante 5 min na respectiva temperatura de ensaio. A curva de regressão não-linear dos valores de 
atividade enzimática e determinação dos parâmetros cinéticos $\left(\mathrm{V}_{\text {máx }}, \mathrm{k}_{\mathrm{m}} \mathrm{e} \mathrm{k}_{\mathrm{cat}}\right)$ foram feitos pelo software GraphPad Prism 7 (Graphpad Software).

\subsubsection{Reação com celobiose e celooligossacarídeos}

A reação com celobiose consistiu em 1,87 mM (cerca de $0,7 \mathrm{~g} / \mathrm{l}$ ) de celobiose em tampão fosfato de sódio a 50 mM (pH 6,0) e variando-se a concentração da enzima M77CDH em 0,5 e $2 \mu \mathrm{M}$ em um volume final da reação de $300 \mu 1$. O ensaio foi realizado a $50^{\circ} \mathrm{C}$ em ThermoMixer ${ }^{\circledR} \mathrm{R}$ (Eppendorf) a $850 \mathrm{rpm}$, retirando-se pontos em 2, 5, 10, 15 e $30 \mathrm{~min}$ e 1, $2,4,8$ e 16 horas. As reações foram encerradas com fervura a $99^{\circ} \mathrm{C}$ por $5 \mathrm{~min}$. As amostras foram centrifugadas a $14000 \mathrm{rpm}$ durante $15 \mathrm{~min}$ e congeladas para posterior análise em HPAEC (High-Performance Anion-Exchange Chromatography) acoplado a um detector amperométrico (PAD). Os brancos foram feitos somente contendo a celobiose ou somente a enzima. As reações foram feitas em duplicata.

A atividade relativa da $\mathrm{M} 77 \mathrm{CDH}$ nos diferentes celooligossacarídeos C3 (celotriose), C4 (celotetraose), C5 (celopentaose) e C6 (celohexaose) a $100 \mu \mathrm{M}$ de concentração final foi realizada a $40^{\circ} \mathrm{C}$, utilizando $0,3 \mathrm{mM}$ de DCIP, $0,3 \mu 1$ da $\mathrm{M} 77 \mathrm{CDH}$ purificada $(0,165 \mu \mathrm{g}) \mathrm{em}$ tampão acetato de sódio $50 \mathrm{mM}, \mathrm{pH} 5,5$, observando a redução de absorbância a $520 \mathrm{~nm}$ durante $60 \mathrm{~s}$.

\subsection{Dicroísmo circular}

O espectro de dicroísmo circular (CD, do inglês Circular Dichroism) na região do

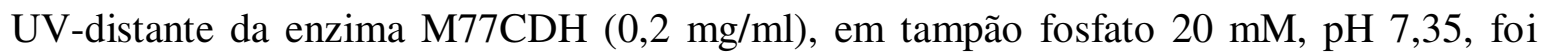
obtido em espectropolarímetro JASCO J-815 CD a $25{ }^{\circ} \mathrm{C}$ utilizando uma cubeta de $0,1 \mathrm{~cm}$ e comprimento de onda variando entre 190 a $270 \mathrm{~nm}$. Um total de seis espectros foram coletados para cada experimento e a média dos valores obtidos foi subtraída pelo valor do controle para gerar o espectro final. A análise do espectro ao longo do aumento da temperatura foi observada com o monitoramento da elipticidade a $222 \mathrm{~nm}$ variando-se a temperatura de $20{ }^{\circ} \mathrm{C}$ a $90{ }^{\circ} \mathrm{C}$. As análises de $\mathrm{CD}$ foram realizadas no Grupo de Biofísica Molecular Sérgio Mascarenhas no Departamento de Física e Ciência Interdisciplinar do Instituto de Física de São Carlos (IFSC/USP). 


\subsection{Espalhamento de Raios-X a baixos ângulos (SAXS)}

O mesmo tampão utilizado na purificação enzimática e a M77CDH na concentração de $3 \mathrm{mg} / \mathrm{ml}$ foram analisados pela linha de luz SAXS1 do Laboratório Nacional de Luz Síncrotron (LNLS), localizado no CNPEM em Campinas-SP, com exposições de 100 e 300 segundos para o tampão e 10 e 300 segundos para a enzima. O comprimento de onda da radiação foi de 1.48 Å e a detecção do espalhamento foi feito pelo equipamento Pilatus 300k a uma distância amostra-detector de 1022,5 mm e resultando em dados na faixa de 0,013 a 0,33 $\AA^{-1}$. O programa Fit2D (HAMMERSLEY, 2016) foi utilizado para integrar os padrões de espalhamento obtidos. O programa GNOM (SVERGUN, 1992) foi utilizado para ajustar os dados e avaliar a função $p(r)$ e com o DAMMIN (SVERGUN, 1999) para obtenção os modelos de baixa resolução por ab initio. O programa SUPCOMB (KOZIN; SVERGUN, 2001) realizou a sobreposição a estrutura modelada por homologia e o modelo médio a baixa resolução. Por fim, o Modeller foi utilizado para comparação de estruturas tridimensionais (WEBB; SALI, 2016). A construção do modelo foi realizada em colaboração com o Doutor Mário Tyago Murakami e o Dr. Plínio Salmazo.

\subsection{Sacarificação enzimática da biomassa utilizando extrato bruto de $A$. niveus suplementado com M77CDH}

\subsubsection{Bagaço de cana pré-tratado por Liquid Hot Water}

O bagaço de cana pré-tratado pelo método de Liquid Hot Water (LHW) foi cedido pelo Prof. Dr. Mark Wilkins da Universidade do Nebraska-Lincoln (NE, EUA). A condição do pré-tratamento por LHW foi uma suspensão da biomassa a 5,0\% (m/v) aquecida a 180 ${ }^{\circ} \mathrm{C}$ por $20 \mathrm{~min}$, com uma taxa de aquecimento de $1,0^{\circ} \mathrm{C} / \mathrm{min}$ utilizando um reator $4520 \mathrm{Bench}$ Top 1 L (Parr ${ }^{\circledR}$ Instrument Company).

\subsubsection{Obtenção do extrato enzimático de A. niveus RP-40}

Esporos de A. niveus RP-40 foram submetidos a uma etapa de pré-cultivo em $400 \mathrm{ml}$ de meio mínimo líquido (Anexo B) ( $\mathrm{pH}$ 6,5) dispostos em frasco Erlenmeyer de 2 L sob agitação de $160 \mathrm{rpm}$ a $45{ }^{\circ} \mathrm{C}$ durante 48 horas. Após, o conteúdo foi filtrado em papel de filtro Whatman $\mathrm{n}^{\circ} 1$ e lavado com $1000 \mathrm{ml}$ de água destilada autoclavada. Em seguida, a massa micelial foi transferida para $400 \mathrm{ml}$ de meio mínimo líquido, porém substituindo a glicose por $1 \%(\mathrm{~m} / \mathrm{v})$ de bagaço de cana in natura como única fonte de carbono (etapa de 
cultivo). A incubação foi mantida a $45^{\circ} \mathrm{C}$ por 24 horas e sob agitação de $200 \mathrm{rpm}$. Em seguida, o extrato enzimático obtido foi filtrado em membrana Miracloth (Calbiochem) e concentrado no sistema Amicon $^{\circledR}$ utilizando membrana Biomax ${ }^{\circledR}$ (corte de $10 \mathrm{kDa}$ ). A concentração final de proteínas obtidas do extrato enzimático concentrado do A. niveus foi de $74 \mathrm{mg} / \mathrm{ml}$.

\subsubsection{Condições da hidrólise enzimática}

Antes de iniciar a hidrólise enzimática a biomassa pré-tratada foi exaustivamente lavada com água destilada para remoção de açúcares residuais. As reações de hidrólise foram compostas de 1,0\% (m/v) de bagaço de cana pré-tratado por LHW durante $20 \mathrm{~min}(20 \mathrm{mg})$ em tampão acetato de sódio $50 \mathrm{mM}(\mathrm{pH} \mathrm{5,0),} 100 \mu \mathrm{g}$ de proteínas totais obtidas a partir do extrato bruto de A. niveus ( $5 \mathrm{mg} / \mathrm{g}$ substrato) e variando-se a adição de M77CDH purificada entre 0,05 a $50 \mu \mathrm{g}$, em um volume final de $2 \mathrm{ml}$ de reação. As reações foram incubadas por 24 horas a $50{ }^{\circ} \mathrm{C}$, em agitação a $140 \mathrm{rpm}$. Após, as amostras foram centrifugadas a $4000 \mathrm{rpm}$ a $10{ }^{\circ} \mathrm{C}$ durante 15 min e o sobrenadante foi reservado para análise de quantidade de açúcar redutor. A liberação de açúcares redutores foi detectada pelo método de DNS (MILLER, 1959) e a quantidade de açúcares liberados foi determinada de acordo com a curva padrão de glicose (Apêndice D - Figura 33B). Os ensaios foram feitos em triplicata, a reação somente com a biomassa em tampão foi adotada como branco e o ensaio contendo biomassa, tampão e extrato do A. niveus foi adotado como controle (100\%).

\subsection{Sacarificação enzimática do PASC utilizando coquetel comercial suplementado com LPMO e M77CDH}

O substrato sintético PASC $(1 \% \mathrm{~m} / \mathrm{v})$ foi utilizado como substrato para ensaio de sacarificação, utilizando-se o coquetel enzimático comercial Celluclast ${ }^{\circledR} \quad(9$ FPU/g substrato), LPMO de origem bacteriana $(1 \mu \mathrm{M})$ e suplementado com a enzima M77CDH em diferentes concentrações $(0,5$ e 2,0 $\mu \mathrm{M})$ em tampão acetato de sódio (50 mM e pH 5,0) em volume final de $1 \mathrm{ml}$ de reação a $50{ }^{\circ} \mathrm{C}$ e agitação de $200 \mathrm{rpm}$ durante 20 horas. Quando necessário, foi adicionado ácido ascórbico $(1 \mathrm{mM})$ com doador de elétrons para a LPMO. As reações foram encerradas com fervura a $99{ }^{\circ} \mathrm{C}$ por $5 \mathrm{~min}$. As amostras foram centrifugadas a $14000 \mathrm{rpm}$ durante $15 \mathrm{~min}$ e o sobrenadante foi congelado para posterior análise em HPAEC. 


\section{RESULTADOS E DISCUSSÃO}

\subsection{Análise da sequência da M77CDH}

A sequência de aminoácidos da M77CDH foi analisada pela base de dados do Pfam (FINN et al., 2016), em que foi predito que a enzima apresenta um peptídeo sinal entre os aminoácidos 1 e 23 (resultado similar ao obtido pela análise no servidor SignalP 4.1). A proteína apresenta a região $\mathrm{CDH}$-cyt entre os aminoácidos 30 e 218 que corresponde ao domínio citocromo; uma sequência de peptídeos rica em treonina e serina (Thr-Ser) que conecta (linker) os domínios CYT e DH; e o domínio DH, que contém os subdomínios GMC (família de glicose-metanol-colina oxidorredutases) $N$-terminal (entre 249-550) e $C$-terminal (642-778) (Figura 11). O subdomínio $N$-terminal é bastante conservado na família GMC sendo reconhecido por ser o sítio de ligação do cofator FAD, já o subdomínio C-terminal é responsável pela ligação ao substrato, quando o substrato está presente no sítio catalítico (HALLBERG et al., 2002).

Figura 11 - Esquema identificando as regiões de peptídeo sinal (sp), linker e os domínios CYT e DH da $\mathrm{M} 77 \mathrm{CDH}$.

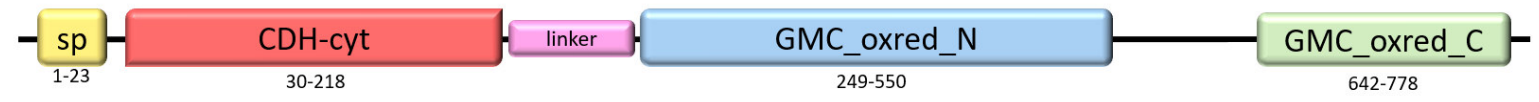

Fonte: Arquivo próprio.

Nota: CDH-cyt: domínio citocromo.

GMC_oxred_N e GMC_oxred_C: indicam domínio desidrogenase.

A sequência da M77CDH também foi analisada pelo servidor SWISS-MODEL (WATERHOUSE et al., 2018) e os resultados mostraram uma maior identidade $(60,9 \%)$ da M77CDH com a CDH de Myriococcum thermophilum (MtCDH) (TAN et al., 2015), a qual já é bem caracterizada e possui a sua estrutura determinada por técnica de cristalografia (HALLBERG et al., 2002; TAN et al., 2015). Com base no alinhamento obtido (Figura 12) foi possível identificar aminoácidos, como o Trp291, que é capaz de interagir com a extremidade não redutora do resíduo de glicosil do substrato (no subsítio B de ligação ao substrato), os aminoácidos Tyr614 e Asn695, que tem funções de estabilização do estado de transição da celobiose durante a oxidação (no substítio C de catálise do substrato) e a Met305, importante para a associação do domínio CYT e DH. Os aminoácidos catalíticos His696 e Asn745 também foram identificados na M77CDH através do alinhamento (Figura 12) (TAN et al., 2015). 
Figura 12 - Alinhamento entre as sequências de aminoácidos da M77CDH e MtCDH (M. thermophilum).

M77CDH

M. therm.

M77CDH

M. therm.

M77CDH

M. therm.

$\mathrm{M} 77 \mathrm{CDH}$

M. therm.

M77CDH

M. therm.

M77CDH

M. therm.

M77CDH

M. therm.

M77CDH

M. therm.

M77CDH

M. therm.

M77CDH

M. therm.

M77CDH

M. therm.

M77CDH

M. therm.

M77CDH

M. therm.
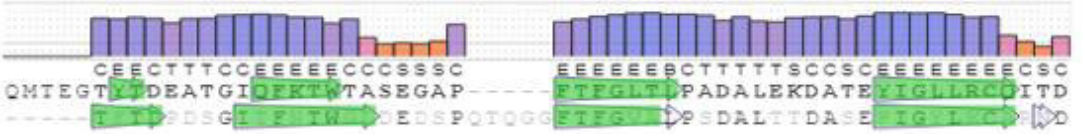

EEEEEESCTTTTSCCSCEEEEEEEECSC

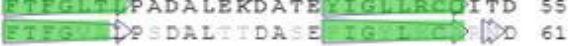

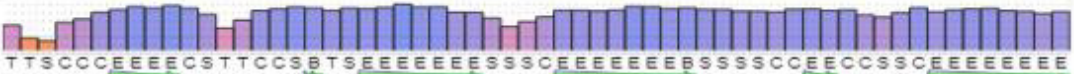

PASPSWCGISHGOSGOMTOALLLVAWASEDTVYTSERYATGYTLPGHTGDAKLTOISSS 115

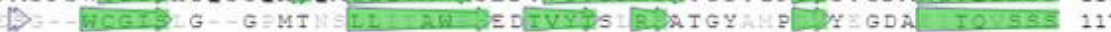

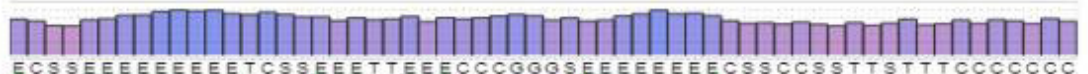

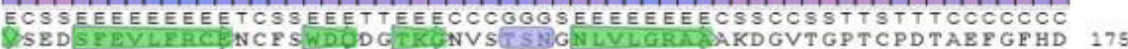

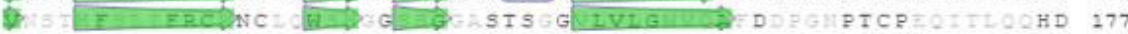

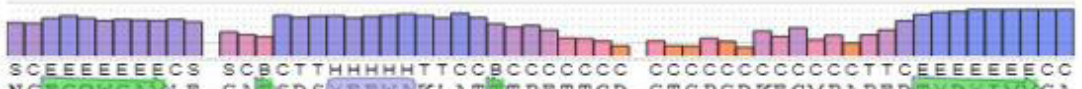

SCEEEEEEECS SCBCTTHHHHHTTCCBCCCCCCC CCCCCCCCCCCCTTCEEEEEEECC

NGE GOWGANLE-GAPSDSYEEWAKLATPTPETTCD-GTGPGDKECVPAPEDTYD ITVNGA 233

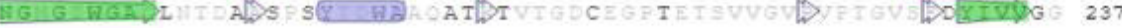

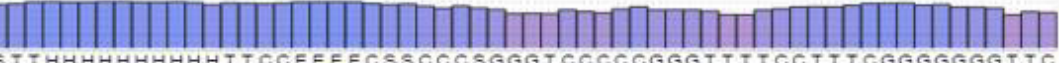
STTHHHHHHHHHHTTCCEEEECSSCCCSGGGTCCCCCGGGTT TTCCTYTCOGOGGOGT'C 293

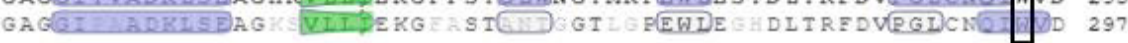

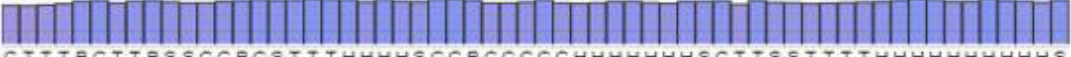
SAGI TCTDYSOMACSTTTHHHHSCCBCCCOCHHHHHHHSCT SSTTTTHHHHHAHHHHS 35

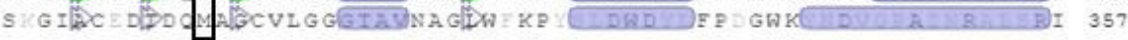

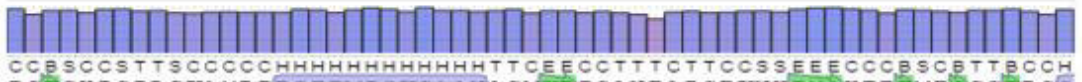

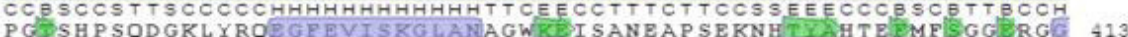

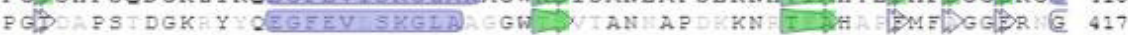

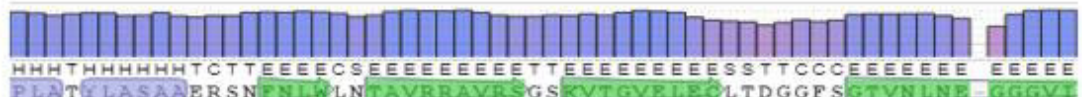

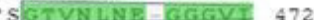

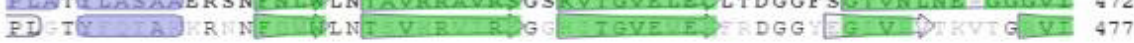

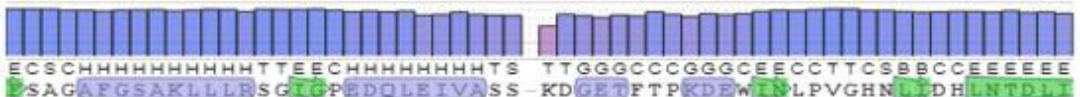

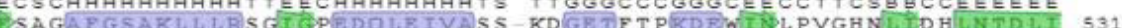

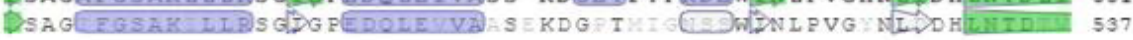

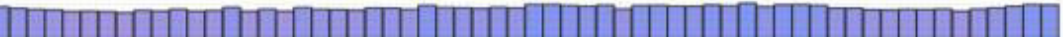

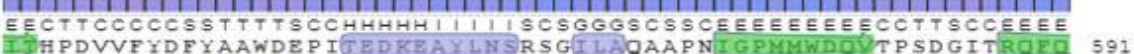

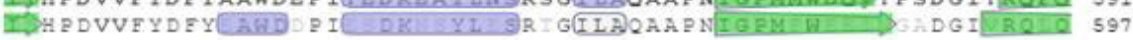

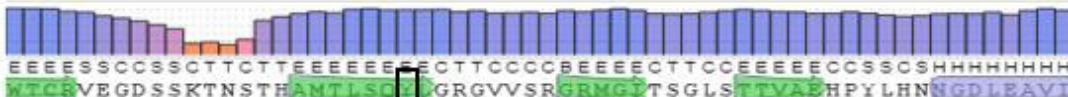
EEEESSCOSSCTTCTTEEEEEEREOTTCCOCBEEEECTTCOEEEEECCSSOSHHHHHHHH

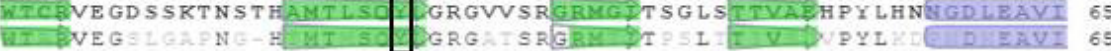

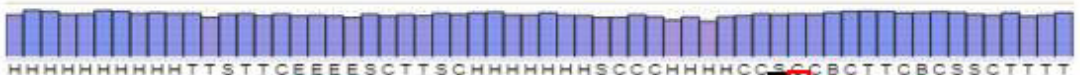
НHНHНHНHНHTTSTTCEEEESCTTSCHHHHHHHSCOCHHHHCCSOGBCTTCBCSSCTTTT

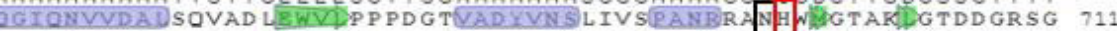

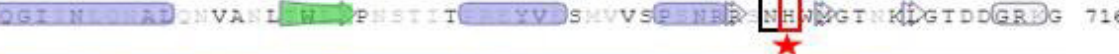

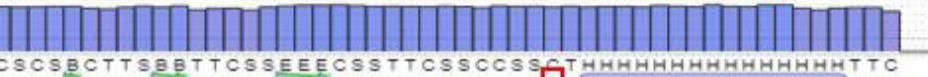

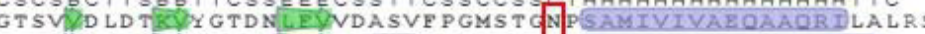

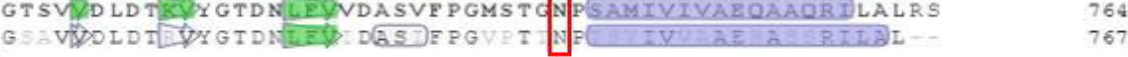

Fonte: Arquivo próprio.

Nota: As setas verdes indicam a estrutura secundária predita de $\beta$-folha, os balóes roxos as estruturas de $\alpha$ hélice e as barras roxas indicam a similaridade. O símbolo $\star$ indica os aminoácidos catalíticos e as caixas indicam os aminoácidos com funções nos subsítios B e C da M77CDH. 


\subsection{Análise filogenética}

A árvore filogenética presente na Figura 13 foi construída utilizando sequências de proteína de CDHs preditas em basidiomicetos e ascomicetos, contidas no estudo de Harreither et al. (2011) e com buscas realizadas na base de dados UniProt.

O resultado é consistente com a literatura, pois na Classe I foram agrupadas as CDHs de basidiomicetos, enquanto as Classes II e III foram agrupadas as CDHs de ascomicetos. A Classe I apresentou CDHs sem módulo de ligação ao substrato (CBM) dos fungos Trametes versicolor, Athelia rolfsii e Phanerochaete chrysosporium. A Classe IIA apresentou CDHs contendo CBM e foi composta por diversos fungos dos gêneros Podospora, Myriococcum, Neurospora, Chaetomium e Thermothelomyces. A Classe IIB foi constituída por CDHs sem CBM e por várias espécies de Aspergillus e de Crassicarpon, Humicola, Thielavia, Neurospora, Colletotrichum e Thermothelomyces. Sequências ainda não caracterizadas de CDHs e provindas de projetos de sequenciamento genômico envolveram espécies de Botrytis, Aspergillus, Sclerotinia, Nectria, Parastagonospora e Pyrenophora e formaram a Classe III.

A M77CDH é uma CDH de originária de um ascomiceto (T. thermophila) e não contém CBM em sua estrutura e, de acordo com a árvore filogenética obtida, foi clusterizada na Classe IIB, corroborando com a literatura. Além disso, a M77CDH mostrou alta similaridade com CDHs dos fungos termofílicos Crassicarpon thermophilum e Humicola insolens. Essas CDHs já foram caracterizadas, e um aspecto bastante interessante em comum entre elas é a atividade máxima do domínio CYT em pHs alcalinos, propriedade que será comentada em mais detalhes posteriormente. $\mathrm{O}$ alinhamento da $\mathrm{M} 77 \mathrm{CDH}$ com as sequências de CDHs mais similares, de acordo com a árvore filogenética (Figura 13), e já caracterizadas está contido na seção Apêndice A (Figura 30). 
Figura 13 - Análise filogenética de 32 sequências de CDHs de vários fungos, incluindo basidiomicetos e ascomicetos.

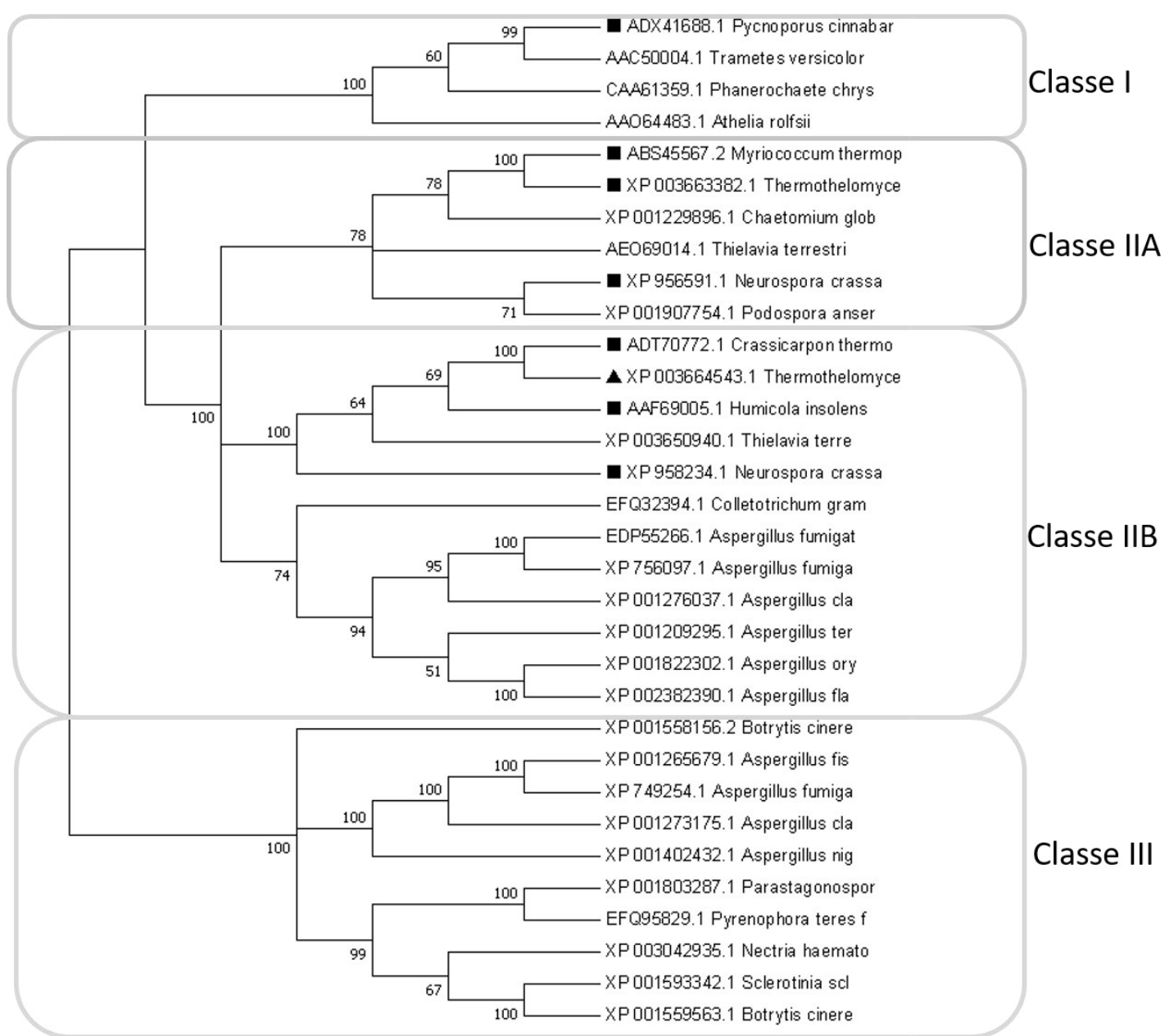

Fonte: Arquivo próprio.

Nota: A Classe I é composta por CDHs de basidiomicetos, a Classe II e III de ascomicetos, em que a Classe IIA são CDHs que contém CBM e Classe IIB sem CBM.

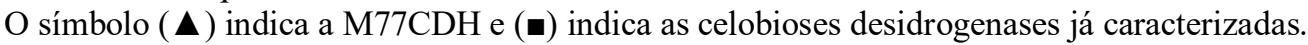

\subsection{Clonagem e expressão da M77CDH e confirmação da proteína por Espectrometria} de Massas (LC-MS/MS)

As etapas de amplificação gênica, clonagem e transformação de protoplastos mediado por PEG foram realizadas pelo grupo de pesquisa do Laboratório de Biologia Sintética e Molecular (SyMB Lab, EEL/USP) e os resultados estão resumidos a seguir. O gene amplificado da $\mathrm{M} 77 \mathrm{CDH}$ de $T$. thermophila apresentou uma banda com a massa molecular similar ao predito por análises de bioinformática de 3092 pb (Figura 14A). O PCR de colônia apresentou uma colônia transformante positiva, ou seja, contendo o plasmídeo composto do vetor pEXPYR associado ao gene de interesse (Figura 14B), a qual foi utilizada para transformar o fungo A. nidulans A773. Por fim, na triagem dos 
transformantes de A. nidulans para expressão da $\mathrm{M} 77 \mathrm{CDH}$ foi observado vários transformantes positivos (Figura 14C).

Figura 14 - Géis referentes às etapas de clonagem e expressão da M77CDH.

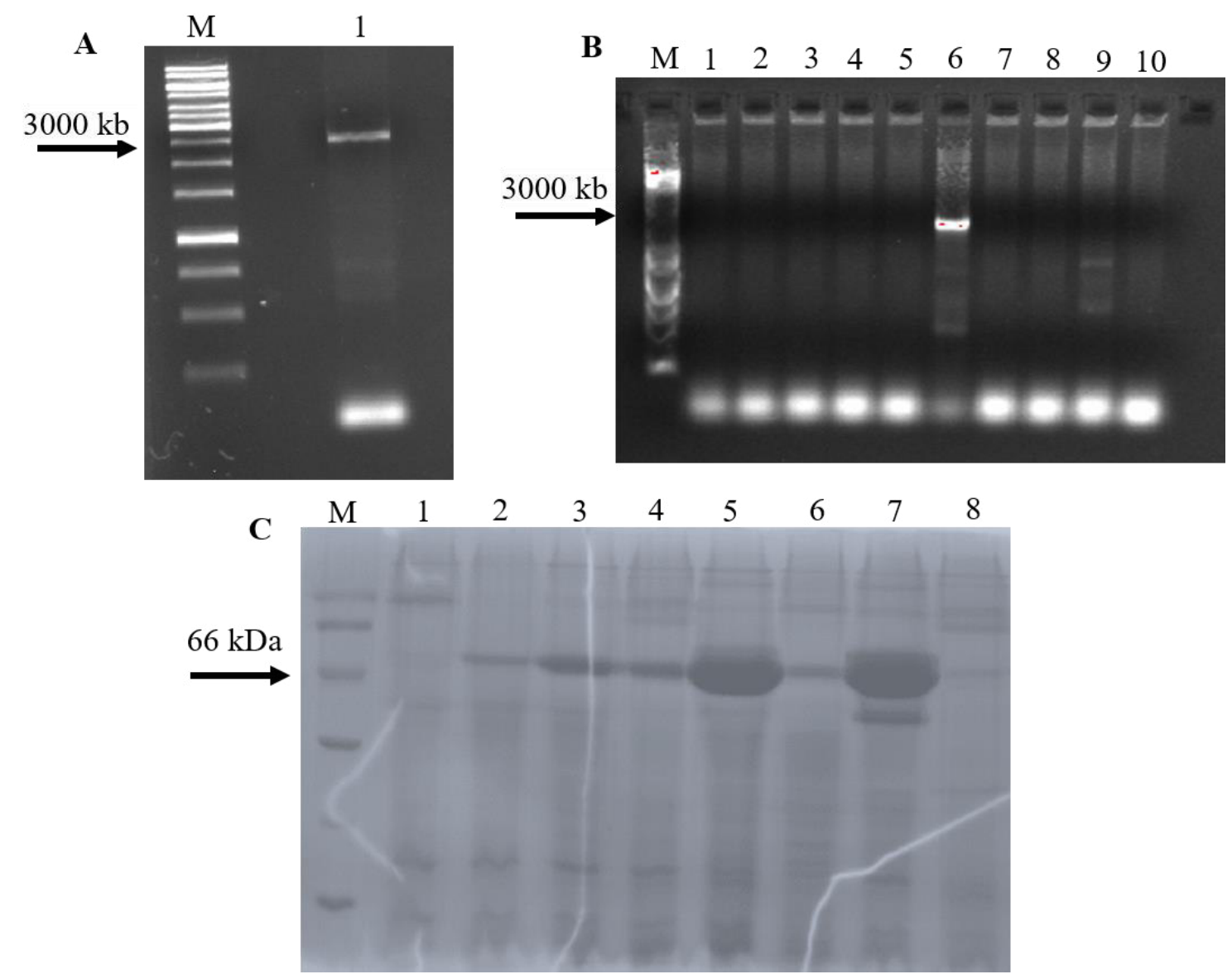

Fonte: Arquivo próprio.

Nota: A: Gene amplificado da M77CDH (linha 1).

B: PCR de colônia das colônias transformantes de bactérias (linhas 1 a 10).

C: Gel de SDS-PAGE $15 \%$ dos transformantes de A. nidulans para a expressão heteróloga da M77CDH (linhas 1 a 8).

M: Marcador.

As setas em A e B indicam a amplificação do gene e em C a banda referente à expressão heteróloga da $\mathrm{M} 77 \mathrm{CDH}$

Para a confirmação da identidade da proteína recombinante expressa em A. nidulans, a banda do gel SDS-PAGE 15\% foi excisada e analisada pela técnica de Espectrometria de Massas acoplada a Cromatografia Líquida (Liquid chromatography tandem-mass spectrometry, em inglês - LC MS/MS) (BALDWIN, 2004). O resultado obtido através da análise com o banco de dados do MASCOT confirmou, com uma cobertura de 47\% (29 peptídeos identificados), que a proteína expressa era de fato a $\mathrm{CDH}$ do fungo filamentoso $T$. thermophila (Figura 15) apresentando uma massa molecular de 84.706 Da (próximo ao predito pela bioinformática de $81.717 \mathrm{Da}$ ). 
Figura 15 - Resultado do espectrômetro de massas da banda excisada do gel referente a M77CDH.

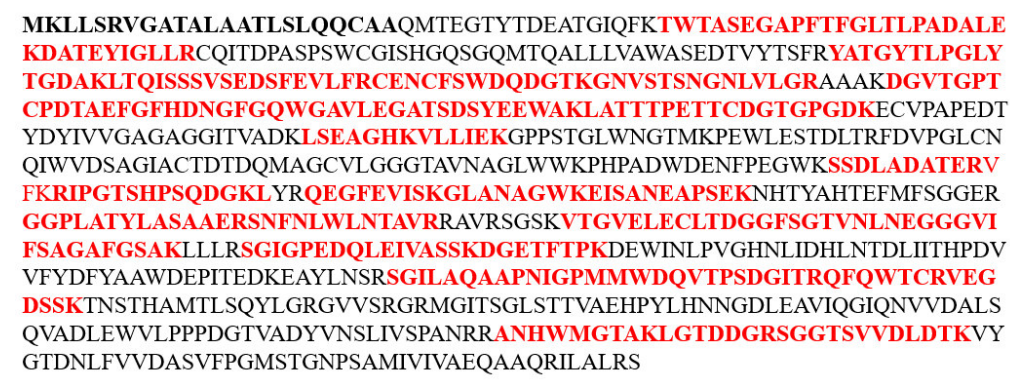

Fonte: Arquivo próprio.

Nota: A cobertura de peptídeos identificados foi de 47\%, confirmando a identidade da enzima de interesse.

As sequências de peptídeos em negrito são referentes ao peptídeo sinal e as destacadas em vermelho são os peptídeos detectados pelo LC-MS/MS.

\subsection{Purificação enzimática}

A purificação enzimática consistiu em etapas de concentração, diálise e em técnicas cromatográficas de troca iônica (DEAE-Sepharose ${ }^{\circledR}$ CL-6B) e exclusão por tamanho (Sephacryl HiPrep ${ }^{\circledR}$ 26/60). A Figura 16A reúne as frações obtidas pela purificação da etapa de troca iônica e o gráfico apresenta a absorção das amostras a $280 \mathrm{~nm}$ (monitorar a quantidade de proteínas) e a $420 \mathrm{~nm}$ (detectar a presença do cofator heme nas frações). As frações 6 e 7 da etapa de troca iônica apresentaram uma banda bastante intensa referente a M77CDH, porém ainda contendo bandas de massa molecular menor. A Figura 16B apresenta o cromatograma referente à etapa de gel filtração, em que as frações de 44 a 50 foram reservadas para as próximas análises de caracterização bioquímica.

O gel de SDS-PAGE das amostras obtidas em cada etapa de purificação é mostrado na Figura 17A. A etapa de gel filtração (linha 3) apresentou uma banda menos intensa, porém com menos impurezas em relação à troca iônica (linha 2) e bastante eficiente em relação ao extrato bruto (linha 1 ).

Como mencionado anteriormente, modificações pós-traducionais como as glicosilações em enzimas CDHs expressas heterólogamente é um fator importante a se considerar ao verificar se o chassi de expressão utilizado é conveniente e se a enzima é de alta qualidade (atividade semelhante a enzima não recombinante). Na M77CDH foram preditos 3 potencias sítios de $N$-glicosilação (NetNGlyc 1.0) e 10 de $O$-glicosilação (NetOGlyc 4.0). A M77CDH foi tratada com PNGase e Endo H (Figura 17B) para retirada de $N$-glicosilações da estrutura da proteína e em ambos tratamentos a proteína apresentou uma leve redução de massa molecular, confirmando similaridade com a massa molecular predita de 81.717 Da. 
Figura 16 - Géis de SDS-PAGE e cromatogramas referentes às etapas de troca iônica e gel filtração de purificação da proteína $\mathrm{M} 77 \mathrm{CDH}$.

A

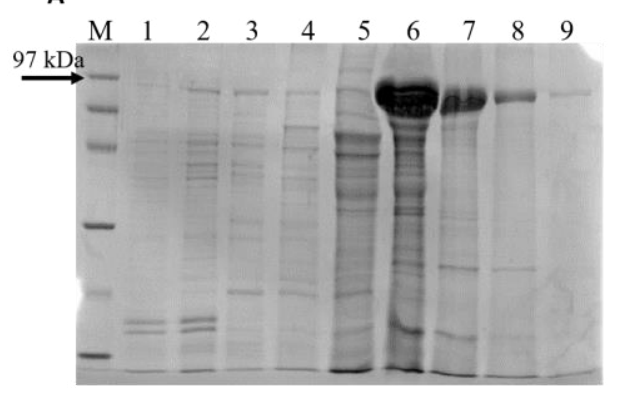

C

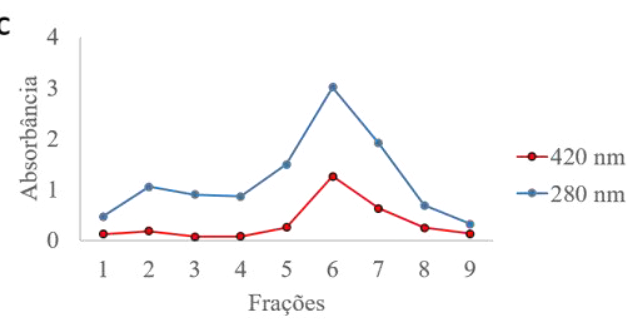

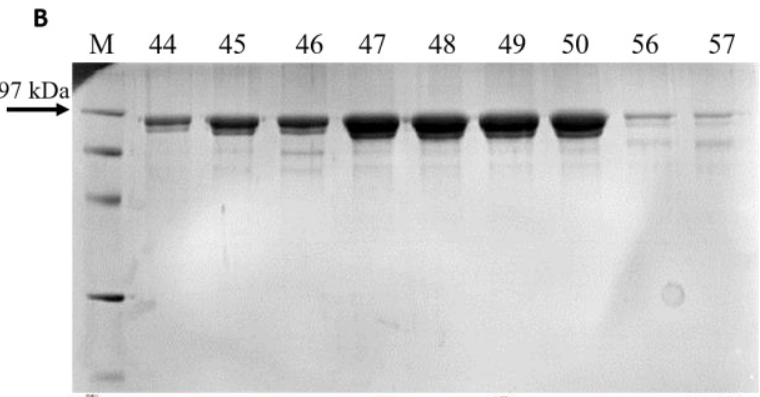

D

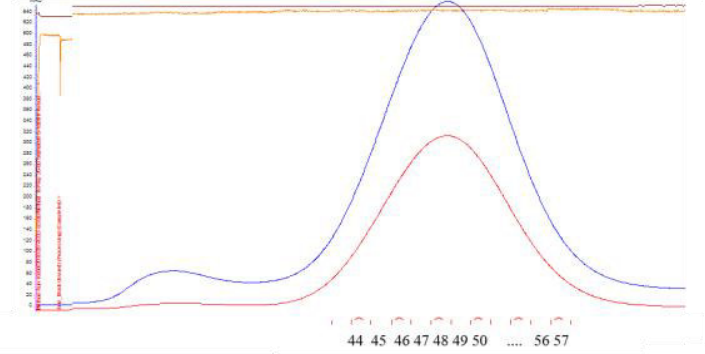

Fonte: Arquivo próprio.

Nota: A: Gel de SDS-PAGE das frações eluídas na etapa de troca iônica, em que M (marcador) 1 (descarte inicial), 2 (lavagem com tampão), 3 (solução $50 \mathrm{mM}$ de NaCl), $4(100 \mathrm{mM} \mathrm{NaCl}), 5(200 \mathrm{mM} \mathrm{NaCl})$, 6 (300 mM NaCl), 7 (400 mM NaCl), 8 (500 mM NaCl) e $9(1 \mathrm{M} \mathrm{NaCl})$.

B: Gel de SDS-PAGE das frações eluídas na exclusão molecular.

C e D: Cromatogramas referentes às etapas de troca iônica e gel filtração com leitura das frações à 280 $\mathrm{nm}$ e $420 \mathrm{~nm}$.

Figura 17 - Géis de SDS-PAGE do teste de desglicosilação.

A

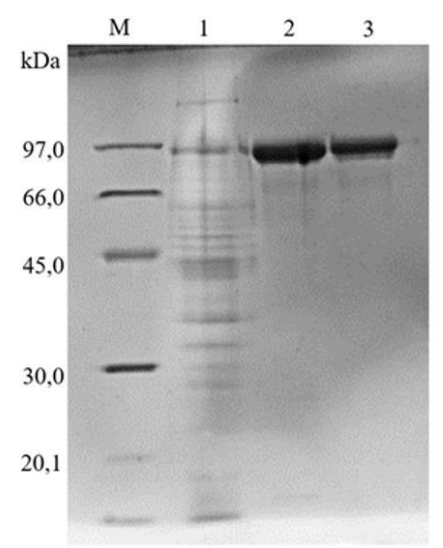

B

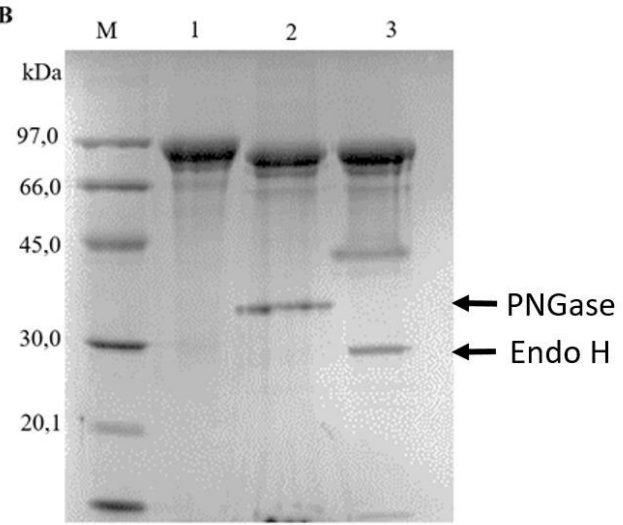

Fonte: Arquivo próprio.

Nota: A: Gel SDS-PAGE contendo $10 \mu \mathrm{g}$ de proteínas presentes no extrato bruto (linha 1) e nas etapas de purificação de troca iônica (linha 2) e exclusão de tamanho (linha 3).

B: M77CDH purificada (linha 1) e tratada com PNGase (linha 2) e Endo H (linha 3). As bandas adicionais em $35 \mathrm{kDa}$ (linha 2) e $29 \mathrm{kDa}$ (linha 3) nas amostras desglicosiladas são devido a presença da PNGase e Endo H, respectivamente.

M: Marcador de proteínas em kDa. 


\subsection{Caracterização espectral da M77CDH}

A caracterização espectral para observar o perfil do espectro UV/Visível é uma técnica comum em hemeflavoproteínas. Essas enzimas contêm ferro e o cofator FAD na sua estrutura que apresentam picos de absorbância característicos. O espectro UV/Visível para a M77CDH purificada foi característico para uma hemeflavoproteína (LUDWIG et al., 2010; MA et al., 2017; TURBE-DOAN et al., 2013), sendo possível, em suas formas oxidada e reduzida, determinar a presença de ambos os cofatores flavina (FAD) e haem $b$. No estado oxidado, o espectro da M77CDH apresentou um "ombro" mais acentuado na absorbância entre 450 e $500 \mathrm{~nm}$, o qual é atribuído ao cofator FAD, já o pico em 420 é característico da banda Soret do cofator haem $b$ (Figura 18). No estado reduzido da M77CDH, a mudança do pico de $420 \mathrm{~nm}$ para $430 \mathrm{~nm}$ e o aparecimento de picos de absorbância em 530 e $560 \mathrm{~nm}$ são devido a banda Soret (referente a maior absorbância na região do visível do complexo de ferro e porfirina) e as picos $\beta$ e $\alpha$ (maior absorção na região do visível do complexo de ferro e porfirina) do cofator haem $b$ reduzido (MARTINS E SILVA, 1970; PHILLIPS, 1963). Em relação ao cofator FAD, a adição de lactose à solução contendo a enzima promove a redução deste cofator, resultando na diminuição da absorbância do FAD entre 450 e 500 nm (BAMINGER et al., 2001; HARREITHER et al., 2009; SULEJ et al., 2015).

Figura 18 - Espectro UV-Visível da forma oxidada e reduzida da M77CDH.

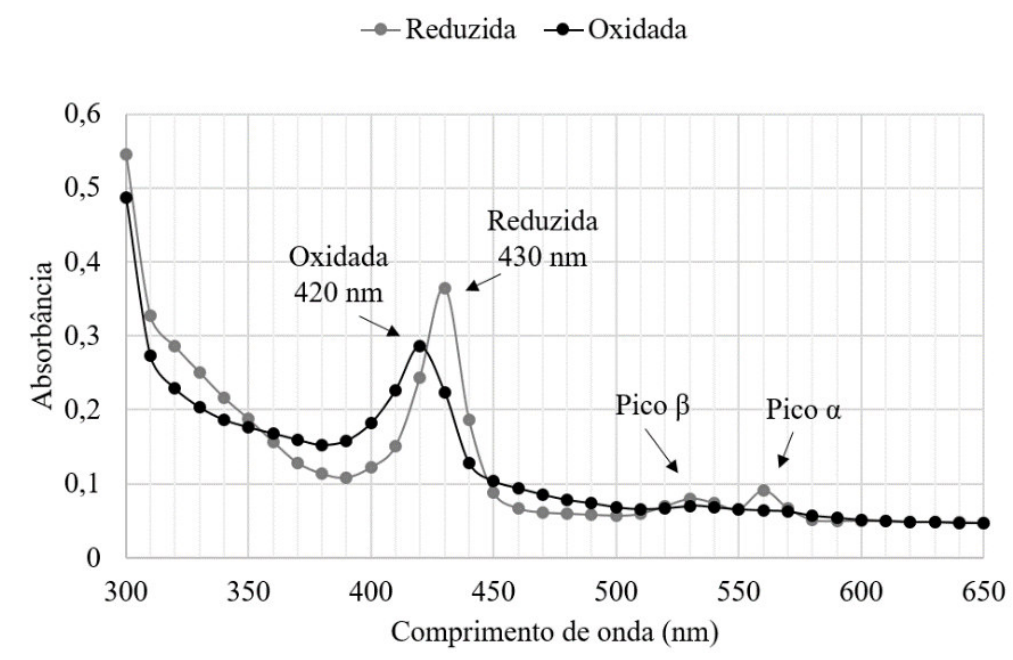

Fonte: Arquivo próprio.

Nota: A M77CDH purificada foi incubada em tampão sódio acetato 100 mM (pH 4,5).

$\mathrm{O}$ estado reduzido foi realizado com adição de excesso molar de lactose. 


\subsection{Caracterização bioquímica da M77CDH}

As duas CDHs nativas de T. thermophila já foram purificadas anteriormente, porém o estudo não apresentou dados de $\mathrm{pH}$ e temperatura ótimos e estabilidade das enzimas (CANEVASCINI; BORER; DREYER, 1991). Um outro estudo de uma CDH de $T$. thermophila M77 detalhou um pouco mais em características catalíticas e moleculares, e revelou que a enzima do estudo possuía CBM e alta termoestabilidade (SUBRAMANIAM; NAGALLA; RENGANATHAN, 1999). Logo, este estudo traz a caracterização bioquímica mais detalhada da $\mathrm{CDH}$ de $T$. thermophila sem presença de $\mathrm{CBM}$, produzida e expressa de maneira heteróloga no fungo filamentoso $A$. nidulans.

Apesar de não se saber ao certo o aceptor natural de elétrons das CDHs, o aceptor de elétrons citocromo $c$ de mamíferos (de coração de bovinos ou de cavalo) é uma excelente molécula para avaliar a atividade da enzima na sua forma intacta (contendo domínio DH e CYT). Por outro lado, a atividade da CDH utilizando DCIP é importante para verificar o desempenho somente do domínio DH (LUDWIG et al., 2010). Portanto, os experimentos de pH e temperatura ótimos foram realizados com ambos aceptores de elétrons.

\subsection{1 pH ótimo e estabilidade ao pH}

A Figura 19A apresenta o perfil da influência da variação do $\mathrm{pH}$ na atividade enzimática da M77CDH purificada. Os valores de $\mathrm{pH}$ ótimo para DCIP e cyt c como aceptores de elétrons foram entre $\mathrm{pH}$ 5,5-6,0 e $\mathrm{pH}$ 7,0-9,0, respectivamente. A M77CDH apresentou uma ampla faixa de atuação nos pHs testados, em que mais de $80 \%$ da sua atividade residual foi entre $\mathrm{pH} 4,5-8,0$ (DCIP) e 6,0-9,0 (cyt c) (Figura 19A). Diferentemente de CDHs de outros fungos, como Coprinopsis cinerea e Podospora anserina, que apresentaram atividade acima de 80\% (utilizando DCIP) apenas numa estreita faixa de pH 5,0-6,0 (TURBE-DOAN et al., 2013). A atividade da M77CDH manteve-se abaixo de $20 \%$ somente em valores de $\mathrm{pH}$ extremamente ácido (pHs 2,0-3,0) ou básico (pH 10,0-11,0), para ambos aceptores de elétrons.

Ainda em relação a faixa de $\mathrm{pH}$, foi reportado uma $\mathrm{CDH}$ de Phanerochaete chrysosporium que apresentou $\mathrm{pH}$ ótimo em faixa mais ácida (3,5-4,0 para DCIP) e uma de Humicola insolens em faixa mais alcalina (6,5-7,0 para DCIP e 7,5-8,0 para cyt c) (IGARASHI et al., 1999; SCHOU; CHRISTENSEN; SCHULEIN, 1998). É característico para as espécies de CDHs da Classe II que tenham uma maior variedade de faixas ótimas de $\mathrm{pH}$ (separadas em grupos ácido, intermediário e alcalino), enquanto que CDHs da Classe I 
tem atuação somente em pHs mais ácidos (pH 3,5 a 4,5) (HARREITHER et al., 2011; LUDWIG et al., 2010).

Figura 19 - Influência do pH na atividade e na estabilidade da M77CDH.
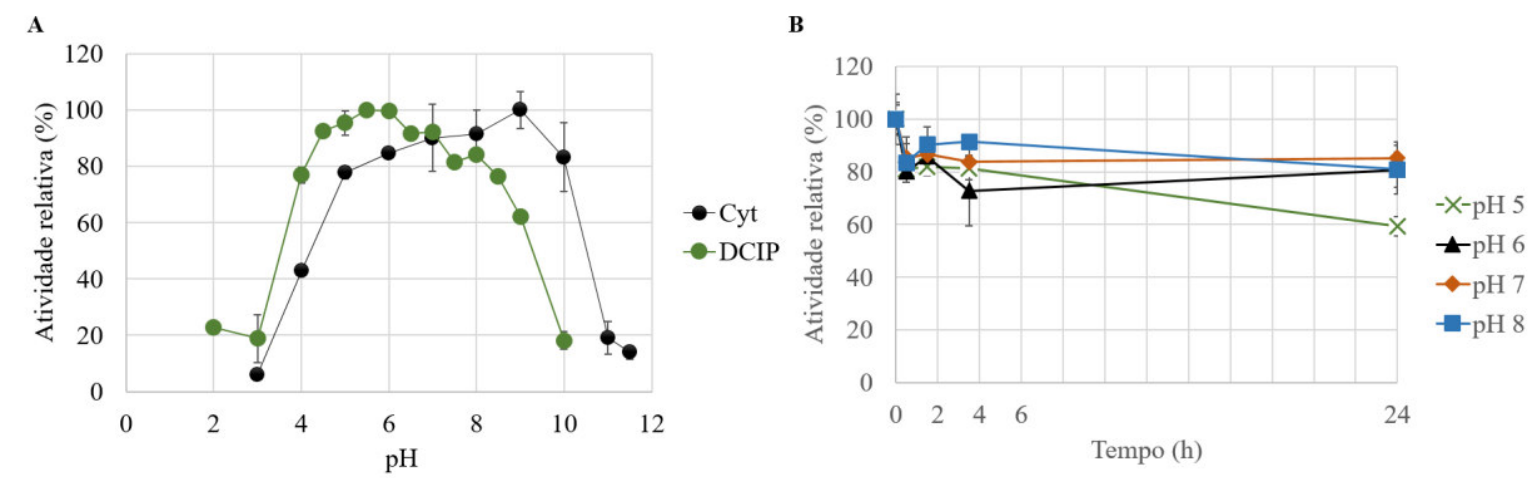

Fonte: Arquivo próprio.

Nota: A: Influência do pH na atividade enzimática da M77CDH utilizando citocromo c (preto) e DCIP (cinza) como aceptores de elétron. A atividade máxima (100\%) foi definida pela atividade em pH 5,5.

B: Estabilidade da M77CDH em diferentes pH $\left(5,6,7\right.$ e 8,0) com incubação durante 90 min $\left(30^{\circ} \mathrm{C}\right)$, utilizando DCIP como aceptor de elétrons.

Os valores das médias são referentes a duplicatas. Quando não presente as barras de erro, indica que os desvios padrões não excederam $5 \%$.

Em um estudo com a $\mathrm{CDH}$ do fungo termofílico Thielavia terrestris, a enzima TtCDH apresentou um pH ótimo entre 5 e 6 (DCIP), porém a partir de 7,0 sua atividade diminuiu drasticamente para cerca de $50 \%$ e atingiu menos de $20 \%$ em $\mathrm{pH} 8,0-9,0$. Isso mostra um perfil diferente da $\mathrm{M} 77 \mathrm{CDH}$, em que apresentou atividade significativa em $\mathrm{pHs}$ mais alcalinos, pois manteve mais de $60 \%$ da sua atividade (DCIP e cyt c) em pH 9,0 (LANGSTON et al., 2012).

Os resultados da Figura 19A demonstram que o domínio DH apresenta uma maior eficiência em pH ligeiramente ácido, enquanto o domínio CYT possui maior afinidade por $\mathrm{pH}$ alcalino. Como visto na árvore filogenética (Figura 13), a $\mathrm{M} 77 \mathrm{CDH}$ apresentou semelhança com as CDHs de Crassicarpon thermophium (CtCDH) e H. insolens (CBDH). De fato, essas proteínas já são caracterizadas e apresentaram atividades máximas do domínio CYT (utilizando citocromo $c$ como aceptor de elétrons) em pHs levemente alcalinos. No caso da $C t \mathrm{CDH}$, apresentou atividade máxima em $\mathrm{pH}$ 7,5 e a $\mathrm{CBDH}$ em $\mathrm{pH}$ 8-9, muito semelhantes ao pH ótimo do domínio CYT para a M77CDH (pH 8,0-9,0) (HARREITHER et al., 2011; SCHOU; CHRISTENSEN; SCHULEIN, 1998). Essa pode ser uma propriedade vantajosa, já que a característica de atuar em pH alcalino não é comum entre as CDHs já descritas na literatura (HENRIKSSON; PETTERSSEN; JOHANSSON, 2000). Além disso, quando cyt c é utilizado para determinar o pH ótimo da $\mathrm{CDH}$, analisa-se a condição ótima 
para a transferência intramolecular de elétrons (do FAD para o cyt c) (HARREITHER et al., 2011) e a M77CDH apresentou um ótimo desempenho em $\mathrm{pH}$ alcalino.

Em relação à estabilidade ao $\mathrm{pH}$, a $\mathrm{M} 77 \mathrm{CDH}$ mostrou ser pouco afetada pelos diferentes pH (entre 5,0 e 8,0) ao longo do tempo (Figura 19B), mantendo-se estável por 24 horas em pH levemente alcalinos (pH 6 a 8). Em estudo de Turbe-Doan et al. (2013), as CDHs de $C$. cinerea e $P$. anserina apresentaram estabilidade em valores de $\mathrm{pH}$ na faixa entre 4,0-8,0 durante 24 h, sendo também levemente mais estáveis nos $\mathrm{pH}$ mais básicos ( $\mathrm{pH} 7$ e $8)$.

\subsubsection{Temperatura ótima e estabilidade térmica}

A grande vantagem na utilização de sistemas de expressão heteróloga é possibilitar o estudo de proteínas que não são secretadas abundantemente pelos organismos de origem. O objetivo deste trabalho é estudar a enzima $\mathrm{CDH}$ recombinante do fungo termofílico $T$. thermophila, visando caracterizar enzimas com potencial de estabilidade a altas temperaturas. De fato, a temperatura ótima determinada para a $\mathrm{M} 77 \mathrm{CDH}$ foi de $65{ }^{\circ} \mathrm{C}$ (DCIP) e entre $50-60{ }^{\circ} \mathrm{C}(c y t$ c) (Figura 20A). A enzima manteve uma atividade relativa acima de $80 \%$ entre temperaturas de 50 a $75^{\circ} \mathrm{C}$, e somente a $85^{\circ} \mathrm{C}$ ocorreu uma diminuição drástica da atividade enzimática para abaixo de 40\%. Em um estudo com a CDH do fungo termofílico $H$. insolens, a enzima apresentou atividade máxima a $65^{\circ} \mathrm{C}$, porém sua ação foi completamente inibida quando incubada a temperatura de $70^{\circ} \mathrm{C}$ (SCHOU; CHRISTENSEN; SCHULEIN, 1998), já a M77CDH reteve mais de 95\% da sua atividade nesta mesma temperatura.

A enzima $\mathrm{M} 77 \mathrm{CDH}$ demonstrou uma estabilidade térmica satisfatória em temperaturas entre 50 e $55{ }^{\circ} \mathrm{C}$ durante 5 horas de incubação, retendo mais de $50 \%$ da sua atividade a $55^{\circ} \mathrm{C}$ (Figura 20B). Em temperaturas próximas a sua ótima (60 e $65^{\circ} \mathrm{C}$ ) a estabilidade térmica foi bastante afetada, apresentando apenas $26 \%$ de sua atividade residual após 5 horas de incubação a $65{ }^{\circ} \mathrm{C}$. Estes dados foram similares ao apresentado em estudos com a CDH dos fungos termofílicos Myriococcum thermophilum (ZÁMOCKY et al., 2008) e de Thielavia terrestris (LANGSTON et al., 2012), pois a $65^{\circ} \mathrm{C}$ foi a atividade máxima de ambas CDHs e em Zámocky et al. (2008) a termoestabilidade foi bastante afetada em algumas horas de incubação a $65^{\circ} \mathrm{C}$. A fim de comparação, CDHs dos fungos mesofílicos C. cinerea e $P$. anserina apresentaram temperaturas ótimas de $60{ }^{\circ} \mathrm{C}$ e $65-70{ }^{\circ} \mathrm{C}$, respectivamente. Entretanto, apresentaram estabilidade térmica significativa (> 50\%) somente a $40{ }^{\circ} \mathrm{C}$ por 4 horas (TURBE-DOAN et al., 2013). Isso indica que a M77CDH, 
proveniente de um fungo termofílico, apresenta propriedades superiores em temperaturas elevadas, devido a sua estabilidade na faixa de $50-55{ }^{\circ} \mathrm{C}$.

Figura 20 - Influência da temperatura na atividade e na estabilidade da M77CDH.
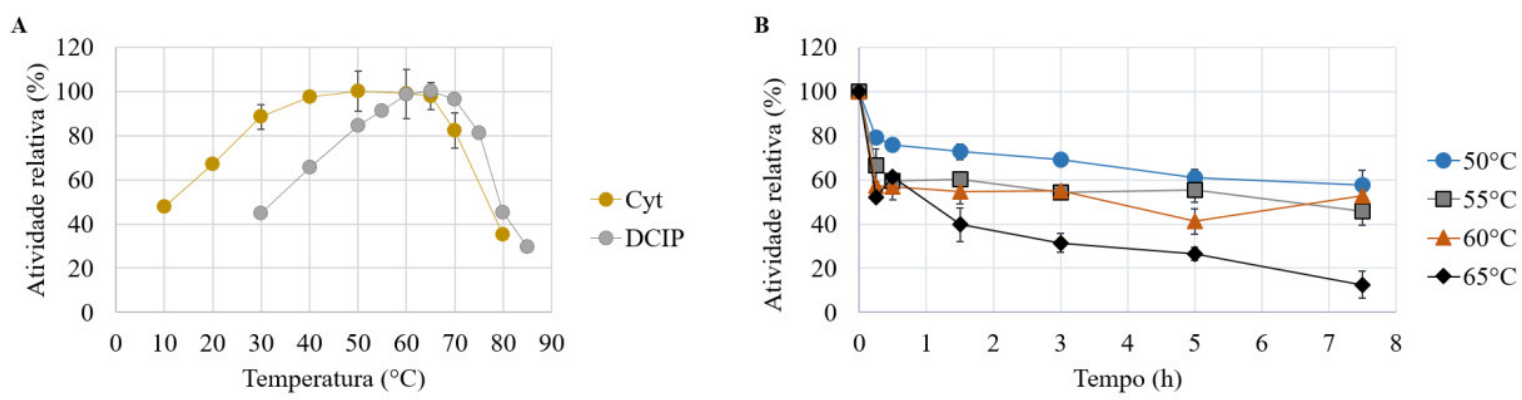

Fonte: Arquivo próprio.

Nota: A: Perfil de atividade da M77CDH de acordo com a variação de temperatura, utilizando cyt c (preto) e DCIP (cinza) como aceptores de elétrons.

B: Estabilidade térmica da $\mathrm{M} 77 \mathrm{CDH}$ em diferentes temperaturas e tempos de incubação utilizando DCIP como aceptor de elétrons.

Os valores das médias são referentes a duplicatas. Quando não presente as barras de erro, indica que os desvios padrões não excederam $5 \%$.

\subsection{Dicroísmo Circular (CD)}

O CD é um método de espectroscopia importante para a biologia estrutural, em que possibilita analisar as estruturas de proteínas, polipeptídeos e peptídeos. Além disso, é capaz de estimar a estabilidade da estrutura enovelada da proteína ao longo do aumento da temperatura ou em solução com agentes desnaturantes. Em geral quando se analisa proteínas por CD, os cromóforos de interesse são as ligações peptídicas (absorção abaixo de $240 \mathrm{~nm}$ ), aminoácidos aromáticos (absorção entre 260 e 320 nm), ligações dissulfeto (baixa absorção próximo a $260 \mathrm{~nm}$ ) e cofatores não-proteicos, como flavinas (absorvem na região entre 300 e $500 \mathrm{~nm}$ ) e grupos haem (absorvem fortemente a 410 e entre 350 a $500 \mathrm{~nm}$, dependendo do estado e coordenação do íon de ferro) (KELLY; JESS; PRICE, 2005).

Nos ensaios de dicroísmo circular com a M77CDH foi utilizado a região do UV distante (abaixo de $260 \mathrm{~nm}$ ) e, de acordo com a literatura, o perfil do espectro encontrado é semelhante ao apontado para estruturas com $\beta$-folha, devido ao pico negativo na região de $218 \mathrm{~nm}$ na estrutura enovelada (Figura 21A). Não foi possível obter o espectro abaixo de $200 \mathrm{~nm}$, devido a relação sinal-ruído ter sido muito alta.

Observou-se ainda na Figura 21A que o perfil de elipticidade da M77CDH em temperaturas acima de $65^{\circ} \mathrm{C}$ foi alterado. Esse fenômeno é melhor ilustrado na Figura 21B, em que a queda na detecção de sinal do CD pelo aumento da temperatura permite estimar a estabilidade da estrutura enovelada da proteína (KELLY; JESS; PRICE, 2005). Na Figura 
21B, observa-se que a temperatura de transição (ou de desenovelamento, $T_{m}$ ) para a M77CDH foi de $62,8 \pm 0,5{ }^{\circ} \mathrm{C}$, em que $50 \%$ da proteína em solução apresenta-se em sua forma desenovelada (VIEILLE; ZEIKUS, 2001). Esse parâmetro indica a propriedade de uma proteína termoestável, já que possui estabilidade de sua estrutura enovelada em temperaturas elevadas, para uma enzima de origem fúngica. Para a $\mathrm{Ct} \mathrm{CDH}$ de Crassicarpon thermophium foi encontrada uma $\mathrm{T}_{\mathrm{m}}$ de $58,1 \pm 1,5^{\circ} \mathrm{C}$, e apesar da $C t \mathrm{CDH}$ de ser bastante semelhante filogeneticamente à $\mathrm{M} 77 \mathrm{CDH}$, apresenta uma menor termoestabilidade (MA et al., 2017).

Figura 21 - Dicroísmo circular e espectro da desnaturação térmica da M77CDH.

$\mathbf{A}$

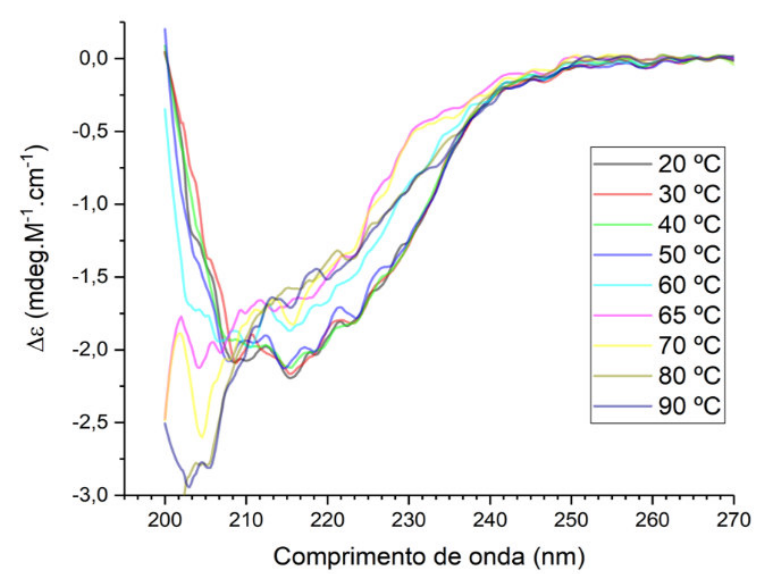

B

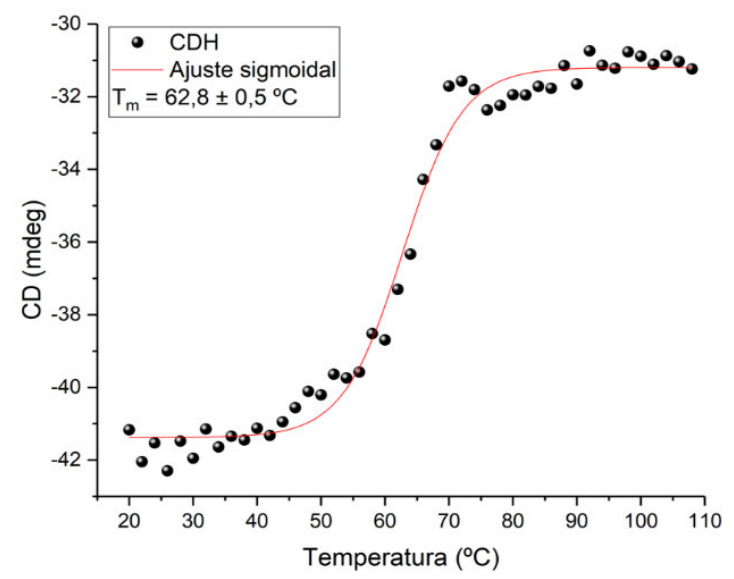

Fonte: Arquivo próprio.

Nota: A: Espectro de desnaturação térmica em elipticidade da M77CDH.

B: Curva de transição de temperatura da M77CDH analisada por dicroísmo circular.

\subsection{Influência de íons e compostos químicos na atividade da M77CDH}

Prosseguindo com a caracterização bioquímica, avaliou-se a influência de alguns íons e compostos químicos na atividade enzimática da $\mathrm{M} 77 \mathrm{CDH}$, em que se analisou um total de 17 compostos. Os resultados obtidos mostraram que vários íons metálicos proporcionaram um aumento na atividade da M77CDH (Tabela 3), destacando-se, principalmente, os íons $\mathrm{Mg}^{2+}$ e o $\mathrm{MoO}_{4}{ }^{2-}$. Para a $\mathrm{M} 77 \mathrm{CDH}$, na presença de $15 \mathrm{mM}$ de $\mathrm{Mg}^{2+}$

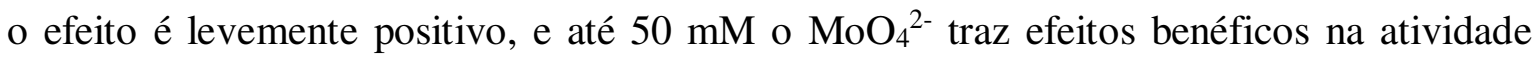
(Figura 22). Para as CDHs já caracterizadas de outros trabalhos, não se observou, nem de modo positivo nem negativo, o efeito do íon $\mathrm{Mg}^{2+}$ na atividade (SULEJ et al., 2013a, 2015). Além disso, ainda não foi reportado o efeito do composto $\mathrm{MoO}_{4}{ }^{2-}$ na atividade de nenhuma $\mathrm{CDH}$ caracterizada. 
Tabela 3 - Efeito de vários íons e solventes na atividade enzimática da M77CDH.

\begin{tabular}{lc}
\hline $\begin{array}{l}\text { Ions metálicos/ } \\
\text { Compostos químicos }\end{array}$ & $\begin{array}{c}\text { Atividade } \\
\text { relativa (\%) }\end{array}$ \\
\hline Controle & 100 \\
$\mathrm{Ca}^{2+}$ & $102,7 \pm 6,3$ \\
$\mathrm{MoO}_{4}^{2-}$ & $110,3 \pm 0,3$ \\
$\mathrm{Mn}^{2-}$ & $90,5 \pm 11,2$ \\
$\mathrm{Zn}^{2+}$ & $100,9 \pm 5,3$ \\
$\mathrm{Mg}^{2+}$ & $112,9 \pm 5,4$ \\
$\mathrm{Cl}^{-}$ & $109,6 \pm 2,3$ \\
$\mathrm{H}_{2} \mathrm{PO}_{4}{ }^{-}$ & $107,0 \pm 6,9$ \\
$\mathrm{NH}_{4}^{+}$ & $95,6 \pm 5,1$ \\
$\mathrm{SO}_{4}^{2-}$ & $96,5 \pm 1,8$ \\
$\mathrm{Na}^{+}$ & $94,9 \pm 4,0$ \\
$\mathrm{Cu}^{2+}$ & 0 \\
$\mathrm{Co}^{2+}$ & $85,3 \pm 6,9$ \\
$\mathrm{Fe}^{3+}$ & $32,8 \pm 2,0$ \\
$\mathrm{SDS}^{2+}$ & $103,2 \pm 0,7$ \\
$\mathrm{Etanol}$ & $104,3 \pm 5,8$ \\
EDTA & $106,0 \pm 6,1$ \\
\hline &
\end{tabular}

Fonte: Arquivo próprio.

Nota: A atividade enzimática sem a adição de metal ou inibidor foi considerada como controle (100\%).

A concentração final do sal foi de $10 \mathrm{mM}$.

Os ensaios foram realizados com DCIP.

Os valores das médias são referentes a duplicatas.

Por outro lado, alguns íons tiveram efeito negativo, em que o $\mathrm{Cu}^{2+} \mathrm{e} \mathrm{Fe}^{3+}$ foram os mais prejudiciais (Tabela 3). Ambos compostos $\mathrm{CuSO}_{4}$ e $\mathrm{FeCl}_{3}$ iniciaram seu efeito na atividade da M77CDH a partir da concentração de $2 \mathrm{mM}$ (Figura 23).

$\mathrm{Na} \mathrm{CDH}$ de Cerrena unicolor o efeito deletério do $\mathrm{CuSO}_{4}$ não foi tão expressivo como no presente estudo, porém a CDH de Volvariella volvacea apresentou uma grande inibição pelo íon $\mathrm{Cu}^{2+}$, mantendo apenas $12 \%$ de sua atividade relativa na presença de $5 \mathrm{mM}$ de $\mathrm{Cu}^{2+}$ (CHEN et al., 2017; SULEJ et al., 2015). Por outro lado, nenhum trabalho reportou o efeito do $\mathrm{FeCl}_{3}$ na atividade de CDHs. 
Figura 22 - Efeito dos compostos $\mathrm{MgCl}_{2}$ e $\mathrm{Na}_{2} \mathrm{MoO}_{4}$ em diferentes concentrações na atividade enzimática da $\mathrm{M} 77 \mathrm{CDH}$.

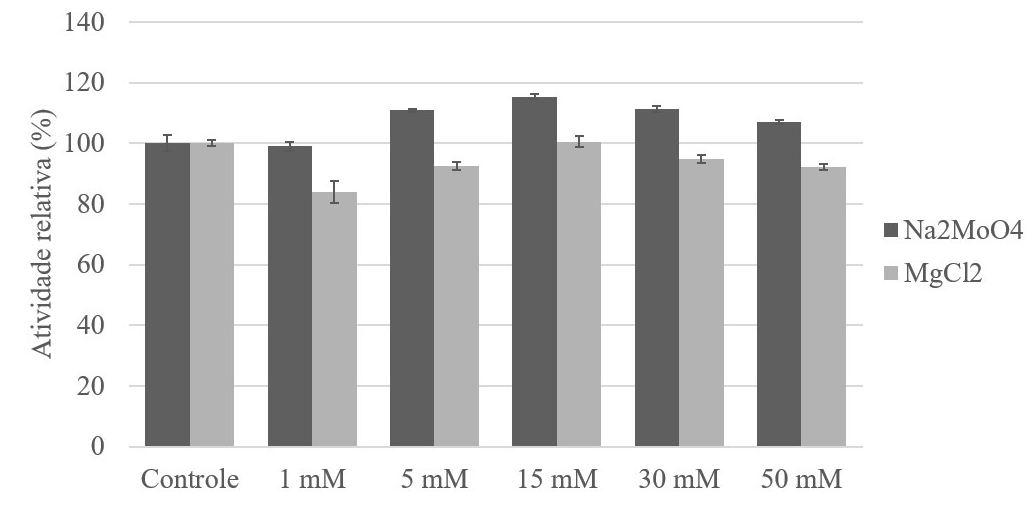

Fonte: Arquivo próprio.

Nota: A atividade enzimática sem a adição de metal foi considerada como controle (100\%).

Os ensaios foram realizados com DCIP.

Os valores das médias são referentes a duplicatas.

Figura 23 -Efeito dos compostos $\mathrm{CuSO}_{4}$ e $\mathrm{FeCl}_{3}$ em diferentes concentrações na atividade enzimática da $\mathrm{M} 77 \mathrm{CDH}$.

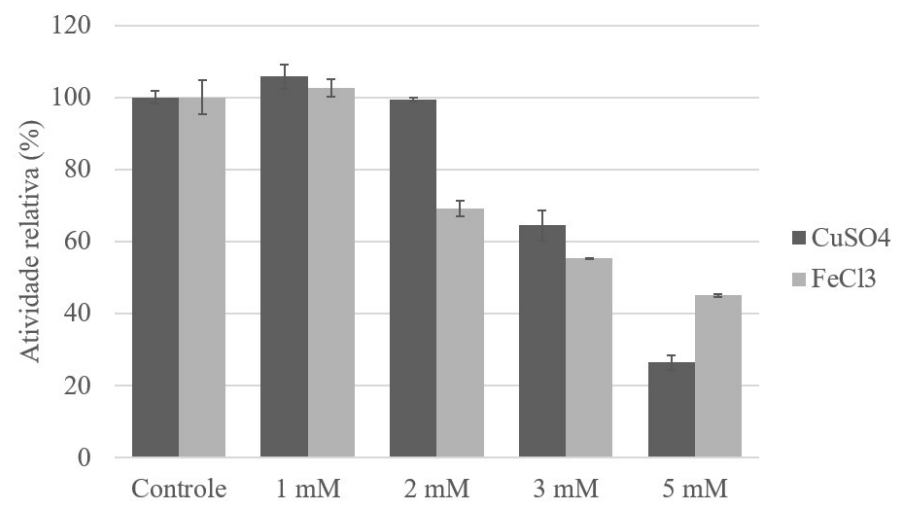

Fonte: Arquivo próprio.

Nota: A atividade enzimática sem a adição de metal foi considerada como controle (100\%).

Os ensaios foram realizados com DCIP.

Os valores das médias são referentes a duplicatas.

Uma hipótese levantada durante o trabalho foi de que a enzima M77CDH estivesse doando os elétrons para os metais $\mathrm{Cu}$ e Fe, ao invés de doá-los para o aceptor DCIP e, desfavorecendo, assim, a detecção da atividade enzimática. Logo, essa hipótese indica a maior afinidade da enzima pelos metais em relação ao DCIP. Essa hipótese está baseada nas propriedades da $\mathrm{CDH}$ já descritas na literatura, em que é capaz de promover a redução do átomo de cobre das LPMOs (favorecendo a ativação da LPMO) e a redução de íons de ferro durante a sacarificação da biomassa (favorecendo a reação de Fenton) (GRINHUT et al., 2011; LUDWIG et al., 2010; PHILLIPS et al., 2011). Porém, estudos mais específicos 
determinando a direção do fluxo de elétrons seriam necessários para avaliar a hipótese. Em relação aos compostos químicos SDS, etanol e EDTA, não foi observado efeito significativo na atividade de $\mathrm{M} 77 \mathrm{CDH}$.

\subsection{Determinação dos parâmetros cinéticos}

Os parâmetros cinéticos da M77CDH foram determinados utilizando celobiose como substrato e observou-se um comportamento Michaeliano na curva da cinética enzimática (Apêndice B - Figura 31) (MICHAELIS; MENTEN, 1913). O valor de $\mathrm{k}_{\mathrm{m}}(65,83 \mu \mathrm{M}$, em DCIP) (Tabela 4) está dentro da faixa reportada para a maioria das CDHs, que se encontra entre 50 a $200 \mu \mathrm{M}$, assim como o valor de $\mathrm{k}_{\text {cat }}\left(17,56 \mathrm{~s}^{-1}\right)$ reportado entre 10 e $30 \mathrm{~s}^{-1}$ (HARREITHER et al., 2011).

Em relação ao valor de eficiência catalítica, a M77CDH $\left(\mathrm{k}_{\mathrm{cat}} / \mathrm{k}_{\mathrm{m}}=266 \mathrm{mM}^{-1} \mathrm{~s}^{-1}\right.$, em DCIP) apresentou valores bastante superiores às apresentadas para as CDHs dos fungos $V$. volvacea $\left(17,242 \mathrm{mM}^{-1} \mathrm{~s}^{-1}\right)$, Cerrena unicolor $\left(66,18 \mathrm{mM}^{-1} \mathrm{~s}^{-1}\right)$ e Podospora anserina (64 $\left.\mathrm{mM}^{-1} \mathrm{~s}^{-1}\right)$. No entanto, quando comparada à $\mathrm{CDH}$ do fungo termofílico Thielavia terrestris $\left(320 \mathrm{mM}^{-1} \mathrm{~s}^{-1}\right)$ e do basidiomiceto Coprinopsis cinerea $\left(621 \mathrm{mM}^{-1} \mathrm{~s}^{-1}\right)$, a eficiência catalítica da M77CDH foi menor (CHEN et al., 2017; HARREITHER et al., 2011; LANGSTON et al., 2012; SULEJ et al., 2015; TURBE-DOAN et al., 2013). Os valores de $\mathrm{k}_{\mathrm{cat}} / \mathrm{k}_{\mathrm{m}}$ referentes a cinética realizada com cyt c (Tabela 4) também estão de acordo com os parâmetros de outras CDHs, como de C. unicolor $\left(109 \mathrm{mM}^{-1} \mathrm{~s}^{-1}\right)$ e de Crassicarpon thermophilum (CtCDH) $\left(250 \mathrm{mM}^{-1} \mathrm{~s}^{-1}\right)$ (HARREITHER et al., 2012; SULEJ et al., 2015).

Tabela 4 - Parâmetros cinéticos aparentes para DCIP e cyt c como aceptores de elétrons.

\begin{tabular}{lccc}
\hline & DCIP & \multicolumn{2}{c}{ Cyt c } \\
\cline { 2 - 4 } & $\mathrm{pH} \mathrm{5,5}$ & $\mathrm{pH} \mathrm{4,5}$ & $\mathrm{pH} \mathrm{7,5}$ \\
\cline { 2 - 4 } $\mathrm{k}_{\mathrm{m}}(\mathrm{mM})=$ & 0,06583 & 0,0134 & 0,0057 \\
$\mathrm{k}_{\text {cat }}\left(\mathrm{s}^{-1}\right)=$ & 17,56 & 5,24 & 4,85 \\
$\mathrm{k}_{\mathrm{cat}} / \mathrm{k}_{\mathrm{m}}\left(\mathrm{mM}^{-1} \cdot \mathrm{s}^{-1}\right)=$ & 266,74 & 391,74 & 851,77 \\
\hline
\end{tabular}

Fonte: Arquivo próprio.

Na Tabela 5, estão presentes as constantes cinéticas para o substrato celobiose para CDHs pertencentes às Classes IIA e IIB, segundo o estudo de HARREITHER et al. (2011). Considerando os valores apresentados, observou-se que a eficiência catalítica da M77CDH $\left(\mathrm{k}_{\mathrm{cat}} / \mathrm{k}_{\mathrm{m}}=2,66.10^{5} \mathrm{M}^{-1} \mathrm{~s}^{-1}\right)$ foi superior às $\mathrm{CDHs}$ da Classe IIB $(C t \mathrm{CDH}$ e $H h \mathrm{CDH})$ e muito similares aos da Classe IIA ( $\mathrm{CaCDH}$ e $\mathrm{D} s \mathrm{CDH})$ em relação ao substrato celobiose. Portanto, 
a M77CDH apresenta potencial entre CDHs da Classe IIB na oxidação da celobiose, devido a sua maior eficiência catalítica.

Em geral, já foi reportado que a celobiose é o melhor substrato para as CDHs, seguido de lactose e em menores proporções glicose e maltose, sendo estes últimos denominados "substratos pobres". Também, ao comparar os parâmetros $\mathrm{k}_{\mathrm{m}}$ e eficiência catalítica entre celobiose, lactose, maltose e glicose, e observaram que os valores de $\mathrm{k}_{\mathrm{m}}$ aumentam drasticamente e as eficiências catalíticas diminuem em relação a esses substratos (HARREITHER et al., 2011).

Tabela 5 - Constantes cinéticas aparentes para carboidratos, como doadores de elétrons, envolvendo CDHs de vários ascomicetos.

\begin{tabular}{llc}
\hline & $\mathrm{k}_{\mathrm{cat}} / \mathrm{k}_{\mathrm{m}}\left(\mathrm{M}^{-1} \mathrm{~s}^{-1}\right)$ & $\mathrm{pH}$ do ensaio \\
\cline { 2 - 3 } CtCDH IIB & $0,93 \cdot 10^{5}$ & 5,0 \\
$H h C D H$ IIB & $1,36.10^{5}$ & 5,0 \\
CaCDH IIA & $2,79.10^{5}$ & 6,0 \\
DsCDH IIA & $2,22.10^{5}$ & 5,0 \\
\hline
\end{tabular}

Fonte: Adaptado de (HARREITHER et al., 2011).

Nota: O aceptor de elétrons utilizado foi o DCIP.

CaCDH: CDH de Chaetomium atrobrunneum.

CtCDH: Crassicarpon thermophilum.

DsCDH: Dichomera saubinetii.

HhCDH: Hypoxylon haematostroma.

\subsection{Reação com celobiose e celooligossacarídeos}

A liberação de ácido celobiônico a partir de celobiose pela M77CDH foi analisada ao longo do tempo de reação em duas concentrações da enzima (0,5 e 2,0 $\mu \mathrm{M})$ (Figura 24). Na concentração de $0,5 \mu \mathrm{M}$ de M77CDH (Figura 24A) a conversão de celobiose em ácido celobiônico ocorreu mais lentamente em relação à concentração de 2,0 $\mu \mathrm{M}$ da enzima (Figura 24B). A conversão máxima de celobiose em ácido celobiônico com $2,0 \mu \mathrm{M}$ de M77CDH foi obtida em $240 \mathrm{~min}$, enquanto que com 0,5 $\mu \mathrm{M}$ de $\mathrm{M} 77 \mathrm{CDH}$ a conversão máxima só foi atingida em 20 h. Utilizando-se uma concentração inicial de cerca de $0,7 \mathrm{~g} / \mathrm{L}$ de celobiose foi possível obter $0,4 \mathrm{~g} / \mathrm{l}$ de ácido celobiônico em ambas as concentrações de $\mathrm{M} 77 \mathrm{CDH}$. 
Figura 24 - Consumo de celobiose e produção de ácido celobiônico ao longo do tempo de reação.
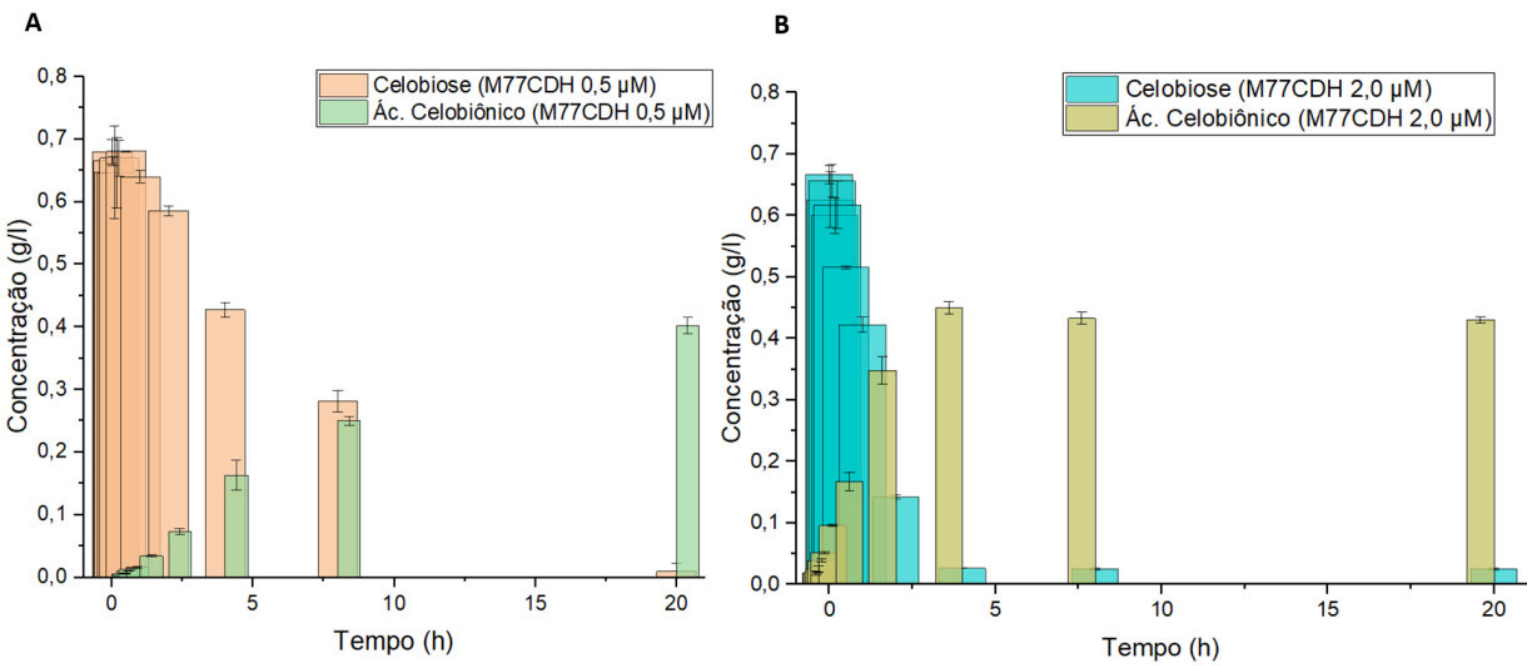

Fonte: Arquivo próprio.

Nota: A: Consumo de celobiose e produção de ácido celobiônico utilizando 0,5 $\mu \mathrm{M}$ de M77CDH.

B: Consumo de celobiose e produção de ácido celobiônico utilizando 2,0 $\mu \mathrm{M}$ de M77CDH.

Em relação a atividade em celooligossacarídeos, nos estudos de Langston et al. (2012) com TtCDH de T. terrestris foi apontado uma menor eficiência catalítica em C3 e C5. Além disso, trabalhos indicam que o valor de $\mathrm{k}_{\mathrm{m}}$ aumenta de acordo com o comprimento do celooligossacarídeo (CHEN et al., 2017; LANGSTON et al., 2012). Foi realizado um experimento preliminar para avaliar a atividade enzimática da $\mathrm{M} 77 \mathrm{CDH}$ sob os diferentes tipos de celooligossacarídeos (Figura 25). Observou-se que, de fato a celobiose é o melhor substrato, seguido de uma crescente atividade enzimática até o celooligossacarídeo C5, diminuindo em $\mathrm{C} 6$ e com menor atividade relativa em $\mathrm{C} 3$.

Por fim, Yoshida et al. (2004) comparou os níveis de transcrição de genes que codificam uma $\beta$-glicosidase e uma $\mathrm{CDH}$ durante o crescimento do fungo $P$. chrysosporium em biomassa. Além disso, comparou a cinética de ambas enzimas em relação ao substrato em comum, celobiose. Os autores confirmaram que o gene da $\mathrm{CDH}$ é induzido em meio suplementado com celobiose, ao passo que o gene codificando a $\beta$-glicosidase é reprimido, indicando que a CDH é naturalmente preferível para a degradação de celobiose. Somado a isso, a $\mathrm{CDH}$ apresentou uma afinidade muito maior por celobiose se comparado à $\beta$ glicosidase (YOSHIDA et al., 2004). Estes argumentos permitem afirmar que a CDH é a enzima favorecida para reagir com a celobiose solúvel no meio reacional durante a hidrólise da lignocelulose, e que provavelmente, auxiliaria com maior eficiência a retirada do produto de inibição de outras celulases. 
Figura 25 - Atividade relativa nos diferentes tipos de celooligossacarídeos.

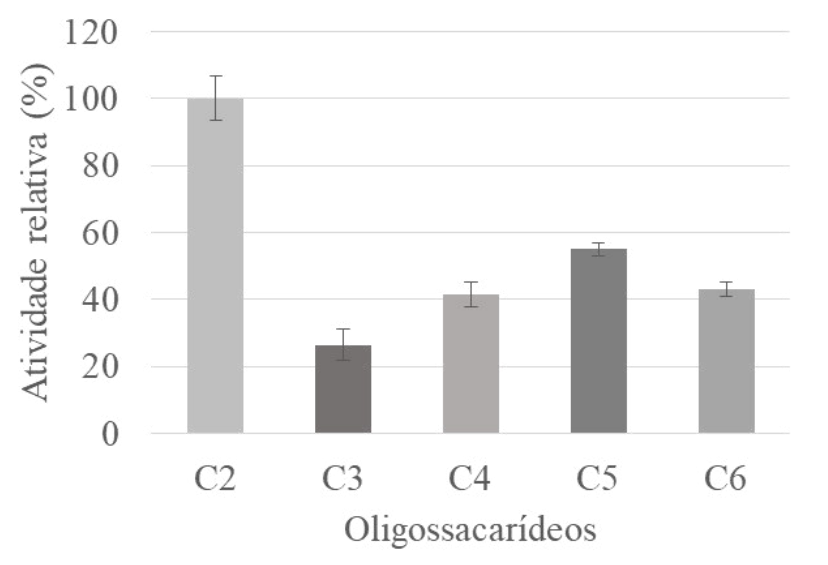

Fonte: Arquivo próprio.

Nota: C2: celobiose; C3: celotriose; C4: celotetraose; C5: celopentaose; C6: celohexaose. Os celooligossacarídeos foram utilizados a uma concentração de $100 \mu \mathrm{M}$ e utilizou-se DCIP como aceptor de elétrons.

A atividade em celobiose foi considerada como $100 \%$.

\subsection{Espalhamento de Raios-X a baixo ângulo (SAXS)}

Para obter o envelope da estrutura, a $\mathrm{M} 77 \mathrm{CDH}$ foi analisada pela técnica de espalhamento de raios-X a baixos ângulos (SAXS). A curva de espalhamento a baixo ângulo teórica, contida na Figura 26A (linha vermelha), foi construída a partir do modelo gerado por homologia e apresentou ser coerente com os dados experimentais. Além disso, o rápido crescimento da curva a baixos valores de $q$ indica a formação de agregados da proteína (MERTENS et al., 2010). Analisando a distribuição de distância entre pares $p(r)$ (Figura 26B) juntamente com a curva de espalhamento foi possível calcular parâmetros como a dimensão molecular máxima $\left(D_{\text {máx }}\right)$ de $11,80 \mathrm{~nm}$, o raio de giro $\left(\mathrm{R}_{\mathrm{g}}\right)$ de $3,45 \mathrm{~nm}$ e o volume molecular de $38 \mathrm{~nm}^{3}$. O raio de giro foi obtido pela aproximação de Guinier respeitando o limite de $q . \mathrm{R}_{\mathrm{g}}<1,3$. A massa molecular indicada pelo $\mathrm{SAXSMoW}(56,1 \mathrm{kDa})$ se mostra um pouco discrepante da massa molecular teórica calculada pela bioinformática (aproximadamente $82 \mathrm{kDa}$ ) (FISCHER et al., 2010). Isso se deve ao fato de que alguns pontos a baixos valores de $q$ foram retirados para análise de SAXS devido ao inconveniente de agregação da proteína, como comentado anteriormente. A região a baixos valores de $q$ é crítica para a determinação da massa molecular, logo essa seria uma razão para a discrepância dos valores obtidos pela análise de SAXS e pela bioinformática (GUINIER, ANDRÉ, 1939; MERTENS et al., 2010).

O modelo estrutural foi gerado por homologia baseado na estrutura cristalográfica da celobiose desidrogenase de Neurospora crassa (Acesso PDB: 4QI7), a qual apresenta uma 
identidade de 57\% com a sequência da M77CDH. Analisando o envelope gerado (Figura 26C), foi possível observar as regiões em que provavelmente se localizam os domínios DH (azul) e CYT (vermelho). Celobioses desidrogenases possuem a característica de grande flexibilidade da sua estrutura, principalmente, devido a presença do linker flexível (HARADA et al., 2017). No envelope gerado foi possível observar regiões que não se adequam exatamente no modelo teórico da estrutura tridimensional e, provavelmente, isso ocorreu devido à alta flexibilidade da estrutura e movimentação dela durante a leitura dos dados de SAXS. Contudo, o envelope obtido através dos dados do SAXS está em acordo com o modelo gerado por homologia.

Figura 26 - Análise do envelope da M77CDH por SAXS.
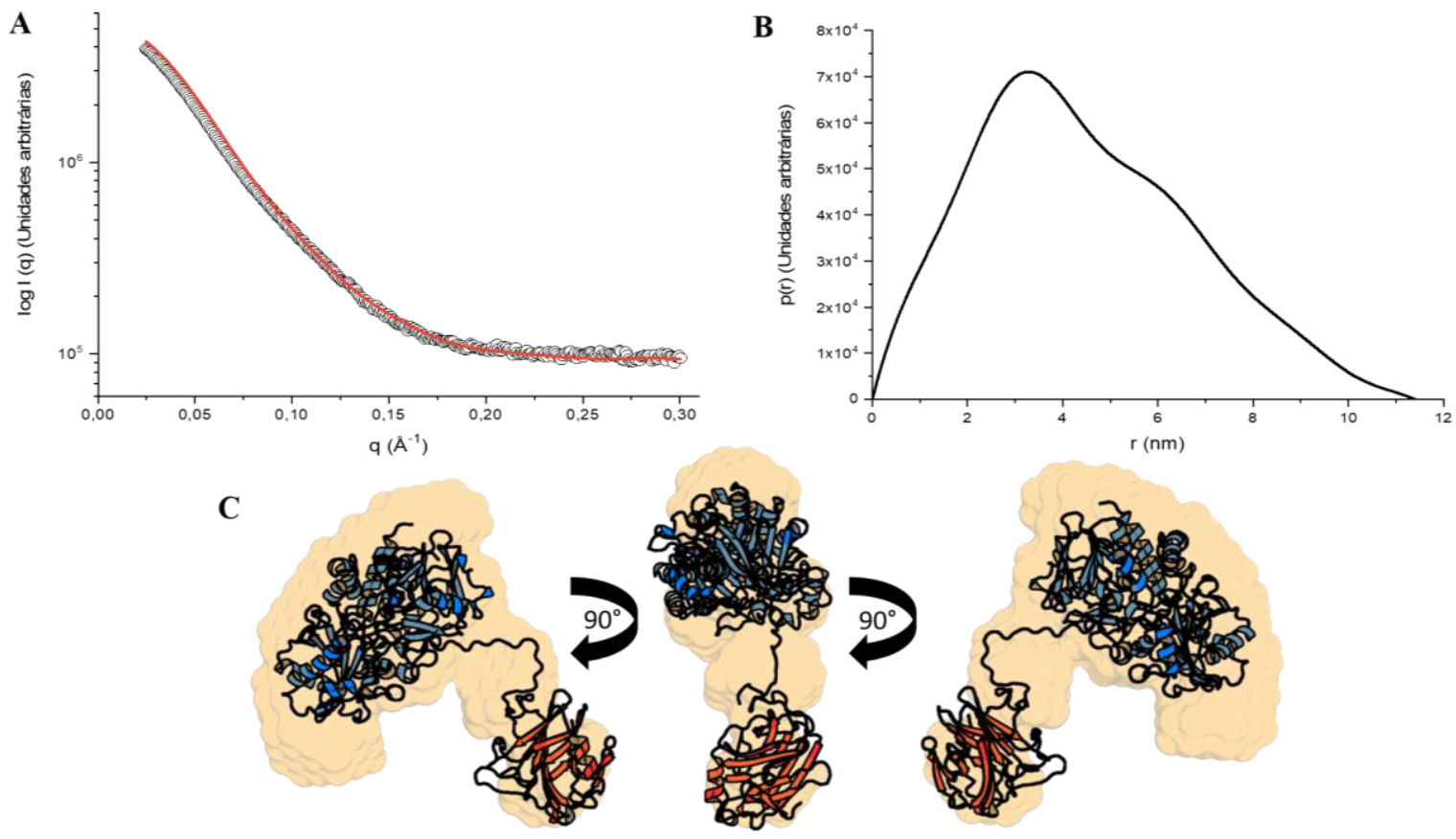

Fonte: Arquivo próprio.

Nota: A: Curva experimental do espalhamento (círculos) e curva teórica calculada a partir do modelo gerado de homologia (linha vermelha).

B: Curva de distribuição entre pares $p(r)$ obtida a partir dos dados experimentais.

C: Estrutura terciária modelada por homologia e inserida no envelope gerado a partir dos dados experimentais obtidos do SAXS.

A proteína é mostrada em vistas laterais.

O domínio DH é mostrado em azul, o CYT em vermelho e o linker em preto. 


\subsection{Ação do extrato bruto de $A$. niveus suplementado com M77CDH em bagaço de cana pré-tratado}

O extrato de A. niveus foi utilizado como fonte de celulases, hemicelulases e algumas LPMOs na hidrólise do bagaço de cana pré-tratado, por se tratar de um fungo termotolerante e seu secretoma ser, em sua maioria, composto por enzimas hidrolíticas (dados não publicados). Logo, analisou-se o efeito da adição da enzima oxidativa, com características termoestáveis, ao coquetel também termoestável e basicamente hidrolítico de A. niveus. Além disso, foi também o objetivo desse experimento realizar uma avaliação preliminar para detectar o efeito da atividade da M77CDH (variando de 0,025 a $25 \mu \mathrm{g} / \mathrm{ml}$ ) na degradação da biomassa. O bagaço de cana utilizado nos ensaios de hidrólise continha menor teor de xilana $(13,063 \%$ em massa) e maior conteúdo de celulose $(49,255 \%)$ e lignina $(27,871 \%)$, devido as características que o pré-tratamento hidrotérmico (LHW) promove na biomassa (ZHUANG et al., 2016).

De acordo com a Figura 27, foi possível detectar que o aumento da concentração de M77CDH no coquetel utilizado na hidrólise apresentou uma diminuição na liberação de açúcares redutores, em que, $25 \mu \mathrm{g} / \mathrm{ml}$ de $\mathrm{M} 77 \mathrm{CDH}$ promoveu uma redução de aproximadamente 5 vezes do conteúdo de extremidades redutoras detectadas. Esse fenômeno já foi demonstrado em estudos de Bey et al. (2011). Os autores concluem que, na situação em que há um coquetel enzimático contendo, entre outras enzimas, a $\beta$-glicosidase, o produto final da degradação da celobiose será resíduos de glicose, que contém extremidade redutora. Já no cenário com a adição de CDHs no coquetel enzimático, a celobiose será oxidada a uma lactona, que posteriormente é hidrolisada a um ácido celobiônico (Figura 28). Em vista disso, ocorre a liberação de extremidades não redutoras (ácido celobiônico/glucônico) pela $\mathrm{CDH}$, composto que não é detectado pelo método de DNS (BEY et al., 2011).

Portanto, a ação da M77CDH está promovendo a oxidação da celobiose, proveniente da degradação do bagaço de cana, em ácido celobiônico, reduzindo a detecção pelo DNS, como mostrado na Figura 27. 
Figura 27 - Análise do total de açúcares redutores liberados com a hidrólise do bagaço de cana pré-tratado.

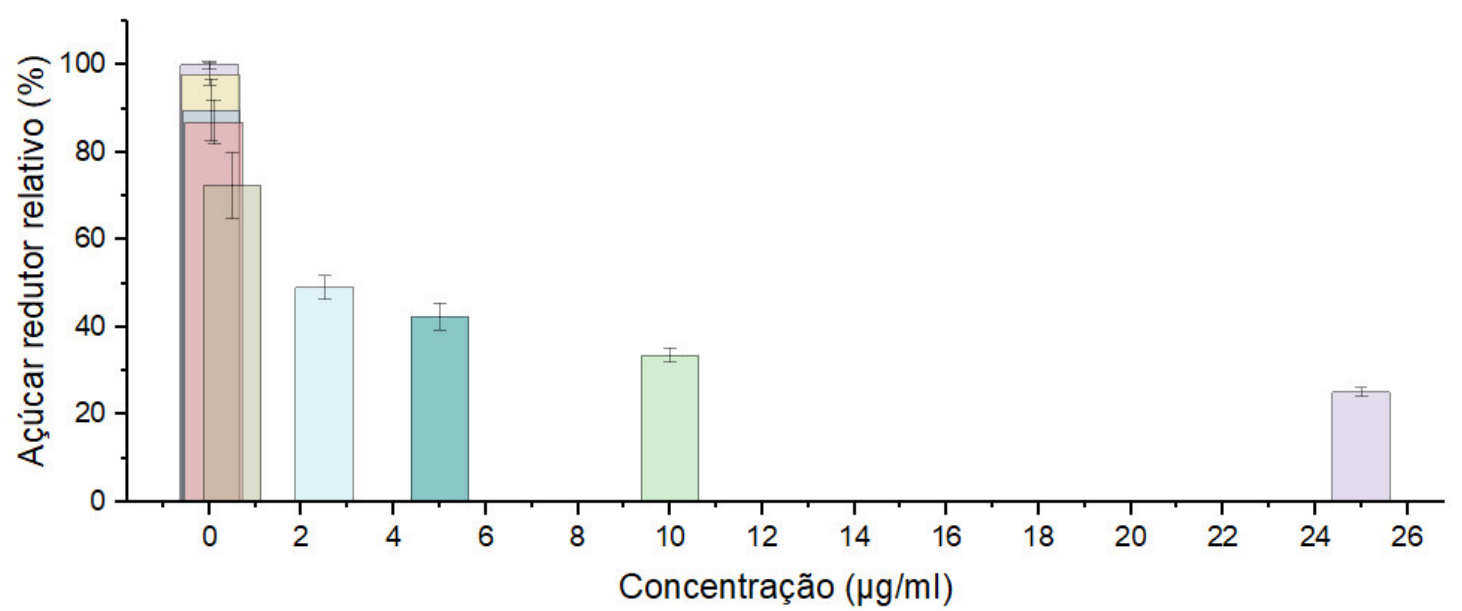

Fonte: Arquivo próprio.

Nota: Utilizou-se o extrato bruto de A. niveus $(5 \mathrm{mg} / \mathrm{g}$ substrato) suplementado com M77CDH em várias proporções $(0,025 \mathrm{a} 25 \mu \mathrm{g} / \mathrm{ml})$. A reação contendo somente o extrato de A. niveus foi considerado como $100 \%$. Um controle sem a M77CDH foi feito para cada condição.

As médias são valores de triplicatas experimentais.

As barras de erro são o desvio padrão referentes às triplicatas.

Bey et al. (2011) concluem que o DNS não é um bom método para analisar a degradação da celulose por $\mathrm{CDH}$, pelo fato deste reagente não detectar outros produtos além dos que possuem extremidade redutora. Porém, foi um método válido nesse estudo para analisar, de forma preliminar, o efeito da concentração da $\mathrm{M} 77 \mathrm{CDH}$ no processo de despolimerização da biomassa. Em relação ao rendimento total de hidrólise, Bey et al. (2011) demonstrou que a adição da enzima $\mathrm{CDH}$ a reação promove um aumento da hidrólise geral da biomassa, pois, foi possível detectar uma maior concentração de compostos como ácido glucônico, xilose, galactose e arabinose (detectados por cromatografia de troca aniônica de alta performance - HPAE) em comparação ao controle (BEY et al., 2011).

Figura 28 - Via hidrolítica ou oxidativa para a clivagem da celobiose.

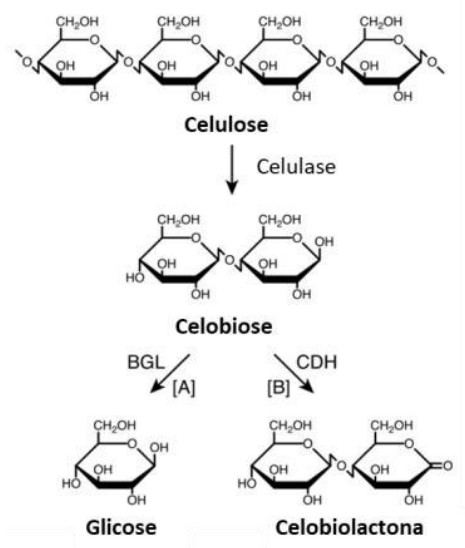

Fonte: Adaptado de (YOSHIDA et al., 2004).

Nota: A: Via hidrolítica e B: Via oxidativa

BGL: $\beta$-glicosidase e CDH: celobiose desidrogenase 
Estudos comparando o grau de inibição entre celobiose e celobionato (forma em solução do ácido celobiônico) em celobiohidrolases (CBHI de T. reesei), coquetel de celulases (Accelerase 1500) e CDH de N. crassa, afirmaram que celobionato é menos inibitório para a CBHI e Accelerase 1500 quando comparado à celobiose. Além disso, que o celobionato não promove nenhuma inibição em $\mathrm{CDH}$ (somente a forma lactona é inibitória para CDH) (HILDEBRAND et al., 2016). Amenizar a inibição de enzimas chave, utilizadas na despolimerização da biomassa é uma estratégia interessante para melhorar o rendimento global no processo de conversão. Sendo assim, a aplicação da M77CDH tem potencial de aumentar o desempenho dos coquetéis enzimáticos pelo mecanismo de diminuir o efeito inibitório promovido pela celobiose (HILDEBRAND et al., 2016), além de outras vantagens, como atuar em conjunto com LPMOs e auxiliar enzimas ligninolíticas.

\subsection{Ação do coquetel de celulases suplementado com LPMO e M77CDH em PASC}

Visando a avaliação da ação da $\mathrm{M77CDH}$ na sacarificação do substrato sintético

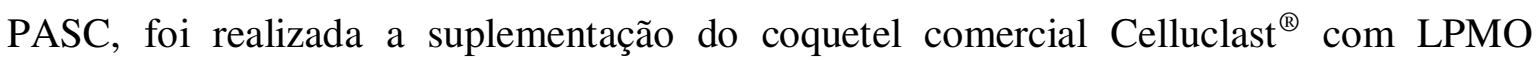
bacteriana e com as concentrações de 0,5 e 2,0 $\mu \mathrm{M}$ de M77CDH (Figura 29). Foi possível observar que em ambas as reações contendo a $\mathrm{M} 77 \mathrm{CDH}$ houve a produção de ácido celobiônico, apresentando uma maior produção $(0,62 \mathrm{~g} / \mathrm{L})$ na reação contendo $2,0 \mu \mathrm{M}$ da enzima. Além disso, a adição da $\mathrm{M} 77 \mathrm{CDH}$ resultou no redirecionamento da reação uma vez que passou a aumentar a produção de ácido celobiônico. Os valores de glicose permaneceram praticamente constantes em relação ao controle e as condições adicionando $\mathrm{M} 77 \mathrm{CDH}$, enquanto que a concentração de celobiose diminuiu com a adição de M77CDH. Apesar das reações com M77CDH não terem potencializado a liberação de produtos da sacarificação (açúcares + ácido celobiônico), a produção de ácido celobiônico também é interessante no contexto das biorrefinarias como um produto de maior valor agregado em relação ao etanol, sendo uma ótima alternativa para comercialização e como um coproduto de origem renovável (CANNELLA et al., 2012; LI et al., 2015). 
Figura 29 - Sacarificação do PASC pelo coquetel comercial Celluclast ${ }^{\circledR}$ suplementado com LPMO bacteriana e $\mathrm{M} 77 \mathrm{CDH}$.

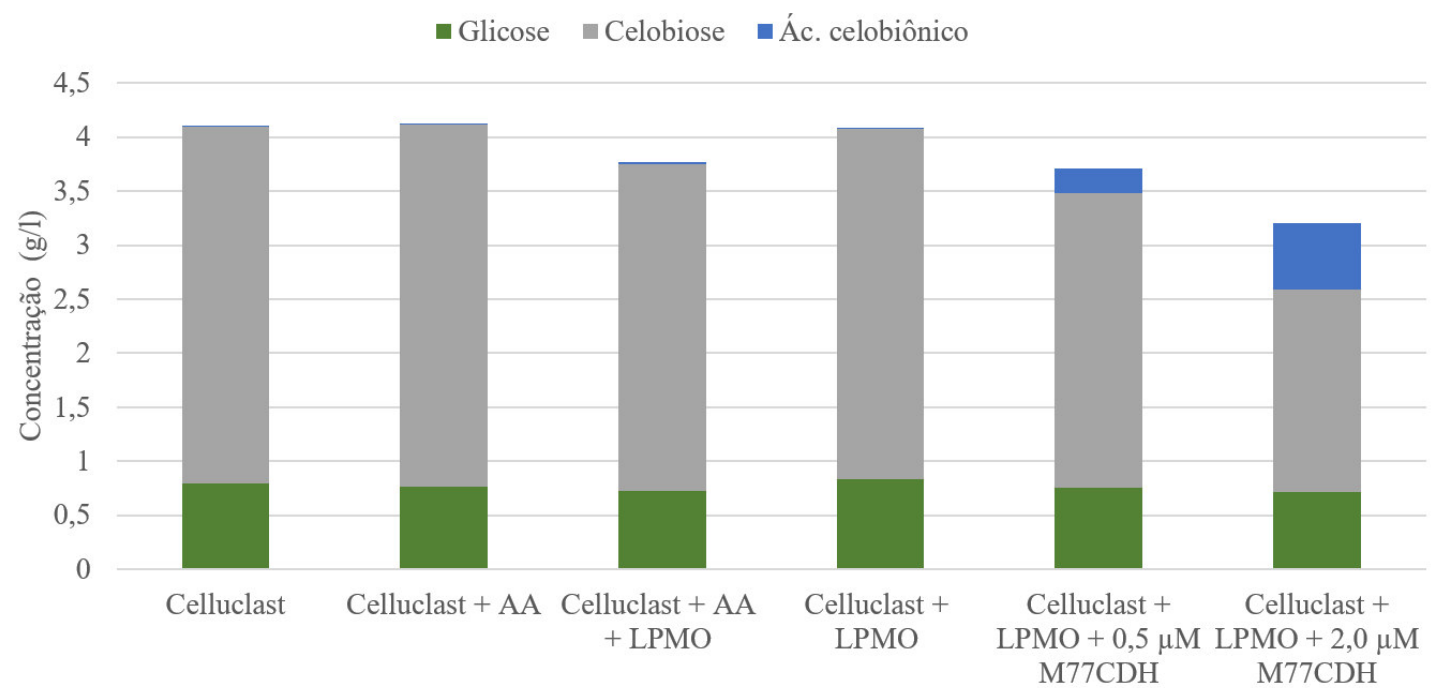

Fonte: Arquivo próprio.

Nota: AA: Ácido ascórbico na concentração final de $1 \mathrm{mM}$.

M77CDH: utilizada nas concentrações de 0,5 e 2,0 $\mu \mathrm{M}$. 


\section{CONCLUSÃO}

A enzima oxidativa celobiose desidrogenase M77CDH foi expressa heterologamente e produzida em $A$. nidulans com sucesso. Sua caracterização bioquímica revelou ser uma enzima que apresenta atividade a temperaturas elevadas $\left(65^{\circ} \mathrm{C}\right)$ e estabilidade a $50{ }^{\circ} \mathrm{C}$ por períodos acima de 7 horas. A M77CDH recombinante apresentou características incomuns às reportadas na literatura até o momento, como uma atividade relevante do domínio CYT a pHs alcalinos e valores de eficiência catalítica em celobiose potencial entre as CDHs da Classe IIB. Além disso, provavelmente apresentou atuação conjunta com o coquetel enzimático de A. niveus, pois reduziu os níveis de liberação de açúcar redutor pela produção de ácido celobiônico e/ou glucônico. Por fim, a M77CDH foi capaz de produzir ácido celobiônico em reação com celobiose e com o substrato PASC, neste último em atuação com coquetel de celulases (Celluclast ${ }^{\circledR}$ ) e LPMO. 


\section{REFERÊNCIAS}

ANDER, P.; SENA-MARTINS, G.; DUARTE, J. C. Influence of cellobiose oxidase on peroxidases from Phanerochaete chrysosporium. Biochemical Journal, v. 293, n. 2, p. 431435, 1993.

BALDWIN, M. A. Protein Identification by Mass Spectrometry. Molecular \& Cellular Proteomics 3.1, p. 1-9, 2004.

BAMINGER, U. et al. A simple assay for measuring cellobiose dehydrogenase activity in the presence of laccase. Journal of Microbiological methods, v. 35, p. 253-259, 1999.

BAMINGER, U. et al. Purification and Characterization of Cellobiose Dehydrogenase from the Plant Pathogen Sclerotium (Athelia) rolfsii. Applied and Environmental Microbiology, v. 67, n. 4, p. 1766-1774, 2001.

BATEMAN, A. et al. UniProt: The universal protein knowledgebase. Nucleic Acids Research, v. 45, n. D1, p. D158-D169, 2017.

BEY, M. et al. Heterologous expression of Pycnoporus cinnabarinus cellobiose dehydrogenase in Pichia pastoris and involvement in saccharification processes. Microbial Cell Factories, v. 10, n. 1, p. 1-15, 2011.

BEY, M. et al. Cello-oligosaccharide oxidation reveals differences between two lytic polysaccharide monooxygenases (Family GH61) from Podosporaanserina. Applied and Environmental Microbiology, v. 79, n. 2, p. 488-496, 2013.

BODENHEIMER, A. M. et al. Structural studies of Neurospora crassa LPMO9D and redox partner CDHIIA using neutron crystallography and small-angle scattering. Carbohydrate Research, v. 448, n. 4, p. 5-9, 2017.

BRADFORD, M. M. A rapid and sensitive method for the quantitation of microgram quantities of protein utilizing the principle of protein-dye binding. Analytical biochemistry, v. 72, p. 248-254, 1976.

BRENELLI, L. et al. Laccase-derived lignin compounds boost cellulose oxidative enzymes AA9. Biotechnology for Biofuels, v. 11, n. 1, p. 1-12, 2018.

CANEVASCINI, G.; BORER, P.; DREYER, J. -L. Cellobiose dehydrogenases of Sporotrichum (Chrysosporium) thermophile. European Journal of Biochemistry, v. 198, n. 1, p. 43-52, 1991.

CANNELLA, D. et al. Production and effect of aldonic acids during enzymatic hydrolysis of lignocellulose at high dry matter content. Biotechnology for Biofuels, v. 5, n. 26, p. 1$10,2012$.

CANTAREL, B. L. et al. The Carbohydrate-Active EnZymes database (CAZy): an expert resource for Glycogenomics. Nucleic Acids Res., v. 37, p. 233-238, 2009.

CHEN, K. et al. Cellobiose dehydrogenase from Volvariella volvacea and its effect on the saccharification of cellulose. Process Biochemistry, v. 60, n. 1, p. 52-58, 2017.

COUTURIER, M. et al. Lytic xylan oxidases from wood-decay fungi unlock biomass degradation. Nature Chemical Biology, v. 14, n. 3, p. 306-310, 2018.

COX, M. C. et al. Spectroscopic identification of the haem ligands of cellobiose oxidase. 
FEBS Letters, v. 307, n. 2, p. 233-236, 1992.

DAMÁSIO, A. R. D. L. et al. Heterologous expression of an Aspergillus niveus xylanase GH11 in Aspergillus nidulans and its characterization and application. Process Biochemistry, v. 46, p. 1236-1242, 2011.

DAMÁSIO, A. R. D. L. et al. Improvement of fungal arabinofuranosidase thermal stability by reversible immobilization. Process Biochemistry, v. 47, n. 12, p. 2411-2417, 2012a.

DAMÁSIO, A. R. L. et al. Functional characterization and oligomerization of a recombinant xyloglucan-specific endo-beta-1,4-glucanase (GH12) from Aspergillus niveus. Biochimica et Biophysica Acta - Proteins and Proteomics, v. 1824, n. 3, p. 461-467, 2012 b.

DE VRIES, R. P. et al. Synergy between enzymes from Aspergillus involved in the degradation of plant cell wall polysaccharides. Carbohydrate Research, v. 327, n. 4, p. 401-410, 2000.

DESAI, S. H. et al. Isobutanol production from cellobionic acid in Escherichia coli. Microbial Cell Factories, v. 14, n. 1, p. 1-10, 2015.

DODD, D.; CANN, I. K. Enzymatic deconstruction of xylan for biofuel production. Glob Change Biol Bioenergy, v. 1, n. 2, p. 2-17, 2009.

EIJSINK, V. G. H. et al. Towards new enzymes for biofuels: lessons from chitinase research. Trends in Biotechnology, v. 26, n. 5, p. 228-235, 2008.

FAN, Z. et al. A Novel Biochemical Route for Fuels and Chemicals Production from Cellulosic Biomass. Plos One, v. 7, n. 2, p. 1-8, 2012.

FINN, R. D. et al. The Pfam protein families database: Towards a more sustainable future. Nucleic Acids Research, v. 44, n. 1, p. 279-285, 2016.

FISCHER, H. et al. Determination of the molecular weight of proteins in solution from a single small-angle X-ray scattering measurement on a relative scale. Journal of Applied Crystallography, v. 43, n. 1, p. 101-109, 2010.

FORSBERG, Z. et al. Cleavage of cellulose by a cbm33 protein. Protein Science, v. 20, n. 9, p. 1479-1483, 2011.

GIBSON, D. G. Synthesis of DNA fragments in yeast by one-step assembly of overlapping oligonucleotides. Nucleic Acids Research, v. 37, n. 20, p. 6984-6990, 2009.

GIBSON, D. G. Enzymatic assembly of overlapping DNA fragments. Methods in Enzymology, v. 498, p. 349-361, 2011.

GOMES, E. et al. Enzimas termoestáveis: fontes, produção e aplicação industrial. Quimica Nova, v. 30, n. 1, p. 136-145, 2007.

GOMES, E. et al. Applications and Benefits of Thermophilic Microorganisms and Their Enzymes for Industrial Biotechnology. In: SCHMOLL, M.; DATTENBOCK, C. (Eds.). . Gene Expression Systems in Industrial Fungi: Advancements and Applications. São Jose do Rio Preto , SP: Springer, 2016. p. 459-492.

GRINHUT, T. et al. Involvement of ligninolytic enzymes and Fenton-like reaction in humic acid degradation by Trametes sp. Applied Microbiology and Biotechnology, v. 91, n. 4, p. 1131-1140, 2011. 
GUDYNAITE-SAVITCH, L.; WHITE, T. C. Fungal Biotechnology for Industrial Enzyme Production: Focus on (Hemi)cellulase Production Strategies, Advances and Challenges. In: Gene Expression Systems in Industrial Fungi: Advancements and Applications. Canada: Springer Berlin Heidelberg, 2016. p. 395.

GUINIER, ANDRÉ. La diffraction des rayons $\mathrm{X}$ aux très petits angles : application à l'étude de phénomènes ultramicroscopiques. Ann. Phys., v. 11, n. 12, p. 161-237, 1939.

HALLBERG, M. B. et al. Crystal structure of the flavoprotein domain of the extracellular flavocytochrome cellobiose dehydrogenase. Journal of Molecular Biology, v. 315, n. 3, p. 421-434, 2002.

HAMMEL, K. E. et al. Reactive oxygen species as agents of wood decay by fungi. Enzyme and Microbial Technology, v. 30, n. 4, p. 445-453, 2002.

HAMMERSLEY, A. P. FIT2D: A multi-purpose data reduction, analysis and visualization program. Journal of Applied Crystallography, v. 49, p. 646-652, 2016.

HARADA, H. et al. Interdomain flip-flop motion visualized in flavocytochrome cellobiose dehydrogenase using high-speed atomic force microscopy during catalysis. Chem. Sci., v. 8, p. 6561-6565, 2017.

HARREITHER, W. et al. Cellobiose Dehydrogenase from the Ligninolytic Basidiomycete Ceriporiopsis subvermispora. Applied and Environmental Microbiology, v. 75, n. 9, p. 2750-2757, 2009.

HARREITHER, W. et al. Catalytic properties and classification of cellobiose dehydrogenases from ascomycetes. Applied and Environmental Microbiology, v. 77, n. 5, p. 1804-1815, 2011.

HARREITHER, W. et al. Recombinantly produced cellobiose dehydrogenase from Corynascus thermophilus for glucose biosensors and biofuel cells. Biotechnology Journal, v. 7, n. 11, p. 1359-1366, 2012.

HEMSWORTH, G. R. et al. Discovery and characterization of a new family of lytic polysaccharide mono-oxygenases. Nat Chem Biol., v. 10, n. 2, p. 122-126, 2014.

HENRIKSSON, G.; JOHANSSON, G.; PETTERSSON, G. Is cellobiose oxidase from Phanerochaete chrysosporium a lignin degrading enzyme? Biochimica et Biophysica Acta - Bioenergetics, v. 1144, n. 2, p. 184-190, 1993.

HENRIKSSON, G.; PETTERSSEN, G.; JOHANSSON, G. A critical review of cellobiose dehydrogenase. Journal of Biotechnology, v. 79, n. 1, p. 93-113, 2000.

HILDEBRAND, A. et al. Cellobionic acid inhibition of cellobiohydrolase I and cellobiose dehydrogenase. Biochemical Engineering Journal, v. 109, p. 236-242, 2016.

HILDÉN, L. et al. Do the extracellular enzymes cellobiose dehydrogenase and manganese peroxidase form a pathway in lignin biodegradation? FEBS Letters, v. 477, n. 1-2, p. 79$83,2000$.

HORN, S. J. et al. Costs and benefits of processivity in enzymatic degradation of recalcitrant polysaccharides. Proceedings of the National Academy of Sciences of the United States of America, v. 103, n. 6, p. 18089-18094, 2006.

HORN, S. J. et al. Novel enzymes for the degradation of cellulose Novel. Biotechnology for Biofuels, v. 45, n. 5, p. 1-12, 2012. 
IGARASHI, K. et al. Cellobiose Dehydrogenase from the Fungi Phanerochaete chrysosporium and Humicola. The Journal of biological chemistry, v. 274, n. 6, p. 33383344, 1999.

JEANMOUGIN, F. et al. Multiple sequence alignment with Clustal X. Trends in Biochemical Sciences, v. 23, n. 10, p. 403-405, 1998.

KAMESHWAR, A. K. S.; QIN, W. Lignin degrading fungal enzymes. In: FANG, Z.; SMITH, R. L. (Eds.). . Production of Biofuels and Chemicals from Lignin. 1. ed. Canada: Springer Science, 2016. p. 81-130.

KELLY, S. M.; JESS, T. J.; PRICE, N. C. How to study proteins by circular dichroism. Biochimica et Biophysica Acta - Proteins and Proteomics, v. 1751, n. 2, p. 119-139, 2005.

KOLENOVA, K.; VRSANSKA, M.; BIELY, P. Mode of action of endo-beta-1,4-xylanases of families 10 and 11 on acidic xylooligosaccharides. Journal of Biotechnology, v. 121, n. 3, p. 338-345, 2006.

KOZIN, M. B.; SVERGUN, D. I. Automated matching of high- and low-resolution structural models. Journal of Applied Crystallography, v. 34, n. 1, p. 33-41, 2001.

KRAHE, M.; ANTRANIKIAN, G.; MÄIRKL, H. Fermentation of extremophilic microorganisms. FEMS Microbiology Reviews, v. 18, n. 2-3, p. 271-285, 1996.

KREMER, S. M.; WOOD, P. M. Production of Fenton's reagent by cellobiose oxidase from cellulolytic cultures of Phanerochaete chrysosporium. European Journal of Biochemistry, v. 208, n. 3, p. 807-814, 1992.

KUMAR, H. D.; SWATI, S. Modern Concepts of Microbiology. 2. ed. Panama city: Vikas Publishing House Pvt. Ltd., 2004.

KUMAR, S.; NUSSINOV, R. How do thermophilic proteins deal with heat? Cell. Mol. Life Sci., v. 58, n. 9, p. 1216-1233, 2001.

KUWANO, T.; SHIRATAKI, C.; ITOH, Y. Comparison between polyethylene glycol- and polyethylenimine-mediated transformation of Aspergillus nidulans. Curr Genet, v. 54, n. 2, p. $95-103,2008$.

LANGSTON, J. A. et al. Oxidoreductive cellulose depolymerization by the enzymes cellobiose dehydrogenase and glycoside hydrolase 61. Applied and Environmental Microbiology, v. 77, n. 19, p. 7007-7015, 2011.

LANGSTON, J. A. et al. Cloning, expression, and characterization of a cellobiose dehydrogenase from Thielavia terrestris induced under cellulose growth conditions. Biochimica et Biophysica Acta - Proteins and Proteomics, v. 1824, n. 6, p. 802-812, 2012.

LEVASSEUR, A. et al. FOLy: An integrated database for the classification and functional annotation of fungal oxidoreductases potentially involved in the degradation of lignin and related aromatic compounds. Fungal Genetics and Biology, v. 45, n. 5, p. 638-645, 2008.

LEVASSEUR, A. et al. Expansion of the enzymatic repertoire of the CAZy database to integrate auxiliary redox enzymes. Biotechnology for Biofuels, v. 6, n. 1, p. 1-14, 2013.

LI, X. et al. Cellobionic acid utilization: From Neurospora crassa to Saccharomyces cerevisiae. Biotechnology for Biofuels, v. 8, n. 1, p. 1-9, 2015. 
LOMBARD, V. et al. The carbohydrate-active enzymes database (CAZy). Nucleic Acids Res, v. 42, n. 1, p. 490-495., 2014.

LUDWIG, R. et al. Cellobiose dehydrogenase: A versatile catalyst for electrochemical applications. ChemPhysChem, v. 11, n. 13, p. 2674-2697, 2010.

MA, S. et al. Molecular and catalytic properties of fungal extracellular cellobiose dehydrogenase produced in prokaryotic and eukaryotic expression systems. Microbial Cell Factories, v. 16, n. 1, p. 37, 2017.

MADIGAN, M. T.; OREN, A. Thermophilic and halophilic extremophiles. Curr. Opin. Microbiol., v. 2, n. 1, p. 265, 1999.

MARTINS E SILVA, J. A. Porfirinas e Porfírias. Revista das Ciências Médicas da Universidade de Lourenço Marques, v. 5, p. 1-55, 1970.

MASON, M. G. et al. The heme domain of cellobiose oxidoreductase: A one-electron reducing system. Biochimica et Biophysica Acta - Bioenergetics, v. 1604, n. 1, p. 47-54, 2003.

MERTENS, H. D. T. et al. Structural characterization of proteins and complexes using small-angle X-ray solution scattering. Journal of Structural Biology, v. 172, n. 1, p. 128$141,2010$.

MICHAELIS, L.; MENTEN, M. L. The Kinetics of Invertase Action. Biochem Z, v. 49, n. 1, p. 333-369, 1913.

MILLER, G. L. Use of Dinitrosalicylic Acid Reagent for Determination of Reducing Sugar. Analytical Chemistry, v. 31, n. 3, p. 426-428, 1959.

MORGENSTERN, I.; POWLOWSKI, J.; TSANG, A. Fungal cellulose degradation by oxidative enzymes: From dysfunctional GH61 family to powerful lytic polysaccharide monooxygenase family. Briefings in Functional Genomics, v. 13, n. 6, p. 471-481, 2014.

MOZHAEV, V. Mechanism-based strategies for protein thermo- stabilization. Trends Biotechnol., v. 11, p. 88-95, 1993.

MÜLLER, M. et al. High-yield recombinant xylanase production by Aspergillus nidulans under pyridoxine limitation. Journal of Industrial Microbiology \& Biotechnology, v. 41, p. 1563-1570, 2014.

NEW ENGLAND BIOLABS. What is the difference between PNGase F and Endo H? Disponível em: <https://www.neb.com/faqs/0001/01/01/what-is-the-difference-betweenpngase-f-and-endo-h>. Acesso em: 9 abr. 2018.

NIELSEN, H. Predicting Secretory Proteins with SignalP. Protein Function Prediction, v. 1611, p. 59-73, 2017.

PARDO-PLANAS, O.; PRADE, R. A.; WILKINS, M. R. High-yield production of aryl alcohol oxidase under limited growth conditions in small-scale systems using a mutant Aspergillus nidulans strain. Journal of Industrial Microbiology \& Biotechnology, v. 44, n. 2, p. 247-257, 2016.

PAYNE, C. M. et al. Fungal cellulases. Chemical Reviews, v. 115, n. 3, p. 1308-1448, 2015.

PHILLIPS, C. M. et al. Cellobiose Dehydrogenase and a Copper-Dependent Polysaccharide 
Monooxygenase Potentiate Cellulose Degradation by Neurospora crassa. ACS Chemical Biology, v. 6, n. 1, p. 1399-1406, 2011.

PHILLIPS, J. N. Physicochemical properties of porphyrins. Comp Biochem, v. 9, n. 1, p. 34-72, 1963.

POLIZELI, M. L. T. M. et al. Xylanases from fungi: Properties and industrial applications. Applied Microbiology and Biotechnology, v. 67, n. 5, p. 577-591, 2005.

QUINLAN, R. J. et al. Insights into the oxidative degradation of cellulose by a copper metalloenzyme that exploits biomass components. Proceedings of the National Academy of Sciences, v. 108, n. 37, p. 15079-15084, 2011.

RAMACHANDRAN, S. et al. Gluconic acid: Properties, applications and microbial production. Food Technology and Biotechnology, v. 44, n. 2, p. 185-195, 2006.

RATANAKHANOKCHAI, K. et al. Paenibacillus curdlanolyticus Strain B-6 Multienzyme Complex: A Novel System for Biomass Utilization. In: MATOVIC, M. D. (Ed.). . Biomass Now - Cultivation and Utilization. 1. ed. Canada: IntechOpen, 2013. p. 370-394.

REZENDE, C. et al. Chemical and morphological characterization of sugarcane bagasse submitted to a delignification process for enhanced enzymatic digestibility. Biotechnology for Biofuels, v. 4, n. 54, p. 1-18, 2011.

RODRÍGUEZ-ZÚÑIGA, U. F. et al. Lignocellulose pretreatment technologies affect the level of enzymatic cellulose oxidation by LPMO. Green Chem., v. 17, n. 5, p. 2896-2903, 2015 .

ROY, B. P. et al. Creation of metal-complexing agents, reduction of manganese dioxide, and promotion of manganese peroxidase-mediated $\mathrm{Mn}(\mathrm{III})$ production by cellobiose:quinone oxidoreductase from Trametes versicolor. Journal of Biological Chemistry, v. 269, n. 31, p. 19745-19750, 1994.

SABBADIN, F. et al. An ancient family of lytic polysaccharide monooxygenases with roles in arthropod development and biomass digestion. Nature Communications, v. 9, n. 1, p. 0 38, 2018.

SCHOU, C.; CHRISTENSEN, M. H.; SCHULEIN, M. Characterization of a cellobiose dehydrogenase from Humicola insolens. Biochem. J, v. 330, p. 565-571, 1998.

SEGATO, F. et al. High-yield secretion of multiple client proteins in Aspergillus. Enzyme and Microbial Technology, v. 51, p. 100-106, 2012.

SHALlOM, D.; SHOHAM, Y. Microbial hemicellulases. Curr Opin Microbiol., v. 6, n. 3, p. 219-228, 2003.

SHAPIRO, A. L.; VIÑUELA, E.; V. MAIZEL JR., J. Molecular weight estimation of polypeptide chains by electrophoresis in SDS-polyacrylamide gels. Biochemical and Biophysical Research Communications, v. 28, n. 5, p. 815-820, 1967.

SHEVCHENKO, A. et al. Mass Spectrometric Sequencing of Proteins from Silver-Stained Polyacrylamide Gels Mass Spectrometric Sequencing of Proteins from Silver-Stained Polyacrylamide Gels. v. 68, n. 5, p. 850-858, 1996.

SOCCOL, C. et al. Bioethanol from lignocelluloses: Status and perspectives in Brazil. Bioresource Technology, v. 101, n. 13, p. 4820-4825, 2010. 
SØRENSEN, A. et al. Fungal Beta-glucosidases: a bottleneck in industrial use of lignocellulosic materials. Biomolecules, v. 3, n. 3, p. 612-31, 2013.

SUBRAMANIAM, S. S.; NAGALLA, S. R.; RENGANATHAN, V. Cloning and Characterization of a Thermostable Cellobiose Dehydrogenase from Sporotrichum thermophile. Archives of Biochemistry and Biophysics, v. 365, n. 2, p. 223-230, 1999.

SULEJ, J. et al. Characterization of cellobiose dehydrogenase and its FAD-domain from the ligninolytic basidiomycete Pycnoporus sanguineus. Enzyme and Microbial Technology, v. 53, n. 6-7, p. 427-437, $2013 \mathrm{a}$.

SULEJ, J. et al. Cellobiose dehydrogenase from the ligninolytic basidiomycete Phlebia lindtneri. Process Biochemistry, v. 48, n. 11, p. 1715-1723, 2013 b.

SULEJ, J. et al. Characterization of Cellobiose Dehydrogenase from a Biotechnologically Important Cerrena unicolor strain. Appl Biochem Biotechnol, p. 1638-1658, 2015.

SUN, F. F. et al. Accessory enzymes influence cellulase hydrolysis of the model substrate and the realistic lignocellulosic biomass. Enzyme and Microbial Technology, v. 79-80, p. 42-48, 2015.

SÜTZL, L. et al. Multiplicity of enzymatic functions in the CAZy AA3 family. Applied Microbiology and Biotechnology, v. 102, n. 6, p. 2477-2492, 2018.

SVERGUN, D. I. Determination of the regularization parameter in indirect-transform methods using perceptual criteria. Journal of Applied Crystallography, v. 25, n. pt 4, p. 495-503, 1992.

SVERGUN, D. I. Restoring Low Resolution Structure of Biological Macromolecules from Solution Scattering Using Simulated Annealing. Biophysical Journal, v. 76, n. 6, p. 28792886, 1999.

SWEENEY, M.; VLASENKO, E.; ABBATE, E. Methods for increasing hydrolysis of cellulosic material in the presence of cellobiose dehydogenase.Bagsværd (DK)European Patent Specification, , 2010.

SYGMUND, C. et al. Characterization of the two Neurospora crassa cellobiose dehydrogenases and their connection to oxidative cellulose degradation. Applied and Environmental Microbiology, v. 78, n. 17, p. 6161-6171, 2012.

TAN, T.-C. et al. Structural basis for cellobiose dehydrogenase action during oxidative cellulose degradation. Nature Communications, v. 6, n. 9, p. 7542, 2015.

TIEN, M.; KIRK, T. K. Lignin-degrading enzyme from Phanerochaete chrysosporium: Purification, characterization, and catalytic properties of a unique $\mathrm{H}(2) \mathrm{O}(2)$-requiring oxygenase. Proceedings of the National Academy of Sciences of the United States of America, v. 81, n. 2, p. 2280-2284, 1984.

TURBE-DOAN, A. et al. Heterologous production of cellobiose dehydrogenases from the basidiomycete Coprinopsis cinerea and the ascomycete Podospora anserina and their effect on saccharification of wheat straw. Applied Microbiology and Biotechnology, v. 97, n. 11, p. 4873-4885, 2013.

VAAJE-KOLSTAD, G. et al. An oxidative enzyme boosting the enzymatic conversion of recalcitrant polysaccharides. Science, v. 330, n. 219, p. 219-222, 2010.

VALLI, K.; WARIISHI, H.; GOLD, M. H. Oxidation of Monomethoxylated Aromatic 
Compounds by Lignin Peroxidase: Role of Veratryl Alcohol in Lignin Biodegradation. Biochemistry, v. 29, n. 37, p. 8535-8539, 1990.

VÁRNAI, A. et al. Carbohydrate-binding modules of fungal cellulases: occurrence in nature, function, and relevance in industrial bio- mass conversion. Advances in applied microbiology., v. 88, n. 6, p. 103-65, 2014.

VIEILLE, C.; ZEIKUS, G. J. Hyperthermophilic enzymes: sources, uses, and molecular mechanisms for thermostability. Microbiology and Molecular Biology Reviews, v. 65, 2001.

VU, V. V. et al. A family of starch-active polysaccharide monooxygenases. Proceedings of the National Academy of Sciences, v. 111, n. 38, p. 13822-13827, 2014.

WATERHOUSE, A. et al. SWISS-MODEL: Homology modelling of protein structures and complexes. Nucleic Acids Research, v. 46, n. W1, p. W296-W303, 2018.

WEBB, B.; SALI, A. Comparative protein structure modeling using MODELLER. Current Protocols in Bioinformatics, v. 2016, n. June, p. 5.6.1-5.6.37, 2016.

WESTERENG, B. et al. The Putative Endoglucanase PcGH61D from Phanerochaete chrysosporium Is a Metal-Dependent Oxidative Enzyme that Cleaves Cellulose. v. 6, n. 11, 2011.

WESTERENG, B. et al. Enzymatic cellulose oxidation is linked to lignin by long-range electron transfer. Scientific Reports, v. 5, n. December, p. 1-9, 2015.

WONG, D. W. S. Structure and Action Mechanism of Ligninolytic Enzymes. Albany: Springer US, 2009. v. 157

YOSHIDA, M. et al. Differential transcription of $\beta$-glucosidase and cellobiose dehydrogenase genes in cellulose degradation by the basidiomycete Phanerochaete chrysosporium. FEMS Microbiology Letters, v. 235, n. 1, p. 177-182, 2004.

YU, R. J.; SCOTT, E. J. V. Oligosaccharide aldonic acids and their topical use.United States, 2002.

ZÁMOCKY, M. et al. Cellobiose Dehydrogenase - A Flavocytochrome from WoodDegrading, Phytopathogenic and Saprotropic Fungi. Current Protein \& Peptide Science, v. 7, n. 3, p. 255-280, 2006.

ZÁMOCKY, M. et al. Cloning, sequence analysis and heterologous expression in Pichia pastoris of a gene encoding a thermostable cellobiose dehydrogenase from Myriococcum thermophilum. Protein Expression and Purification, v. 59, n. 2, p. 258-265, 2008.

ZAMOST, B. L.; NIELSEN, H. K.; STARNES, R. L. Thermostable enzymes for industrial applications. Journal of Industrial Microbiology, v. 8, n. 2, p. 71-81, 1991.

ZHUANG, X. et al. Liquid hot water pretreatment of lignocellulosic biomass for bioethanol production accompanying with high valuable products. Bioresource Technology, v. 199, p. 68-75, 2016. 


\section{APÊNDICE A - SEQUÊNCIAS UTILIZADAS PARA CONSTRUÇÃO DA ÁRVORE FILOGENÉTICA}

Tabela 6 - Dados das sequências de aminoácidos codificando diversas CDHs utilizadas na construção da árvore filogenética.

\begin{tabular}{|c|c|c|c|c|c|c|c|}
\hline Organismo & Filo & GenBank & Número de acesso & $C y t \mathrm{c}$ & GMC_N & GMC_C & $\mathrm{CBM}$ \\
\hline \multicolumn{8}{|c|}{ Classe I (basidiomicetos) } \\
\hline Athelia rolfsii & $\mathrm{B}$ & GI32395290 & AAO64483.1 & $26-188$ & $233-514$ & $632-760$ & - \\
\hline Phanerochaete chrysosporium & $\mathrm{B}$ & GI1279638 & CAA61359.1 & 24-199 & $234-506$ & $633-761$ & - \\
\hline Trametes versicolor & $\mathrm{B}$ & GI2739491 & AAC50004.1 & $25-195$ & $230-502$ & $629-757$ & - \\
\hline Pycnoporus_cinnabarinu & $\mathrm{B}$ & & $A D \times 41688.1$ & $6-177$ & $212-494$ & $611-739$ & - \\
\hline \multicolumn{8}{|c|}{ Classe IIA (ascomicetos com CBM) } \\
\hline Neurospora crassa & A & GI85080721 & XP_956591.1 & $30-220$ & $253-554$ & $647-782$ & $797-825$ \\
\hline Colletotrichum graminicola & A & GI310796933 & EFQ32394.1 & $34-222$ & $270-571$ & $664-800$ & $815-843$ \\
\hline $\begin{array}{l}\text { Thermothelomyces thermophila } \\
\text { ATCC } 42464\end{array}$ & A & GI3319315 & XP_003663382.1 & $29-218$ & $251-553$ & $646-781$ & $796-824$ \\
\hline Thielavia terrestris & A & & AEO69014.1 & $31-220$ & $253-554$ & $648-783$ & $798-826$ \\
\hline \multicolumn{8}{|c|}{ Classe IIB (ascomicetos sem CBM) } \\
\hline Aspergillus flavus NRRL3357 & A & GI238502313 & XP_002382390.1 & $81-269$ & $304-605$ & $716-850$ & - \\
\hline Aspergillus oryzae RIB40 & A & GI169775671 & XP_001822302.1 & $31-219$ & $254-555$ & $648-782$ & - \\
\hline Aspergillus terreus NIH2624 & A & GI115385497 & XP_001209295.1 & $31-219$ & $253-466$ & $587-720$ & - \\
\hline Aspergillus clavatus & A & GI121717196 & XP_001276037.1 & $31-219$ & $254-555$ & $648-783$ & - \\
\hline Aspergillus fumigatus Af293 & A & GI71002832 & XP_756097.1 & $31-231$ & $265-567$ & $662-796$ & - \\
\hline Aspergillus fumigatus $A 1163$ & A & GI159130152 & EDP 55266.1 & $31-231$ & $265-567$ & $662-796$ & - \\
\hline $\begin{array}{l}\text { Thermothelomyces thermophila } \\
\text { ATCC } 42464\end{array}$ & A & & XP_003664543.1 & $30-218$ & $249-549$ & $644-778$ & - \\
\hline Thielavia terrestris NRRL 8126 & A & GI 11521487 & XP_003650940.1 & $30-217$ & $249-549$ & $644-779$ & - \\
\hline Pyrenophora teres $f$. teres & A & GI311332074 & EFQ'95829.1 & $24-202$ & $245-541$ & $687-752$ & - \\
\hline Aspergillus fischeri NRRL 181 & A & GI119497843 & XP_001265679.1 & $28-203$ & $247-545$ & $682-754$ & - \\
\hline Aspergillus fumigatus Af293 & A & GI70988801 & XP_749254.1 & $28-203$ & $247-545$ & $651-754$ & - \\
\hline Aspergillus clavatus NRRL1 & A & GI121711118 & XP_001273175.1 & $28-203$ & $244-542$ & $647-751$ & - \\
\hline Aspergillus niger CBS 513.88 & A & GI145256128 & XP_001402432.1 & $28-204$ & $245-478$ & $655-725$ & - \\
\hline Botrytis cinerea & A & GI154317673 & XP_001558156.2 & $27-203$ & $240-535$ & $639-757$ & \\
\hline
\end{tabular}

Fonte: Arquivo próprio.

Nota: n/m: não mencionado

A: Ascomicetos

B: Basidiomicetos

As regiões de aminoácidos em que se encontram os domínios CYT (Cyt c), DH (GMC_N e GMC_C) e CBM (quando presente) também estão indicadas. 
Figura 30 - Alinhamento das sequências de aminoácidos das CDHs que apresentaram maior similaridade com a M77CDH

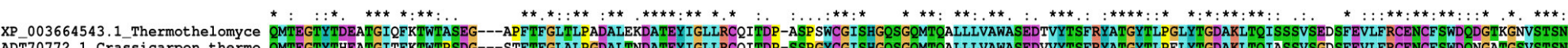

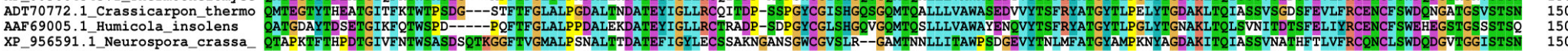

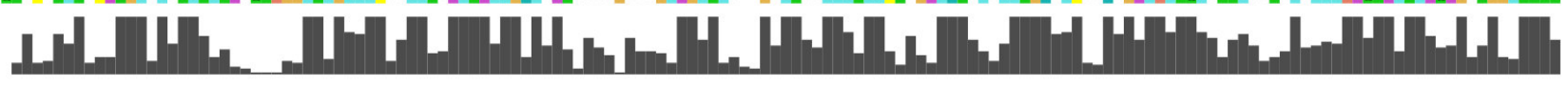

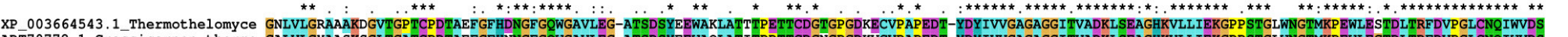

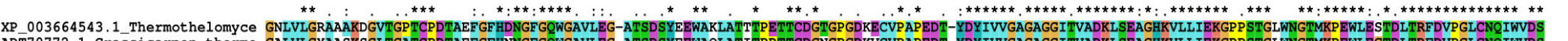

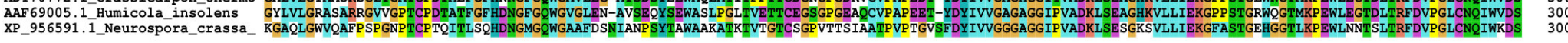

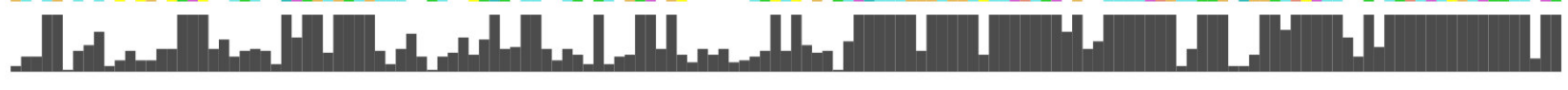

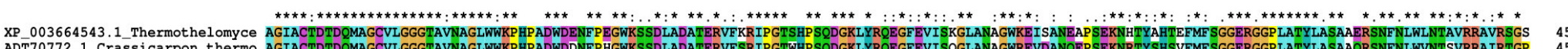

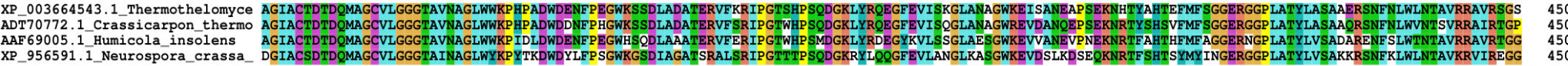

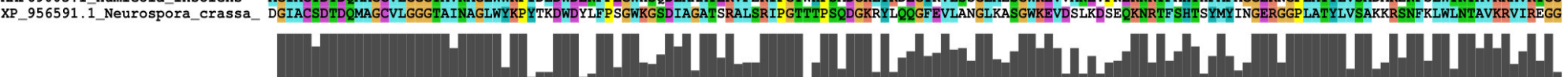

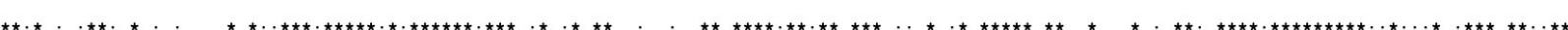

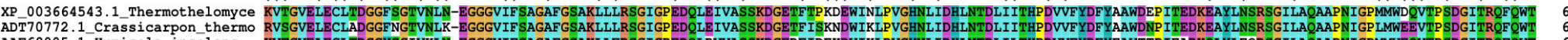

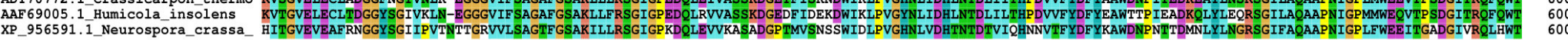

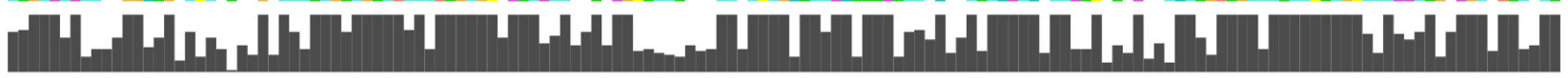

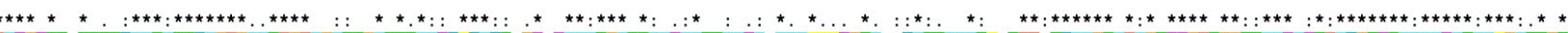

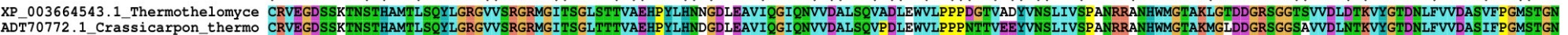

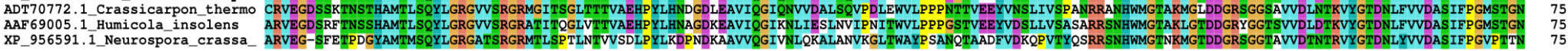

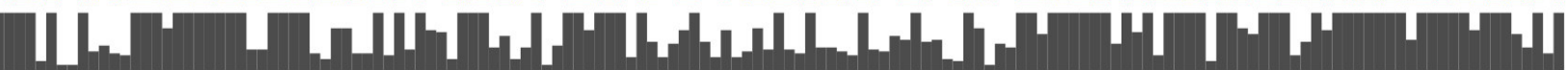

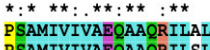

XP 003664543.1 Thermothelomyce

AAF69005.1_Humicola_insolens PSAMIVIAAEQQAAERTLKLRK---- - IIIT.

Fonte: Arquivo próprio. 


\section{APÊNDICE B - CURVAS DA CINÉTICA ENZIMÁTICA UTILIZANDO MÉTODOS COLORIMÉTRICOS.}

Figura 31 - Curvas de cinética enzimática da M77CDH utilizando celobiose como substrato e DCIP.
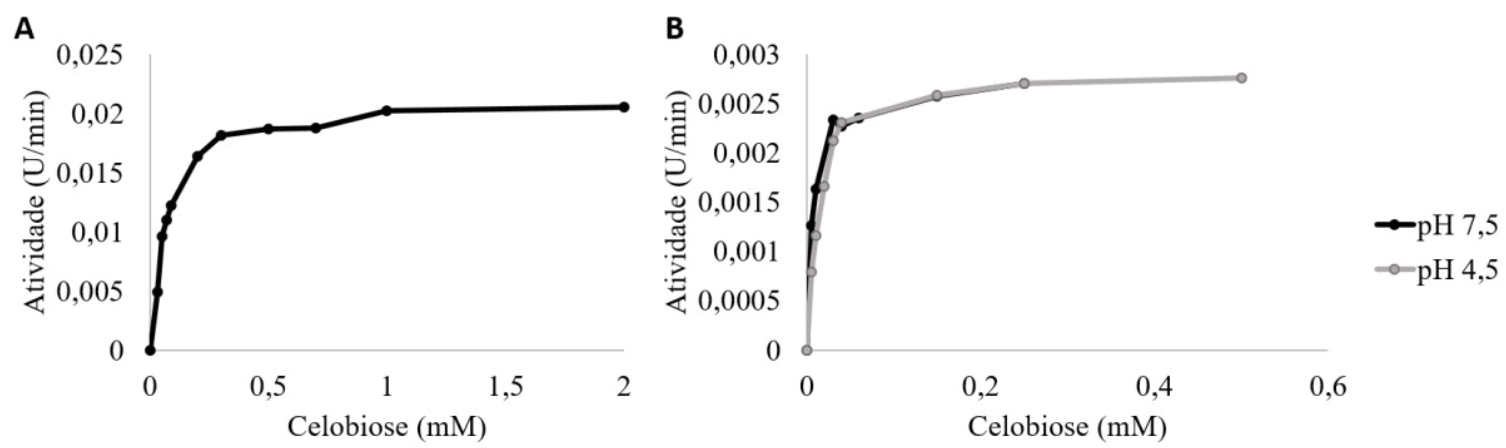

Fonte: Arquivo próprio.

Nota: A: Curva de cinética utilizando DCIP como aceptor de elétrons.

B: Curva de cinética utilizando Cyt $c$ como aceptor de elétrons.

Os desvios não excederam $5 \%$. 


\section{APÊNDICE C - CÁLCULOS DA ATIVIDADE ENZIMÁTICA DA M77CDH COM DIFERENTES ACEPTORES DE ELÉTRONS}

O cálculo de atividade de M77CDH é realizado através do decréscimo na absorbância do DCIP ou aumento da absorbância do citocromo $c$ (de coração de cavalo) quando adicionada à M77CDH. O comportamento da descoloração do DCIP ou mudança de cor do citocromo $c$ está indicado na Figura 32, juntamente com a equação da regressão linear da região linear (até 3 min de reação). O coeficiente angular da equação de regressão linear foi utilizado para os cálculos de atividade (quando não fosse possível obter essa curva, somente valores pontuais ao final do tempo de reação foram utilizados para o cálculo, e subtraiu-se de uma condição inicial sem a presença da enzima). Logo, os cálculos de atividade envolviam a Lei de Lambert-Beer:

$$
A b s=\varepsilon . l . c
$$

Sendo "Abs" o valor do coeficiente angular da curva de regressão linear (1/min), " $\varepsilon$ " o coeficiente de extinção molar do $\operatorname{DCIP}\left(6,8 \mathrm{mM}^{-1} \cdot \mathrm{cm}^{-1}\right)$ ou do citocromo $c\left(19,6 \mathrm{mM}^{-1} \cdot \mathrm{cm}^{-}\right.$ 1) (BAMINGER et al., 2001; CANEVASCINI; BORER; DREYER, 1991), "l” o caminho ótimo $(0,526 \mathrm{~cm})$ e "c" a concentração do DCIP/citocromo $c(\mathrm{M})$. Então:

$$
c=\frac{A b s}{\varepsilon . l}(\mathrm{mM} \mathrm{DCIP} / \mathrm{min})
$$

Multiplicando o valor de "c" por 1000 para ajustar a unidade para $\mu \mathrm{M} / \mathrm{min}$, e considerando o volume lido no espectrofotômetro de $200 \mu \mathrm{l}$ :

$$
\text { Atividade }=\frac{c * 1000 * 0,2 \mathrm{~mL}}{1000 \mathrm{~mL}}\left(\frac{\mu \mathrm{mol} D C I P}{\min }\right)
$$

Considerando o valor da alíquota de enzima utilizada na reação $(5 \mu L)$, ou da concentração de enzima $(0,55 \mathrm{mg} / \mathrm{ml})$ :

$$
\begin{gathered}
\text { Atividade volumétrica }=\frac{\text { Atividade }}{5 \cdot 10^{-3} \mathrm{~mL}}\left(\frac{\mu \mathrm{mol} D C I P}{m L . \text { min }}\right) \\
\text { Atividade específica }=\frac{\text { Atividade } * 1 \mathrm{~mL}}{5 \cdot 10^{-3} \mathrm{~mL} * 0,55 \mathrm{mg}}\left(\frac{\mu m o l \text { DCIP }}{\mathrm{mg} \text { enzima. } \min }\right)
\end{gathered}
$$


Figura 32 - Curvas exemplificando a metodologia utilizada para calcular a atividade enzimática da M77CDH.
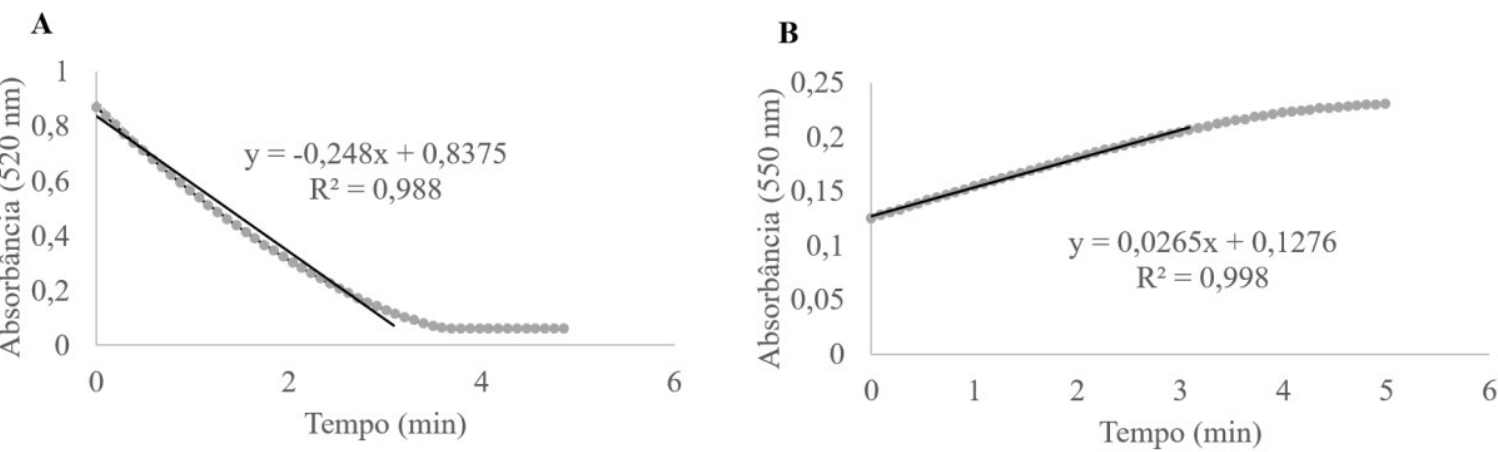

Fonte: Arquivo próprio.

Nota: A: Redução do DCIP (observado pelo decréscimo da absorbância) pela CDH na presença de $50 \mathrm{mM}$ de celobiose em tampão acetato de sódio $\mathrm{pH} 5,5$ a $30^{\circ} \mathrm{C}$. A linha de tendência foi traçada somente na região linear do decréscimo de absorbância e o coeficiente angular foi utilizado para os cálculos de atividade da M77CDH.

B: Redução do citocromo $c$ (de coração de cavalo) (observado pelo aumento da absorbância) pela CDH na presença de $10 \mathrm{mM}$ de celobiose em tampão citrato-fosfato-glicina $0,1 \mathrm{M}, \mathrm{pH} 6,0$, a $30^{\circ} \mathrm{C}$.

A linha de tendência foi traçada somente na região linear do acréscimo de absorbância e o coeficiente angular foi utilizado para os cálculos de atividade da M77CDH. 


\section{APÊNDICE D - CURVA PADRÃO DNS PARA DETERMINAÇÃO DE AÇÚCAR REDUTOR}

Utilizando a equação fornecida pela curva padrão (Figura 33A):

$$
\text { Abs }=0,0147 * \text { Massa glicose }-0,2057
$$

Figura 33 - Curvas padrão utilizadas no trabalho.

A

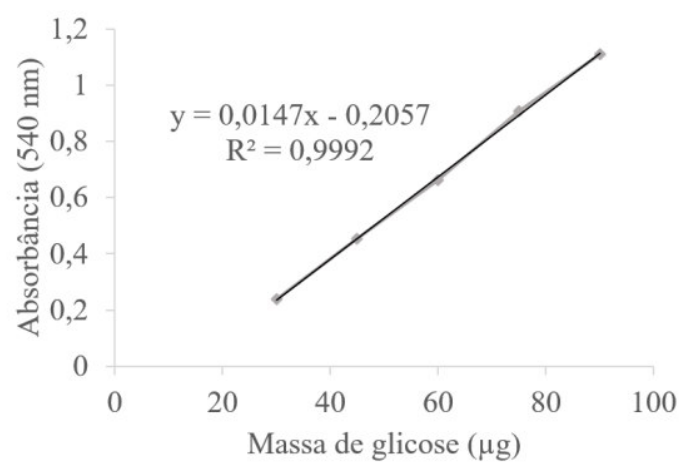

B

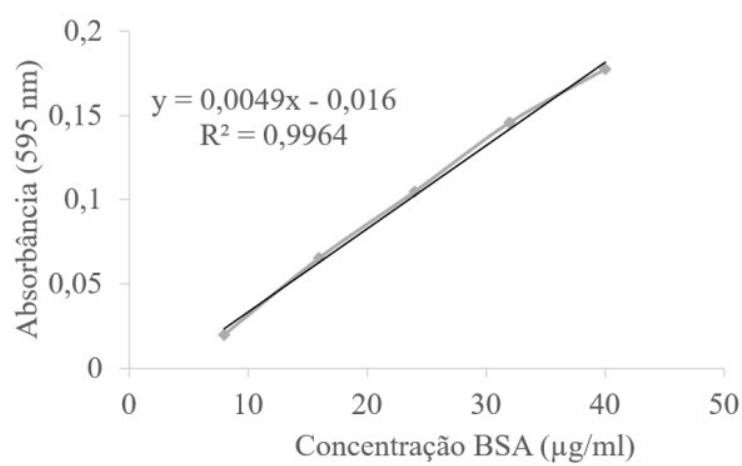

Fonte: Arquivo próprio.

Nota: A: Curva padrão do DNS utilizada para detecção da concentração de açúcares redutores presentes no meio de cultivo.

B: Curva padrão de BSA para ensaio de Bradford utilizado para deteç̧ão da concentração de proteínas.

Encontra-se o valor de massa de açúcar redutor (glicose em $\mu \mathrm{g}$ ). Então, divide-se esse valor pelo volume da alíquota utilizada no ensaio (e multiplica-se pelo fator de diluição, quando necessário).

$$
\begin{aligned}
& \frac{\text { Massa glicose }}{\text { volume alíquota da amostra }(\mu \mathrm{l})} * \text { fator de diluição } \\
& =\text { Concentração açúcar redutor na amostra }\left(\frac{\mathrm{g}}{\mathrm{L}}\right)
\end{aligned}
$$

Para a determinação concentração de proteína, utilizou-se a equação fornecida pela curva padrão (Figura 33B):

$$
\text { Abs }=0,0049 * \mathrm{C}-0,016
$$

Encontra-se o valor de C (concentração de proteína em $\mu \mathrm{g} / \mathrm{ml})$, multiplicando-se pelo volume da amostra lida no espectrofotômetro $(200 \mu \mathrm{l})$ :

$$
\mathrm{C} * 0,2 \mathrm{ml}=\text { massa de proteína na alíquota da amostra }
$$

Porém, essa massa de proteína corresponde a massa presente em x volume de amostra utilizada para realizar o ensaio de Bradford. Então, divide-se essa massa de proteína pelo volume da alíquota utilizada no ensaio, tem-se a concentração de proteína na amostra original:

$$
\frac{\text { Massa proteína }}{\text { volume alíquota da amostra }(\mu \mathrm{l})}=\text { Concentração proteína na amostra }\left(\frac{\mathrm{g}}{\mathrm{L}}\right)
$$




\section{ANEXO A - ESTRUTURA CDH E SEUS DOMÍNIOS}

Figura 34 - Estrutura do FAD e heme b (ou haem b) e suas respectivas localizações nos domínios DH e CYT.

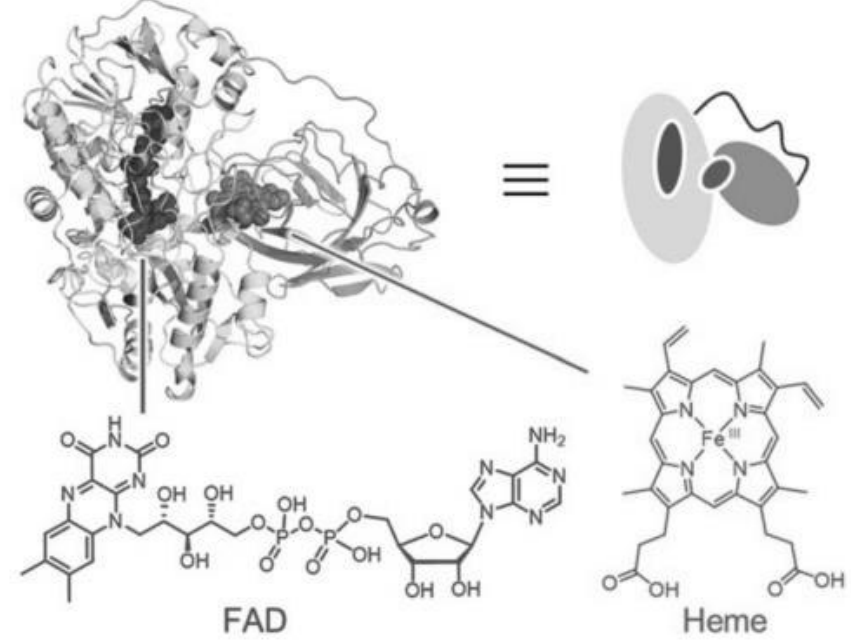

Fonte: (HARADA et al., 2017).

Nota: $\mathrm{Na} \mathrm{CDH}$ o elemento Fe contido no heme está complexado com uma metionina e uma histidina (COX et al., 1992). 


\section{ANEXO B - MEIOS DE CULTURA}

- Para a manutenção da linhagem

O meio utilizado para manutenção do cultivo de fungos é meio mínimo, pH 6,5, composto por $1 \mathrm{mg} / \mathrm{ml}$ de piridoxina, $1 \%$ de glicose, $50 \mathrm{ml}$ de solução de sais $(12 \%$ de $\mathrm{NaNO}_{3}, 1,4 \%$ de $\mathrm{KCl}, 1,4 \%$ de $\mathrm{MgSO}_{4} .7 \mathrm{H}_{2} \mathrm{O}$ e 3,4\% de $\mathrm{KH}_{2} \mathrm{PO}_{4}$ ), $1 \mathrm{ml}$ de solução de elementos traço $\left(2,2 \%\right.$ de $\mathrm{ZnSO}_{4} .7 \mathrm{H}_{2} \mathrm{O}, 1,1 \%$ de $\mathrm{H}_{3} \mathrm{BO}_{3}, 0,5 \%$ de $\mathrm{MnCl}_{2} .4 \mathrm{H}_{2} \mathrm{O}, 0,5 \%$ de $\mathrm{FeSO}_{4} .7 \mathrm{H}_{2} \mathrm{O}, 0,16 \%$ de $\mathrm{CoCl}_{2} .5 \mathrm{H}_{2} \mathrm{O}, 0,16 \%$ de $\mathrm{CuSO}_{4} .5 \mathrm{H}_{2} \mathrm{O}, 0,11 \%$ de $\mathrm{Na}_{2} \mathrm{MoO}_{4} .4 \mathrm{H}_{2} \mathrm{O}$ e $5 \%$ de $\mathrm{Na}_{2}$ EDTA) para o $1000 \mathrm{ml}$ de meio.

- Para expressão de proteínas

Para a expressão heteróloga de proteínas foi utilizado $500 \mathrm{ml}$ de meio mínimo especificado no item 0 , suplementado com $3 \%$ de maltose. Foram inoculados $10^{7}-10^{8}$ esporos de A. nidulans recombinante para a M77CDH e o cultivo foi incubado a $37{ }^{\circ} \mathrm{C}$ por 2 dias em placas de Petri em condições estacionárias. O micélio foi separado do sobrenadante por filtração com membrana Miracloth.

\section{- MANDELS}

O meio Mandels (200 ml) foi composto de 0,06 $\mathrm{g}$ de ureia, 0,15 $\mathrm{g}$ de peptona, 0,05 $\mathrm{g}$ de extrato de levedura, 0,28 g de (NH4)2SO4, 0,4 g de KH2PO4 e 0,06 g de CaCl2, e solubilizados em $200 \mathrm{ml}$ de água destilada.

- SOC

O meio SOC foi composto de $20 \mathrm{~g} / \mathrm{L}$ de triptona, $5 \mathrm{~g} / \mathrm{L}$ de extrato de levedura, 10 $\mathrm{mM}$ de $\mathrm{NaCl}, 2,5 \mathrm{mM}$ de $\mathrm{KCl}, 20 \mathrm{mM}$ de $\mathrm{MgCl} 2$ e $20 \mathrm{mM}$ de glicose.

$-\mathrm{LB}$

O meio LB foi composto de $1 \%$ de triptona, $0,5 \%$ de extrato de levedura, $1 \%$ de $\mathrm{NaCl}, 2 \%$ de ágar e ajustou-se o $\mathrm{pH}$ para 7,0. 